\title{
（25） 転妒炉内の脱リン反応特性
}

\begin{abstract}
新日本製鐵泽製鐵所 $\bigcirc$ 原田俊哉 柳沢 健 下村健介磯平一郎
日鐵プラント設計村上義男
\end{abstract}

\section{1. 緒言}

転炬炬内の脱リン反応解析は，従来から重回㷌分析による 手法が多く用いられてきたが，充分な知見は得られていない。

本報では，活量表現による平衡式を用いて解析を行ない， 脱リン能に対する[C]の影響, ならびに上底吹転炉における 鋼浴贊拌の影響について明らかにした。

\section{2. 操業条件}

解析には，底吹流量可変の上底吹転炉 L B E プロセスの実操 業データを用いた。底吹流量は, 低中炭材( [C] $\leq 0.30 \%$ ) $0.10 \mathrm{Nm}^{3} / \mathrm{T} \cdot \mathrm{min}$, 高炭材 ( $\left.[\mathrm{C}]>0.30 \%\right) 0.03 \mathrm{Nm}^{3} / \mathrm{T} \cdot \mathrm{min}$ とし ている。また以下の解析には，普通溶銑と脱リン溶銑を併用した。

\section{3. 解析方法}

脱リン反応式は(1)式とおき，活量表現をした(2)式中の $\mathrm{K}^{\prime}$ を 見かけの平衡定数として，脱リン能を評価した。

$$
\begin{aligned}
& 2 \mathrm{P}+5 \mathrm{FeO}=\mathrm{P}_{2} \mathrm{O}_{5}+5 \mathrm{Fe} \\
& \log \frac{\mathrm{a}_{\mathrm{P}_{2} \mathrm{O}_{5}}}{\mathrm{a}_{\mathrm{P}}^{2}}=5 \log \mathrm{a}_{\mathrm{FeO}}+\frac{5250}{\mathrm{~T}}+\mathrm{K}^{\prime}
\end{aligned}
$$

\section{4. 解 析 結 果}

$\mathrm{K}^{\prime}$ を吹止〔C]に対してプロットすると，高炭域ほど $\mathrm{K}^{\prime}$ は低下 している。(Fig.1) これは，高炭域ではスラグと鋼浴の酸素 活量差を大きくしているためと考えられる。低炭域で強穓拌を 行なうと, [C]-( T.Fe)の関係が変化し, その結果, Fig.2の ように見かけの脱りン能は向上する。また，高炭域においては K'のばらつきが大きいが，（T.Fe）の低下に伴い， スラグと鋼 浴の酸素活量差が縮まるので, Fig. 3 に示すような相関が生じ る。この関係を基に，高炭域での（T. Fe )と（P)/[P]の関係を， 計算によって求めたのが Fig. 4 である。塩基度一定の場合, ( T. Fe ) $10 \%$ 前後までは脱リン能が高いが，それ以下では急激 に低下する。また ( T. Fe )を $10 \%$ 以上に増加させても， $\mathrm{K}^{\prime}$ が低 下寸るため, 低炭域ほど大きな向上は期待できない。

\section{5. 結}

活量表現を用いた脱りン平衡式により，低炭から高炭にわたる脱り ン特性に対する統一的な解釈を得た。これによって, 鋼浴䅐汼の脱り ン能に及ぼす影響, ならびに高炭域での脱リン特性が説明され，本法 が脱りン反応解析の精度向上に有効な手段であることが示された。
（参考文献） 1. 後滕ら鉄鋼協会第 107 回講演大会

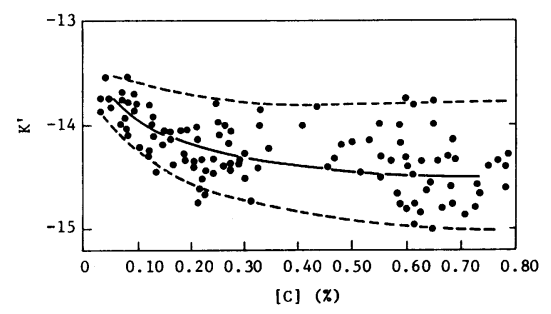

Fig. 1 Relationship between apparent phosphorous equilibrium constant $\mathrm{K}^{\prime}$ and carbon content.

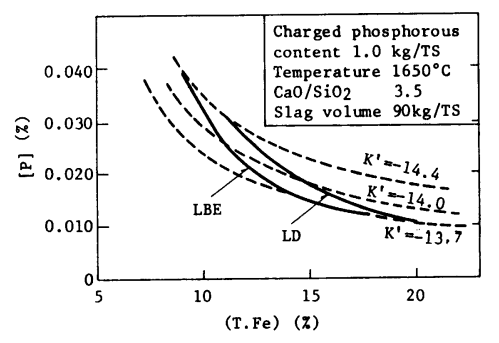

Fig. 2 Relationship between calculated phosphorous content in metal and iron content in slag in LD and LBE process.

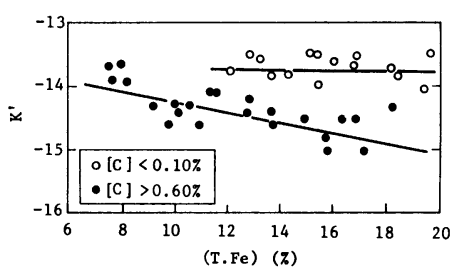

Fig. 3 Influence of iron content in slag on apparent phosphorous equilibrium constant ' $\mathrm{K}^{\prime}$ in low and high carbon ranges.

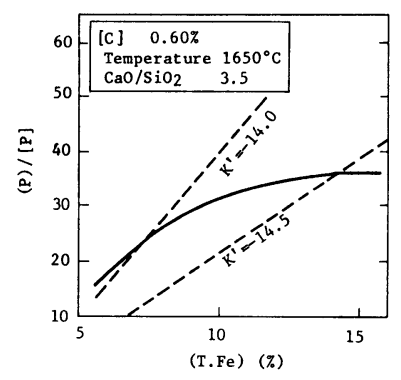

Fig. 4

Relationship between phosphorous distribution ratio and iron content in slag in high carbon range. 
新日本製鐵株 君津製鐵所 ○後藤裕規 原田俊哉 山田容三 杉原弘祥 中央研究本部君津技術研究部向井達夫

\section{1. 緒}

転炬の上底吹化，溶銑脱リン処理による転炬内スラグ量の大幅な低減等により，転炬吹鍊は大きく变 化している。これらの転师吹鍊における脱リン反応を統一的に比較検討するために,スラグメタルの 活量計算を基本とした熱力学的検討をおこなった。

\section{2. 検 封 方 法}

君津製鐵所第一製鋼工場 $250 \mathrm{t}$ 転炉において, 上吹吹鍊と上底吹吹鍊の比較，低炭素鋼と高炭素鋼の 比較を，第二製鋼工場 $300 \mathrm{t}$ 転炉において，上吹吹鍊と上底吹吹鍊の比較，脱リン溶銑を用いたスラグ 量の少ないレススラグ吹鍊の比較をおこなった。

脱リン反応と脱リン平衡式は(1)式, (2)式で記述される。(2)式の計算に必要な活量俰数
$2[\mathrm{P}]+5(\mathrm{FeO})=\left(\mathrm{P}_{2} \mathrm{O}_{5}\right)+5 \mathrm{Fe}$
(1)
$\log \left(\mathrm{a}_{\mathrm{P}, \mathrm{O}_{\mathbf{5}}} / \mathrm{a}_{\mathrm{P}}{ }^{2} \cdot \mathrm{a}_{\mathrm{FeO}}{ }^{5}\right)=\mathrm{A} / \mathrm{T}+\mathrm{B}$

の計算式ならびに計算值は, Turkdogan et. ${ }^{1)}$, 大谷 ${ }^{2)}$, 山田 ${ }^{3)}$ の結果を適用した。

3. 結果およひ考察

（1）スラクの脱リン能を支配する $\mathrm{FeO} の$ 活量： $\mathrm{a}_{\mathrm{FeO}}$ は，上吹吹鍊，上底吹

吹鍊，レススラグ吹鍊において，Fig.1に示すようにスラグ成分に応じて 変化している。すなわち, $\mathrm{a}_{\mathrm{FeO} 0}$ は, 上底吹化によりスラグの ( T. Fe ) と ともに低下している。また，レススラグ吹鍊で（ T. Fe）と塩基度を上 昇させた場合， $\mathrm{a}_{\mathrm{FeO}}$ の上昇はほとんどみられない。鋼中酸素がレス スラク吹鍊においても特に変化がないことからも活量の評価の妥当 性が認められる。

（2）活量表現を用いた脱リン平衡式で整理するとFig. 2 に示すとおり上吹 吹鍊，上底吹吹鍊，レススラグ吹鍊のデータはほぼ同一の直線上にのり，み かけの脱リン平衡式は, $\log \left(a_{\mathrm{P}_{2} \mathrm{O}_{5}} / \mathrm{a}_{\mathrm{P}}{ }^{2}\right)=$ $5 \log \mathrm{a}_{\mathrm{FeO}}+5250 / \mathrm{T}+\mathrm{K}^{\prime}$ で統一的に表現さ れる。スラグ成分の変化による脱りン反応 におよぼす効果と比較すると底吹の㘔拌効 果は小さいことがわかる。

(3) 高炭素域のみかけの脱リン平衡は低 炭素域と比較するとFig. 3 に示すとおり低 下している。これは鋼浴とスラグの酸素ポ テンシャルに差があり，高炭素域ほど鋼浴 の酸素ポテンシャルがスラグのそれより低 くなっているためと考えられる。

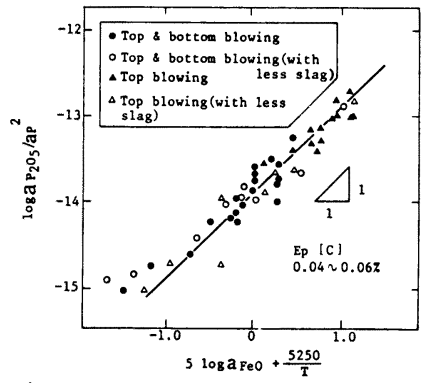

Fig. 2

Phosphorous distribution ratio by calculating activities of constituents of metal and slag.

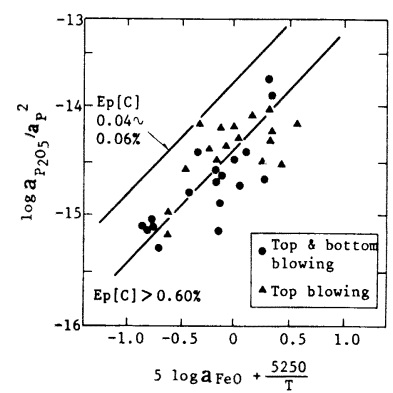

Fig. 3

Influence of carbon contents on phosphorous distribution ratio in terms of activities calculated.

\section{（参考文献）}

1) E. T. Turkdogan et. : JISI $176(1954)$ P 59

2) 大谷正康：鉄治金熱力学P 218 (日刊工業新聞社)

3）山田健三他：鉄と鋼65（1979）S674

4) John F. Elliott et. :Journal of Metals (1955) P 1129 


\section{（253）上下吹き転炉における底吹きノズルの開発}

日本鋼管 福山製鉄所 ○小林 日登志 丹村 洋一

\section{1. 緒言}

従来 福山製鉄所では、上下吹き転炉の底吹きノズルとし て、Mg O-C 耐火物に多数の細孔を設けたMHP，ズル (Multiple Hole Plug )を使用してきた。 ところが、底 吹きガスとして $\mathrm{CO}_{2}$ を用いる事から 前報で報告した様に 溶損が激しい。そこで 新ノズルとして MHP - D タイ プ ( MH P - Double F low) 開発し、その溶損を 抑制す る事とした。本報では、 $\mathrm{MH}$ P - D タイプの使用状況及 びその効果について報告する。

2. 構造 及び 操業方法

従来の $\mathrm{MHP}$ ノズルは、 $\mathrm{CO}_{2}, \mathrm{Ar}, \mathrm{N}_{2}$ を各細孔いづれ も同一のガス種でしか底吹き出来ず、その結果 $\mathrm{CO}_{2}$ を底吹 きした場合 ノズルとその周辺の耐火物とのメジ部が 先行 溶損される問題が生じた。そこで Fig．1.に示す様に、 外周系統と内側系統に分け 各々異種のガス種を底吹き出来 る様にし、外周系統には $\mathrm{Ar}, \mathrm{N}_{2}$ の不活性ガスを主体に流 す事とした。㕛外周系統は、Fig．2.に示す様に、ジェ ッティング条件を 小流量で満足する様に内側の細孔径よ ク小径の細孔とした。底吹きパターンの一例をF ig . 3.に 示す。内側系統は $\mathrm{CO}_{2}$ を主体に底吹きし 流量のコントロ ールを行い、外周系統は、前述した様に $\mathrm{Ar}, \mathrm{N}_{2}$, をジェッ ティング条件を満足する流量で一定流量の底吹きを実施し ている。

\section{3. 効果}

ノズルの溶損速度は、従来の MHPに比較し 約 $15 \%$ 程度 減少し、メジ部の溶損状況は、従来 ノズル中央に比較し、 約 $1000 \mathrm{~m}$ 程度 凹状になっていたのに対し、MH P - D タイプでは、その先行溶損が殆んど認められず平担な溶損状 況となった。

現在 福山製鉄所のすべての転炬にこの新ノズルを適用 しており、最高 1600 回の寿命を確保している。

参考文献 (1) 高橋 5 ; 第 104 回鉄鋼協会講演会 S995
栗山 伸二 白谷 勇介

半明正之宮脇 芳治

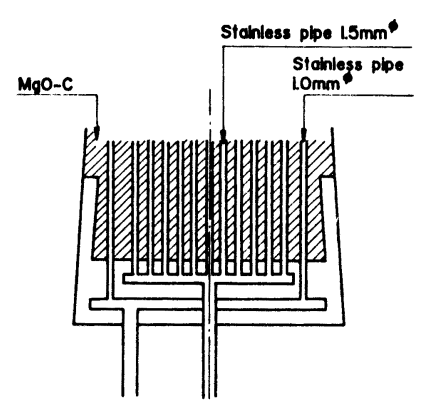

Fig. I. Crossectional diagram of MHP-D type.

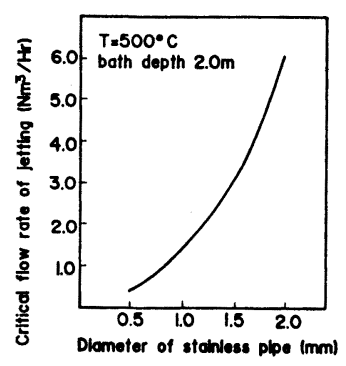

Fig.2. Relation between diameter of stainless pipe and critical flow rate of jetting.

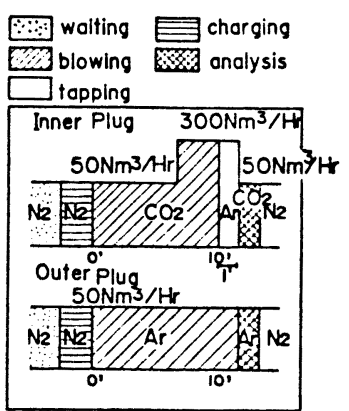

Fig.3. Bottom blowing pattern with MHP-D type. 
$84-\mathrm{S} 254$

\section{（254）底吹き枟炉羽口周辺の疑固鉄 の生成機檴}

川崎製鉄(株)技術研究所 ○岸本康夫 加藤葥英

\section{藤井笅也 坦生泰弘}

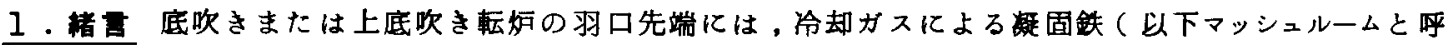

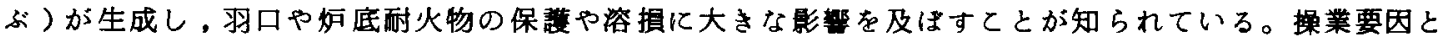
マッシュルームの形状についての報告も $2 ， 3$ 見られろが ${ }^{1)}$ 統一的な知見は得られていない。そてで今 回，コールド，ホットモデル実䍄を行うと共に，マッシュルームの生成熱収支モデルを作り，マッシュルー ムの生成機構の統一的な解明をはかった。

2.実駼方法 Fig.1亿示す䒾置を用いて，コールドモデル実験 を行った。単管または二重管羽口に供給する圧縮空気の冷却には 液体窒素を用いた。水温，ガス流量，ガス温度などが、マッシュル 一ム(水)の形状変化に及はす影旂を調べた。ホットモデル実䤅 では，2 重管羽口を鋼浴中に漫清し，内管に酸素，外管にクーラ ントを所定量流して，羽口周辺のマッシュルームの形状などを調べ た。

\section{3.実験結果とモデル計筆}

3.1 単管羽口の実䍄 管径 $8 \mathrm{~mm}$ ，ガス温度 $-180^{\circ} \mathrm{C}$ ，ガス

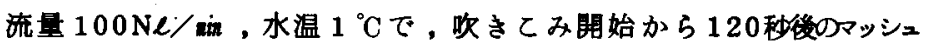
ルームの外観をPhoto1亿示す。羽口周りにはナードル状の水が 形成されている。Fig.2に，マッシュルーム望量Wと吹きとみ時間の 関係を示す。Wはマッシュルームの底部半径と高さを用いて円錐近 似で求めた。Wの增加速度は，氷温が低いはど大きい。

3.2 熱収支モデルの適用 マッシュルーム内に温度分布がない ものとすると，熱収支から以下の基礎式が得られる。

$\left\{\Delta \mathrm{H}+\mathrm{C}_{\mathrm{p} \ell}\left(\mathrm{T}_{\mathrm{b} \ell}-\mathrm{T}_{\mathrm{m}}\right)\right\} \frac{\mathrm{dw}}{\mathrm{dt}}=\dot{\mathrm{m}}_{\mathrm{g}} \mathrm{C}_{\mathrm{pg}}\left(\mathrm{T}_{\mathrm{og}}-\mathrm{T}_{\mathrm{ig}}\right)-k \mathrm{~s}_{\mathrm{bm}} \frac{\partial \mathrm{T}}{\partial \mathrm{Z}}-\mathrm{hS} \mathrm{tm}_{\mathrm{tm}}\left(\mathrm{T}_{\mathrm{b} \ell}-\mathrm{T}_{\mathrm{m}}\right)$

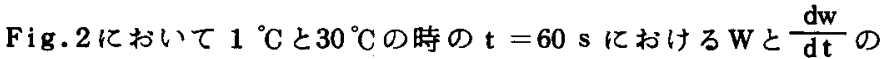
測定值を用いて，(1)式璂づいて $\mathrm{h}$ と $\mathrm{T}_{\mathrm{og}}$ 求めると， $\mathrm{h}=11.4$ $\left.\left(\mathrm{kw} / \mathrm{m}^{\circ} \mathrm{C}\right), \mathrm{T}_{\mathrm{og}}=-1680^{\circ} \mathrm{C}\right)$ が得られる。これらの值を用いてWの経 時変化を其出し，Fig.2 亿示した。 $120 \mathrm{~s}$ までは，水温が $5{ }^{\circ} \mathrm{C}$ と10 ${ }^{\circ} \mathrm{C}$ の場合にも寒測值と計算值ははは一致し，(1)式の熱収支モデル はコールドモデル実験結果を説明可能である。そこで，ホットモ デル実験結果にも本熱収支モデルを発展，適用した。

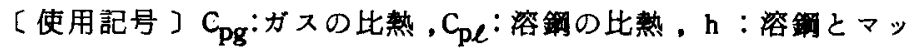
シュルームの間の熱层達係数, $\dot{\mathrm{m}}_{\mathrm{g}}$ :ガス質量流量, $\mathrm{S}_{\mathrm{bm}}$ :マッシュルーム の底部面積, $\mathrm{S}_{\mathrm{tm}}$ : マッシュルームの表面積, $\mathrm{T}_{\mathrm{b} \ell}$ : 溶鋼の温度, $\mathrm{T}_{\mathrm{ig}}$ : ガス温度， $\mathrm{T}_{\mathrm{m}}$ : マッシュルームの温度， $\mathrm{T}_{\mathrm{og}}$ : マッシュルームを出る時の ガス温度，W：マッシュルームの罆量，Z：羽口先端からの高さ， $\Delta \mathrm{H}$ ：凝固潜熱， $\boldsymbol{k}$ : 耐火物の熱层導度（全てM K S 单位） [参考文献]1）仲村 万，鉄と銅；67（1981）, S873

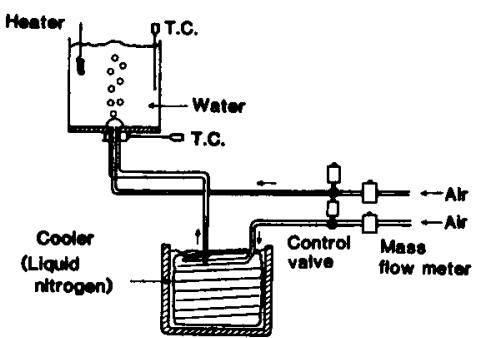

Fig.1. Sohomatic diagram of

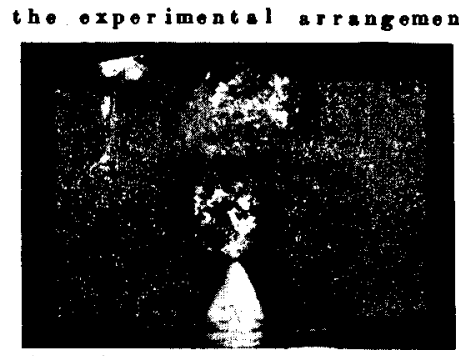

Photo 1. Gas flow through ice mushroom $\times 10^{-3}$

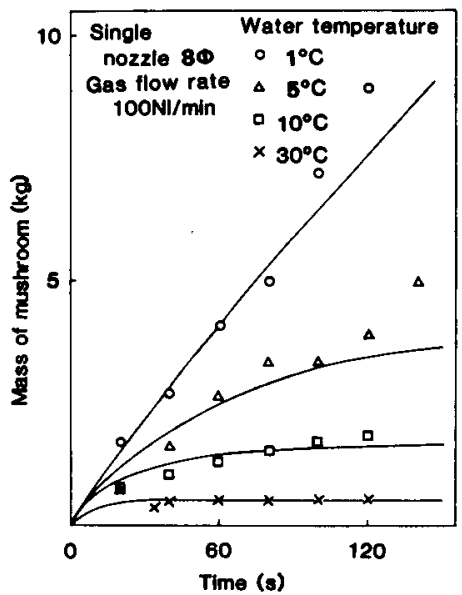

Fig.2 Change in mass of mushroom during blowing 


\section{（255）転炉底欦羽口測温による溶損量推定に関する一検討}

新日本製鐵君津製鐵所橙崎誠治宦下永 ○伊藤䓔宏木内啓嗣

\section{I - 緒言}

熱電対を利用して底吹羽ロ溶損量を推定する方法は、種々提唱されているが、著者らは、特にオンラ インで简便かつ、精度良く溶損量を推定する方法の開発に取り組み、実用化の見通しが得られたのて、 その状況につんて述へる。

\section{II . 計算検討結果}

羽ロレンカ温度から溶損量を推定するには、レンガ内温度分布が、一意に決まれば良い。したがって 一次元非定常伝熱計算により、炉内温度等、レンガ内温度分布に影警を及汪すと考えられる要因につん て検討した。計算条件は、师内温度として矩形波を仮定し、溶鋼温度および実炬、空师時間を変化させ た。

(1) 炬立上げ後のレンガ蓄熱レベル変化の影䒜：一定の温度変化の繰り 返しを以って、準定常状態とみなすとすると、Fig-1に示す様に、稼 動面から $2000 \mathrm{~mm}$ 梁では、約 30 ヒートで準定常状態に達する。した がって、炬立上げ後の影慗は、炉寿命全体の内わずかの部分である。 以下、この繰り返し見られる温度変動の幅を温度変動幅と呼ぶ。

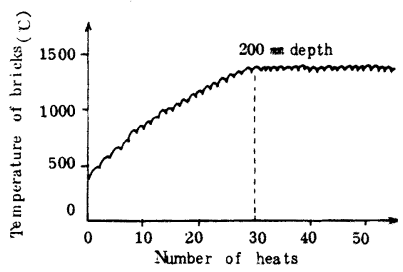

(2) 炬内温度变化の影撆：レンカ内温度分布は、Fig-2に示す様に溶鋼 温度の変化に伴い、ほほ平行移動するが、温度変動幅は、溶鋼温度変 化には、ほとんと依存しない。

（3）実炉、空炬時間変化の影整：レンガ内温度分布、温度変動幅共に、 通常の吹鍊時間程度ならば、実炉時間は、ほとんど影䇾がる。一方 空炉時間変化に上り、レンガ内温度分布、温度変動幅共に大をく変化 する。

以上の検討結果より、师の立上げ初期を除けば、各々の空炬時間に 対応した温度変動幅ブロフィールによりレンカ溶損量を推定でをるて とが予想される。

\section{III. 実機適用結果}

上述の温度変動幅プロフィールと羽ロレンガ測温結果から、羽 ロレンカ溶損量を推定した結果をFig-3に示す。各ヒート毎の推 定結果は、スラグコーティング等の影啓でバラッキを生ずるため こてては、前後数ヒートの推定結果を順次移動して平均をとり、 平滑化した。検尺による測定結果とは、ある一定の差を生ずるす のの溶損量の推移は、良く一致している。

\section{$N$. 結言}

羽ロレンガ測温結果を基に溶損量の推定を行なったとてろ、検 尺に上る測定結果とほほ良く一致し、羽口溶損管理に有効な方法 の一つであるてとが分かった。

参考文献 1) 例えば、永井ら：鉄と鋼、67（1981）S 808
Fig-1 Example of simulation

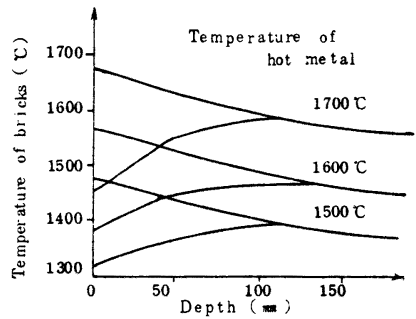

Fig-2 Heat pattern of bricks

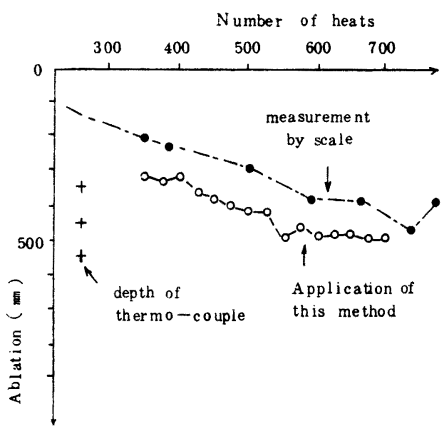

Fig-3 Example of application to LD - 0 B 
1. 緒 贯: 転炬の酸素底吹き羽口の保護に汎用されている炭化水素系のガス・液体に替るものとし

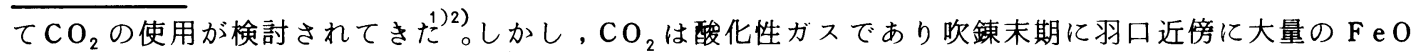
が生成する現象を抑制し得ず，羽口耐火物の化学的損傷が著しい欠点を有している゙。 そとで，還元性で あるC O ガスの羽口保護能を試験転炉を用いて調查した。

2 実験方法: 純度 $99 \%$ CO ガスを 5 底吹き転炉の羽口 1 本あるいは全羽口( 4 本) の外管に, 対 $\mathrm{O}_{2}$ 比 $10 \sim 20 \%$ の流量で導入した。羽口損耗が $\underline{\mathrm{C}}<0.02 \%$ Fe酸化吹鍊期に集中して進行する事実に鑑み, この吹鍊を 10 min 程度継続する羽口損耗強調吹鍊を行ない羽口および而火物の損耗量を測定した。また， 外管に不活性ガス $\left(\mathrm{N}_{2}\right)$ と共に微粉コークスを吹き込む吹鍊も行なった。

\section{3. 実験結果と考察： Fe酸化吹鍊時間と羽口耐火物損} 耗量の関係を Fig.1亿示す。損耗がFe酸化吹鍊に支配さ れているのが明らかであるが, COガスおよび $\mathrm{N}_{2}+\mathrm{C}$ 粉の 損耗抑制能はプロパンと同等以上であり，酸素底吹き羽 口の保護に還元性ガスの使用が有効であるのを示す。

Photo. 1 亿COガスを用いた際に形成されたマッシュルーム の組織を示す。気孔内面に豆の富化したセメンタイト層 パーライト風が認められ，

$\mathrm{CO}(\mathrm{g}) \rightarrow \mathrm{CO}($ ads $) \rightarrow \mathrm{C}($ ads $)+\mathrm{O}($ ads $) \cdots(1)$ の反応を介する $2 \mathrm{CO}(\mathrm{g}) \rightarrow \mathrm{C}(\mathrm{s})+\mathrm{CO}_{2}(\mathrm{~g}) \cdots(2)$ に上り生成する $\mathrm{C}(\mathrm{s})$ が火 点に送入される効果が羽口保護に有効であるととを示唆 する。乙れは， $\mathrm{N}_{2}$ にる C 粉送入の効果に対応する。 (2) 式の反応進行率を $\alpha$ として, 羽口近傍における反応お よび反応熱はFig.2 亿示すように

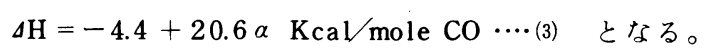

(2) 式による $\mathrm{C}(\mathrm{s})$ 析出反応が表面反応律速であり, 送入Co ガス量に依存しないととを考虑すると，COガス量の增大 と共に $\alpha$ が低下して吸熱量が低下するととになる。ての 予測は火点温度測定により確認され, 羽口近傍の $\mathrm{FeO}$ が $\mathrm{C}(\mathrm{s}), \mathrm{CO}(\mathrm{g})$ 亿より還元され羽口耐火物の化学的損傷が抑 制されるとの推測を車付けている。

全羽口にCOガスを使用した際の鋼中 $\underline{H}$ 值の低下はプロ パンを用いた場合に比較して著しく，また， $\underline{\mathrm{C}}-\underline{\mathrm{O}}$ ， $\underline{\mathrm{C}}-(\mathrm{T} \cdot \mathrm{Fe})$ の関係はプロパンの場合と差がなく, 十分に 実用に足る羽口保護ガスであるととを確認した。後者に ついては，Pcoの上昇にも拘らず低笛吹止が可能なとと を意味し興味深い。

文献 1)野崎他：鉄と鋼, 66 (1980)S241

2) M. Chastant et al :Rev. Métall., $7 \underline{8}(1981)$ p. 775

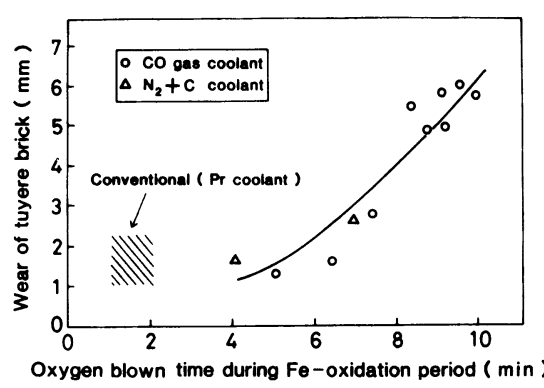

Fig. 1 Wear of tuyere brick with oxygen blown time for $\mathrm{CO}$ gas, $\mathrm{N}_{2}+\mathrm{C}$, and $\mathrm{Pr}$ coolant

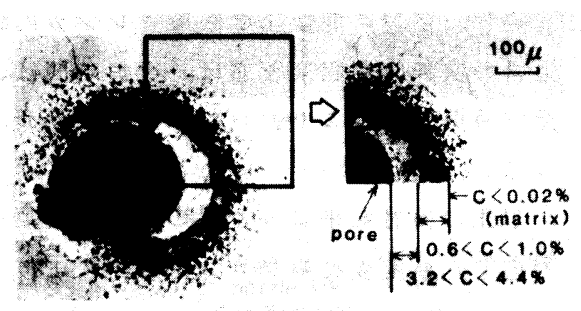

Photo. 1 Microstructure of mushroom formed with CO gas coolant

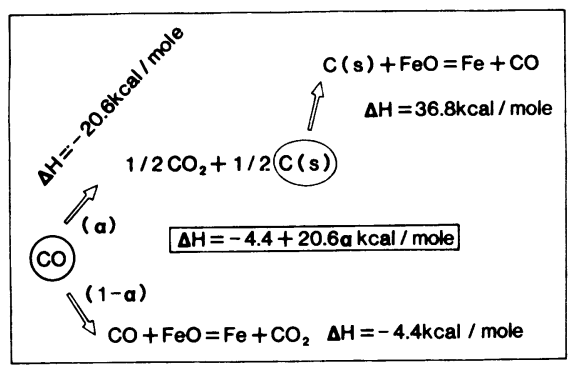

Fig. 2 Mode1 of reaction occurring in tuyere top zone with $\mathrm{CO}$ gas 


\title{
（257）複合吹錬用 $\mathrm{CO}_{2}$ ガス製造プロセスの開発 (製鉄所副生ガスの活用一2)
}

\author{
共同酸素 (株) 鹿島工場 \\ 志野雅美 O豊田隆弘 \\ 住友金属工業（株）鹿島製鉄所 \\ 姉崎正治 植田 稔
}

1. 緒 言

前報では、鹿島におらて世界に先がけて建設した転炉排ガス（ L D G ) を原料とする $\mathrm{CO}_{2}$ 製造設備に つレて、その開発経緯、操業結果を報告した。CO $\mathrm{CO}_{2}$ 製造設備は、昭和 55 年 8 月以来順調に操業を続け ているが、その間、L D G中のサルファ一、ダスト等の微量成分による影響に対する対策、 $L D G$ 組成 の急激な変動に対する対策、製鋼における複合吹錬化の進渉による $\mathrm{CO}_{2}$ 需要増に対する $\mathrm{CO}_{2}$ 増量対策等 を行い、十分な結果が得られたので報告する。

$2 \mathrm{CO}_{2}$ 製造設備操業上の問題点

(1) L D G中のサルファ分は、低温 C O シフト触媒を被毒す る為、2 年間の操業後 C O 転化率が $99 \%$ から $90 \%$ 迄低下 する。又、L D G中のダストは、原料ガス玨縮機のバル ブ、グランド等のトラブルの原因となる。

(2) L D G中の C O 濃度の急激な変動により C O シフト触媒 槽温度が変動し、 $\mathrm{s} / \mathrm{G}$ (原料がスと水蒸気量の比) の触媒 操業における添加水蒸気量管理では操業が困難である。

(3)複合吹練化が進み $\mathrm{CO}_{2}$ 使用量が大巾に増加した為、定格 $500 \frac{\mathrm{Nm}}{\mathrm{H}}$ 以上の $\mathrm{CO}_{2}$ を製造する必要が生じた。

$3 \quad \mathrm{CO}_{2}$ 製造設備の種々の対策

(1) 低温 C O シフト触媒寿命延長の目的で、低温 $\mathrm{CO}$ シフ 卜触媒槽の入口部にサルファガード触媒を充填した。尚 $\mathrm{H}_{2}$ 精製ユニットであるP S A の性能を阻害する $\mathrm{O}_{2}$ 除去の 目的で、脱 $\mathrm{O}_{2}$ 触媒も出口部に充填した。 $(\mathrm{Fig}$. - 1)この 対策により 2 年後の C O転化率を $96 \%$ に維持した (Fig. 2 ）。又、原料ガス任縮機のバルブ, グランド寿命延長 の為、特別な構造のフィルターを設置した。

(2) $\mathrm{C} \mathrm{O}$ 濃度を信号として、添加水蒸気量を変化させる力 スケード制御を採用し安定した操業を行っている。

(3) $\mathrm{CO}_{2}$ 収率向上を目的として、 $\mathrm{CO}_{2}$ 吸収剂である $\mathrm{K}_{2} \mathrm{CO}_{3}$ の濃度を、配管腐食の問題を考虑しながら $29 \mathrm{wt}$ 力から、 $32^{\mathrm{wt}}$ わに高これにより $\mathrm{CO}_{2}$ 収率が $91 \%$ から $98 \%$ に向上した。

4 まとめ

$\mathrm{CO}_{2}$ 製造設備は、種々の対策、改善により安定した操業を 続けており、性能面です計画值を大巾に上回る成績を収めて レる。(Table - 1) 現在、2 号機が昭和 59 年 3 月に稼動 する予定であり、着実に周辺技術を固めている。

文献 1) 中村ら：鉄と鋼 251(1983) S 251

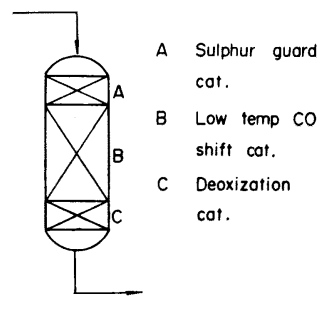

Fig.I Schematic illustration of low temp. co shift converter

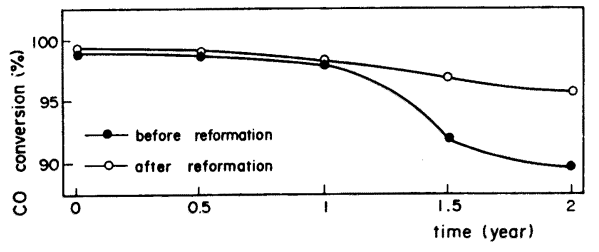

Fig.2 Transition of $\mathrm{CO}$ conversion

Table.I Achieved plant performance

\begin{tabular}{|c|c|c|}
\hline & pian & results \\
\hline LOG Vol. $\left(\mathrm{Nm}^{3} / \mathrm{H}\right)$ & 700 & 700 \\
\hline Steam Vol. $(\mathrm{kg} / \mathrm{H})$ & 1100 & 880 \\
\hline Electric $\quad(\mathrm{Kw})$ & 500 & 450 \\
\hline Product $\mathrm{CO}_{2}\left(\mathrm{Nm}^{3} / \mathrm{H}\right)$ & 500 & 550 \\
\hline Product $\mathrm{H}_{2}\left(\mathrm{Nm}^{3} / \mathrm{H}\right)$ & 300 & 340 \\
\hline Yield $\mathrm{CO}_{2} \quad(\%)$ & 91 & 98 \\
\hline Yield $\mathrm{H}_{2} \quad(\%)$ & 65 & 71 \\
\hline $\begin{array}{r}\mathrm{CO}_{2} \text { composition } \\
\mathrm{CO}_{2}(\%) \\
\mathrm{H}_{2}(\%) \\
\mathrm{N}_{2}(\mathrm{ppm}) \\
\text { dew point }\left({ }^{\circ} \mathrm{C}\right)\end{array}$ & $\begin{array}{r}\geq 98 \\
- \\
\text { Balance } \\
-60 \\
\end{array}$ & $\begin{array}{c}\geq 99.8 \\
0.15 \\
100 \\
-60 \\
\end{array}$ \\
\hline $\begin{array}{r}\mathrm{H}_{2} \text { composition } \\
\qquad \begin{aligned} \mathrm{H}_{2} & (\%) \\
\mathrm{O}_{2} & (\mathrm{ppm}) \\
\mathrm{N}_{2} & (\mathrm{ppm}) \\
\text { dew point } & \left({ }^{\circ} \mathrm{C}\right)\end{aligned}\end{array}$ & $\begin{array}{c}\geq 99.999 \\
- \\
- \\
-\end{array}$ & $\begin{array}{c}\geq 99.999 \\
1 \\
\operatorname{tr} \\
-75\end{array}$ \\
\hline
\end{tabular}


' $84-\mathrm{S} 258$

\section{（258）福山第 2 製龬工場における排ガス回収制御システム}

日本鋼管本社 坪井勇

福山製鉄所 後藤桂三 江種俊夫 ○福田正親

白谷勇介 石川博章

1. 緒 言

転炉排ガス回収量増加は、エネルギーコスト低減の有力な施策のひとつである。当所では、回収量了 ップのために排ガス回収計算制御システムの開発を進め、第 2 製鋼工場 $\mathrm{O} G$ 化の際に転炬プロセス計算 機を更新したのに併せて実用化した。本報告では、この回収制御システムの概要拉よび操業結果につい て述べる。

2. 回収制御システムの概要

回収制御システムは、炬内発生量予測モデルと炬内圧設定

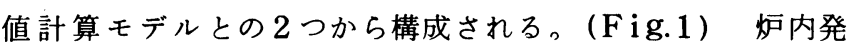
生量予測モデルでは、まず冶金反応論に基づくモデル計算 ( 総合反応モデル）によって予測值を算出した後、予測精度向 上のために、前述の予測値に対して発生量実績値を用いたフ ィードバック演算（実績フィードバックモデル）を実施し、 炉内発生量予測值（修正値）を算出する。炬内圧設定値計算 モデルでは、修正値から炉内圧を計算し、設定値として炉内 圧調節計に出力する。

3. 操業結果

3-1. 炬内発生量の予測精度; 修正值は実績値にからみ合う ように推移しており、炬内発生量予測モデルによる予測精度 の向上は明らかである。( F i g.2)

3 -2. 回収状況: 本システムを実操業に適用した結果、吹鍊 中の $\mathrm{C} \mathrm{O}$ 濃度推移は、次のように改善された。( $\mathrm{F}$ i g . 3) (1) 吹錬初期 : $\mathrm{CO}$ 濃度の立上りが速い。(2)吹錬中期：C O濃 度のレベルが高く、変動が小さい。(3) 吹鍊末期：CO濃度の 高レベル保持。

$3-3$. 回収量への効果; 本システムによる回収実施率は 95 \%以上に達している。これにより、従来方式に比へてて、回収 原単位向上 $3.0 \mathrm{Nm}^{\prime} / \mathrm{T} \cdot \mathrm{S}(\mathrm{P} \cdot \mathrm{R} .=90 \%)$ の効果をもたらし ている。( F i g 。4)
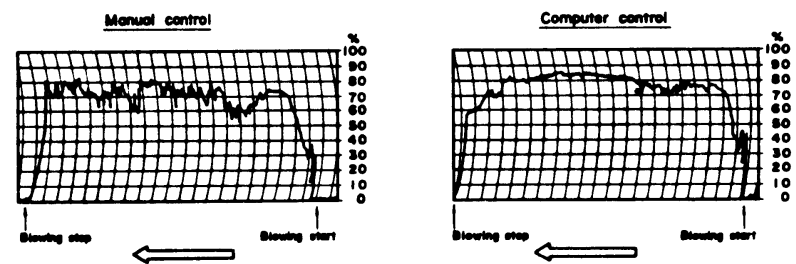

Fig. 3 [CO]\% for blowing time

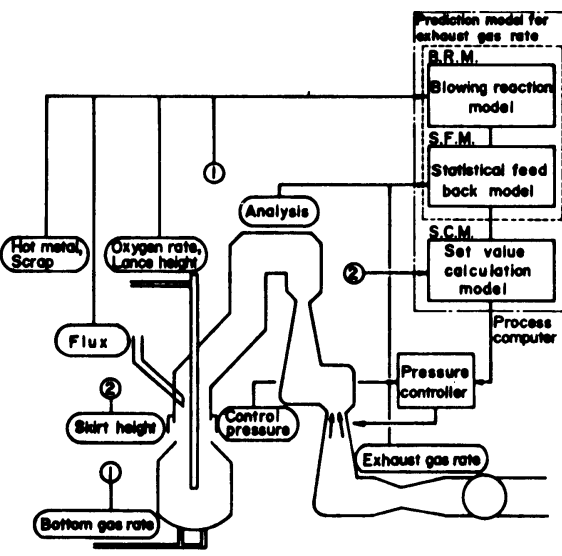

Fig. I Exhoust gas recovery control system

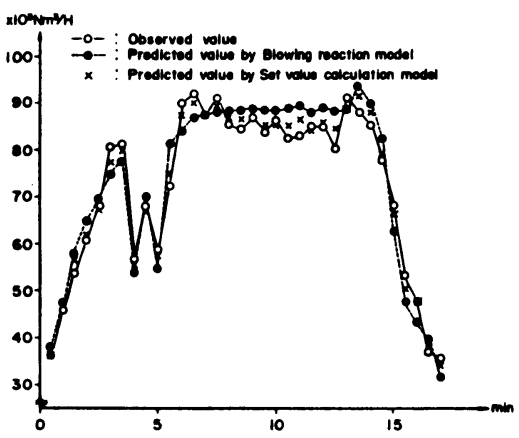

Fig. 2 Exhaust gas rate for blowing time

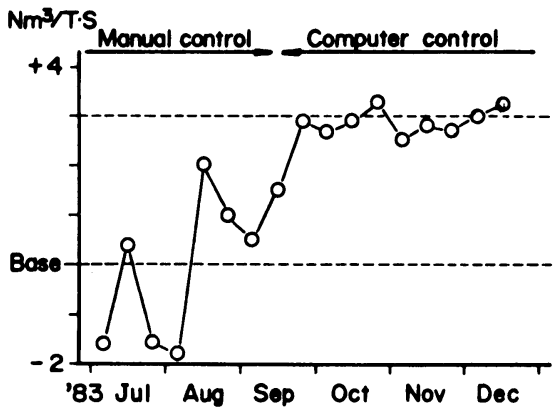

Fig. 4 Recovered gas volume 


\section{(259)}

転炉炉体の変形解析

新日本製鐵(侏) 名古屋製鐵所 三浦 勝

井村正春 森 英朗

○河野一之 戸松正博

\section{1. 緒 言}

転炉々体の寿命を律速する損伤は、鉄皮の熱変形であるが，現在の所その変形機構は明確てはなく， しかも，鉄皮の温度分布を実操炬で広範囲に測定した例はない。当所ては、変形原因を解析する為，第 一製鎆工場 160 トン転炉鉄皮に熱電対及び変位計を取付け, 温度分布と変形量の計測を行い, その結果 をるとに，有限要素法に上る弾塑性解析を実施したので報告する。

\section{2. 計測の方法}

Fig.1亿示す様に, 熱電对 103 点, 変位計を 10 点取付け, 実操炉て, 連続計測を実施した。

\section{3. 計測結果}

鉄皮温度は, 転师操業度と関係があり, 吹錬ピッチが密に なるに従って上界し, 変形量もそれに従って增加する。

Fig.2は, 炉代途中て最高温

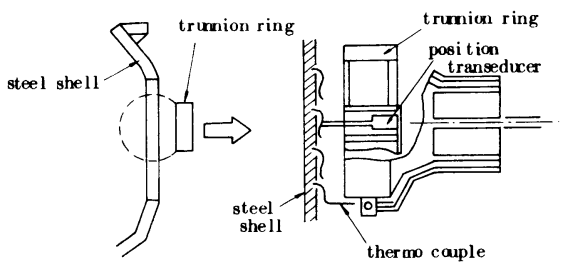

度を記録した時の鉄皮温度分布 と変形量を示している。乙れに ょると。

(1)鉄皮温度分布は, 出鋼側, D.S , W.S 側が高く, 最大 500 ${ }^{\circ} \mathrm{C}$, 装入側恃 $250{ }^{\circ} \mathrm{C}$ 以下である。

(2)鉄皮の変形は, 高温部では 凸方向て最大 $22 \boldsymbol{m} \boldsymbol{m}$, 低温部装 入側で、は度零であ。

\section{4. 有限要素法による理論解析}

転炉鉄皮をFig.3亿示すよ5

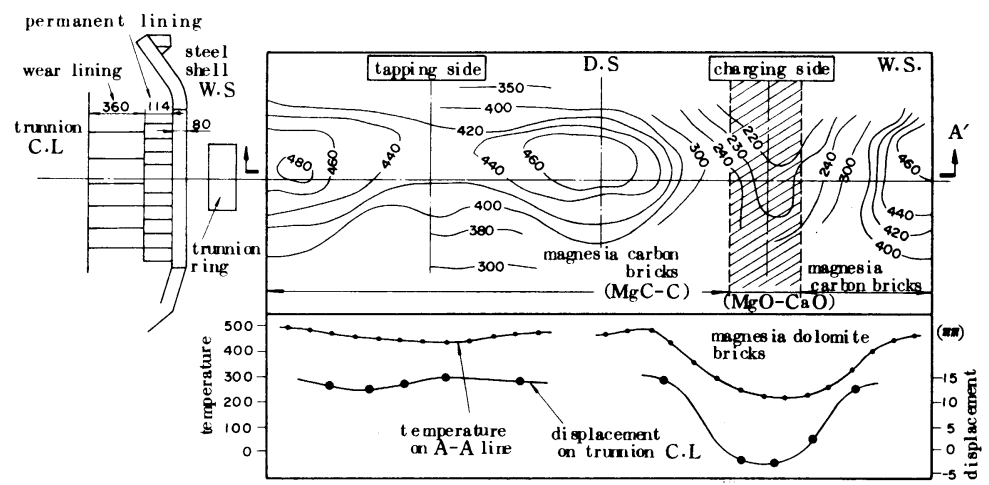

Fig.2 Distribut $i$ on of temperature and $d$ is placement にシェル要素でモデル化し, 実測温度分布を入力し弾 塑性解析る実施した。その結果,

(1)高温時の鉄皮の変形はFig.3に示す様になり, 実 測の変形量と良く一致する。

(2)一回の温度サイクル負荷後の常温時の鉄皮の変形 はFig. 5 亿示す様になり,出鋼側に凸状に永久変形を 生ずるととを示しており, 現実の変形傾向と一致する。
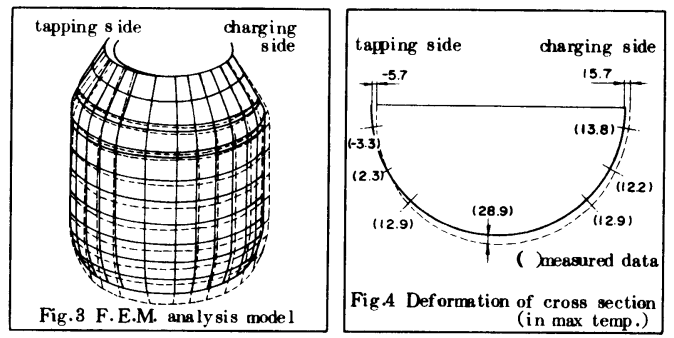

\section{5. 結 言}

計測結果から，鉄皮の温度は予想以上に高く変形量も大をいてとが判定し た。また, 有限要素法による理論解析結果加 , 鉄皮変形の主原因は, 鉄皮 温度上昇に伴ら弾塑性熱変形と考えられる。

今回の計測結果及び理論解析結果は, 今後の鉄皮材質, 炉材構造など転炉 炉体の最適設計に反映させていく考えである。

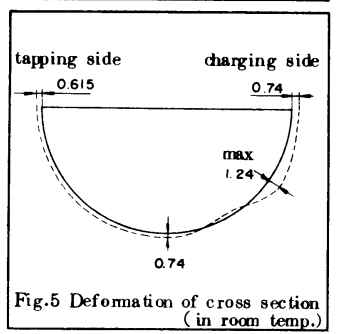


$' 84-\mathrm{S} 260$

(260) 転炉の吹鑇精度向上によるタイレクト出鋇の拡大

新日本製鐵(侏) 名古屋製鐵所 大西保之 野呂克彦 中島酷洋 荻野定志 伊賀一幸○吉田学史 目黒善一 森 正晃

\section{1. 緒 言}

当所第二製鋼工場におらては, 昭和 58 年 3 月に複合吹鍊法（以下ＬD－ＯB）の道入を行ない, 銅谷 の雗拌強化に伴なら転炉吹鍊制御におけるバラッキの減少を図るとともに。[P]の推定精度を向上させる ことにょり，吹止後直ちに出鋼するいわゆるダイレクト出鋼の拡大を図ったのてその概況を報告する。

2. L D - O B の吹鍊特性

L D - O B の冶金特性につんては, 先行 L D - O B 炬 ( 当社 - 八幡・大分・君津) と同様の効果が得 られている。吹鍊末期の脱炭特性・升温特性について, 当工場て使用しているダイナミックモデルの基 礎式(1)・(2)上り，L D 及びL D - O B てのそれぞれの特性值を逆算して，その分布をFig.1飞示す。脱炭

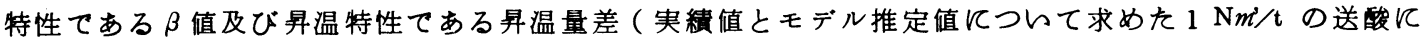
よる昇温量の差）は，L D - O B 化によりそのバラッキが減少している。また，LDーOB化により。 脱[P]能が向上したことから,生石灰の使用量の減少に伴なら 吹鍊の安定性，吹止[P]の推定精度の向上も図ることがてをた。

脱炭式: $-\frac{\mathrm{dC}}{\mathrm{dV}_{\mathrm{O}_{2}}}=a\left(1-\mathrm{e}^{-\frac{\mathrm{C}-\mathrm{C}_{\mathrm{F}}}{\beta}}\right)$

年温式 $: \frac{\mathrm{d} T}{\mathrm{dVo}_{2}}=r-\delta\left(-\frac{\mathrm{dC}}{\mathrm{dVo_{2 }}}\right)$

$$
\begin{aligned}
& \mathrm{C}: \text { 炭素(C)熳度 }(\times 10 \neg \%) \\
& \mathrm{Vo}_{2} \text { : 酸素原単位 }(\mathrm{Nm} / \mathrm{t}-\mathrm{s}) \\
& \alpha \text { : 最高脱炭速度 }\left(\times 10^{-3} \% / \mathrm{Nm} / \mathrm{t}-\mathrm{s}\right) \\
& \mathrm{C}_{\mathrm{F}} \text { : 脱炭限界 }(=2.5)\left(\times 10^{-2} \%\right) \\
& \mathrm{T} \text { : 銅浴温度 }\left({ }^{\circ} \mathrm{C}\right) \quad r \cdot \delta \text { : 定数 }
\end{aligned}
$$

\section{3. タイレクト出鋼の拡大}

当工場て央施しているダイレクト出鋼法をFig.2に示す。サ ブランスにより中間サンプリングを行ない，吹止めのサンプ リングを実施せずに直ちに出鋼を行な5。吹止 $[\mathrm{Mn}]$ ，[P]忙中 間サンプルの分析值から推定し, 合金添加量（最終調整はボ トムバブリングヌは R H ) ，出鋼可否を決定している。

ダイレクト出鋼の実績をFig.3に示す。ダイレクト出鋼の抬 大により測温サンプリング時間を大幅に短縮しまた吹鍊制 御精度の向上により後吹率は大幅に减少し1\%を切るレベル になった。炉寿命すダイレクト出鋼の拡大と石灰石を使用し たスラグューティング等によりLD－ＯB初代炉から2000 回を超え，現在さらに安定した操業を続けている。

\section{4. 結 言}

L D - O B 化に伴な 5 転炬の吹鍊制御精度の向上にょり, ダイレクト出鋼の実施率は $90 \%$ を超えるレベルに達した。そ の結果，製鎆時間の短縮・大幅な後吹率の减少・炉寿命の高 位安定等の効果を得ることがてをた。
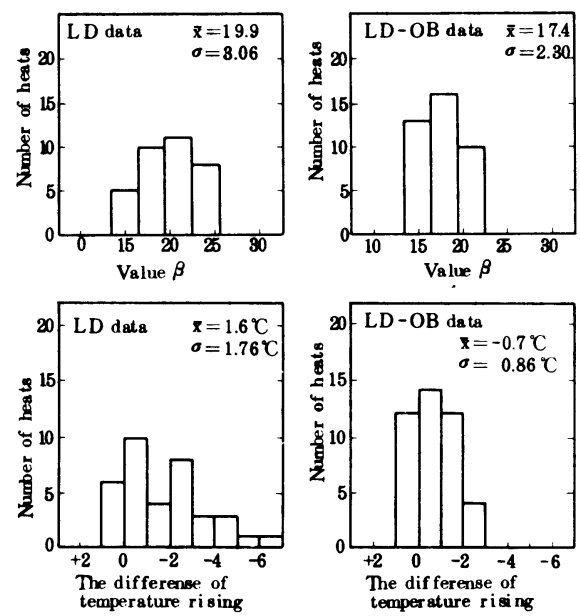

Fig. 1 Change of decarburizing and temperatnre rise charactaristic

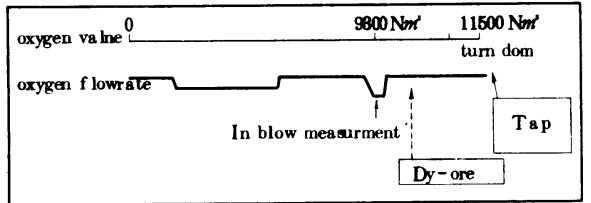

Fig.2 Direct tapping operation

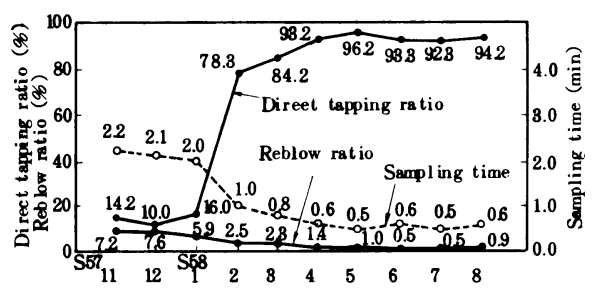

Fig. 3 Direet tapping ratio, Sampling time and rebl ow ratio 


\section{（26I）＼cjkstart複合吹鍊における自動吹錬技術の開発}

\begin{tabular}{|c|c|c|}
\hline 住友金属工業(㑣)鹿島製鉄所 & 多賀雅之 & 戸崎泰之 \\
\hline & 平山憲雄 & 長沢尚人 \\
\hline 制御技術センター & 高輪式志 & 片山勝美 \\
\hline
\end{tabular}

1. 緒 言

鹿島製鉄所第 2 製鋼工場では、S55 年以降 $100 \%$ 複合吹錬 (STB) 操業を実施している。この間、

S T B の利点を更に拡げ、新設の№. $3 \mathrm{CC}^{1)}$ の高能率操業（ダイレクトチャージ）に対応すへくく、自動吹 鍊技術を開発した。本システムを適用した結果、終点適中率の大幅な向上に伴ない、無倒炬出鋼の拡大 が可能となり、製鋼時間の短縮、炉材原単位の低減等、著しい効果が得られたので報告する。

\section{2 自動吹錬システムの構成}

Table 1 に自動吹錬システムの構成 赤す。基本的には 1 ボタン操業を可 能としたが、スロッピング発生時の対 応等、マンーマシンの対話が可能な柔 軟性のあるシステムとした。

3. 自動吹鍊の効果

Table.I Specification of Automatic blowing

\begin{tabular}{|l|l|}
\hline \multicolumn{1}{|c|}{ Static Control } & \multicolumn{1}{c|}{ Dynamic Control } \\
\hline 1 Moterial Charging pattern & 1 Measurement of Sublance \\
\hline 2 Oxygen frow rate pattern & 2 Calculation of supplementary material \\
\hline 3 Lance height pattern & 3 Adjustment of oxygen quantity \\
\hline 4 Sublance measuring timing & 4 Ending of blowing \\
\hline 5 Bottom blowing gas pattern & 5 Ferro-alloy adding control \\
\hline
\end{tabular}

(1) 吹錬適中率の向上

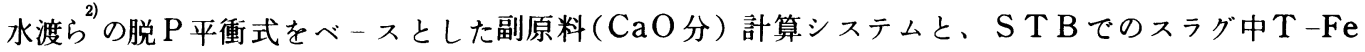
の安定化および自動吹鍊による吹鍊のパターン化により、Fig. 1 に示すように吹止〔P]は非常に安定 し、吹錬適中率は大幅に向上した。

(2) 無倒炉出鋼の拡大

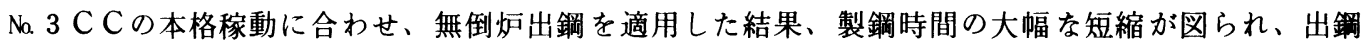
温度の上昇 $(25$ C ) にるかかわらず、むしろ転炉耐火物原単位は減少した。

Fig. 2 に無倒炉出鋼比率、Fig. 3 に転炉耐火物原単位の推移を示す。

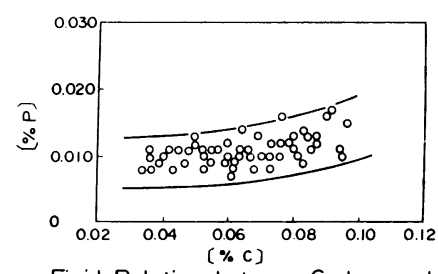

Fig. I Relation between Carbon and Phosporus contents of end point

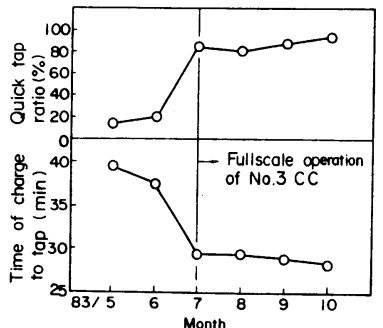

Fig. 2. Transition of Quick tap ratio and Time of charge to tap

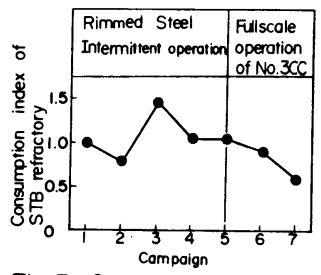

Fig. 3 Consumption index of STB refractory

\section{4. 結 言}

自動吹鍊技術の開発導入により、S T B 操業は非常に安定化し、C C の高能率操業に対応するととも に、品質の安定、耐火物原単位の低減等、多くの効果老得た。
（参考文献）
1）多賀他
本講演大会 (第 107 回) 発表予定
2）水渡他
鉄と鋼 $67(1981)$ 


\section{1. 緒 言}

冷延鋼板の材質特性の向上を目的として，極低炭素溶鋼の経済的な溶製法の確立が望まれている。通 常, 極低炭素溶鋼は, 転炬出鋼後の溶鋼の真空脱炭処理によって製造されているが, 出鋼後の処理時間 の長いてとが問題である。転炉内で極低炭素濃度域まで脱炭する方法について, 試験転炉による実験を 行い, $18 \mathrm{p} \mathrm{pm}$ まで脱炭の可能なととを確めた。

\section{2. 実験方法}

通常の転炉吹錬では，経済的な脱炭限界は 200 〜 300 ppmであり，底吹き転炉においても100 150 ppm が下限とされている。そこで, Fig.1亿示すように， 上底吹き転炉（L D - K G）において，通常の吹錬法 にて約 200 ppmまで脱炭し，その後，炬内の C O 分圧

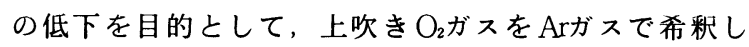
た混合ガスを用いて吹錬した。混合ガス中の $\mathrm{O}_{2}$ ガス漂 度は $0 \sim 67 \%$ あ゙あり, 溶鋼温度は $1630 \sim 1730$ 'Cであった。また，底吹き不活性ガス流量は $0.1 \sim 0.5$ $\mathrm{Nm} / \mathrm{min} \cdot \mathrm{t}$ とした。

\section{3. 実験結果と考察}

実験結果の代表例をFig.2 亿示す。〔C〕は，混合 ガス吹錬開始から $7.5 \mathrm{~min}$ 後に $41 \mathrm{ppm}$ より $12 \mathrm{~min}$ 後に $18 \mathrm{ppm}$ なった。その後, $10 \mathrm{~min}$ 間吹鍊したが 〔C〕は徐々に增加し，吹錬終了時には，40 50 ppm であった。吹鍊中の〔C〕と〔O〕の関係をFig.3 に示す。

(C〕と〔O〕の関係は, $\mathrm{PCO}=0.1 \mathrm{~atm}$ と平衡する 值まで低下可能で， R H 脱ガス装置による真空脱炭処理時の値 とほぼ等しい。また,〔C〕と〔O〕の関係におよぼす $\mathrm{O}_{2}$ と $\mathrm{Ar}$ の混合比の影響は明らかでない。極低炭素領域での脱炭酸䒺効 率を考慮すると，〔C〕と〔O〕の関係はPCO $=0.1 \mathrm{~atm}$ との 平衡值以下まで脱炭可能と推算されるが, 系外からの加炭が無 視できなく, $\mathrm{PCO}=0.1 \mathrm{~atm}$ で見掛け上，脱炭が停止するもの と推察される。

混合ガス吹錬時のスラグ中の酸化鉄(T.Feはd吹鍊の経過と共に 徐々に增加し,Fig. 2 の例では， $7.5 \mathrm{~min} て ゙ 29 \%, 12 \mathrm{~min}$ $34 \%$ あった。
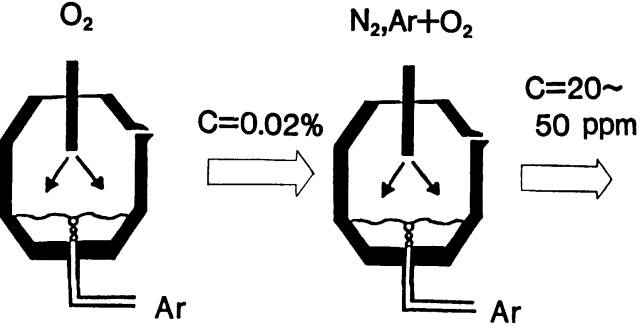

LD-KG ( I )

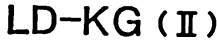

Fig. 1 Process flow of decarburization experiment

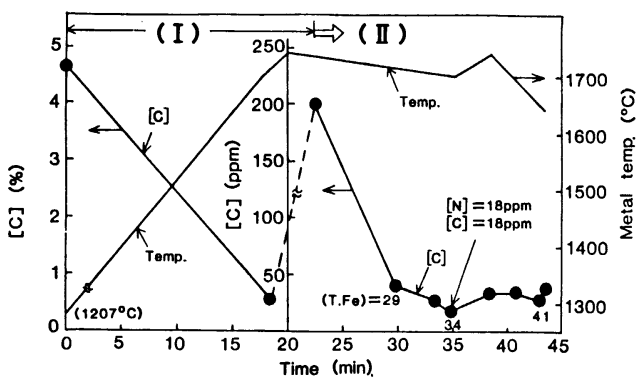

Fig. 2 Changes in Temp. and 〔C

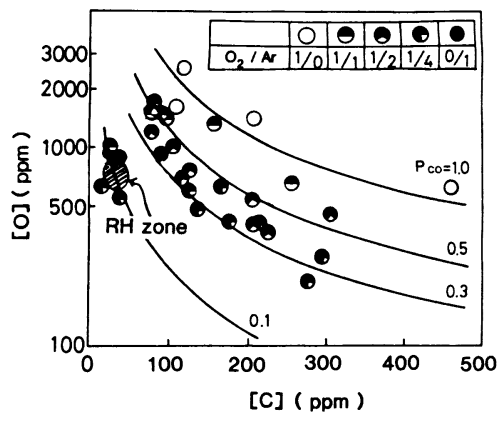

Fig. 3 Relationship between (C) and (O)

4. 結 言：転炉内で極低炭素濃度域まで脱炭する方法について試験転炉を用いて検討し, 混合ガス 上吹き法にて $18 \mathrm{ppm}$ まで脱炭可能なととを確めた。 


川崎製鉄㧣) 水島製鉄所 $\mathrm{O}$ 奥田治志 武 英雄 山田隆康
今井卓雄

1. 緒言 当所では、転西吹鍊時の冷材として鉄鉱石の他に生ドロマイトを使用し精鍊コストの削減を図って きたが、さらに、上底吹き転炉（以下 $\mathrm{K}-\mathrm{B} O \mathrm{P}$ ）の特性を利用したマンガン鉱石の炉内還元を実施し、歩止， 冶金挙動等を調査したので報告する。

2. 使用方法 現在工程的に使用しているマンガン鉱石の化学成分を Table l k示す。マンガン分は、X $\mathrm{x}$ 線回析結果より大部分は $\mathrm{Mn}_{2} \mathrm{O}_{3}$ である。师内へは連投設備を用い、吹鍊中期までに完了するよう投入 Table 1. Composition of Mn ore (\%)
\begin{tabular}{|c|c|c|c|c|c|c|c|}
\hline T.Mn & T.Fe & $\mathrm{SiO}_{2}$ & $\mathrm{CaO}$ & $\mathrm{MgO}$ & $\mathrm{P}$ & $\mathrm{S}$ & $\mathrm{CW}$ \\
\hline 34.26 & 5.24 & 5.23 & 16.89 & 3.02 & 0.019 & 0.068 & 0.91 \\
\hline
\end{tabular} している。

3. 使用結果 (1) マンガン歩止：当所の各転炉においてマンガン鉱 石を炉内添加した場合の吹止( C 〕と $\mathrm{Mn}$ 歩止の関係を Fig. 1 に示す。 マンガン鉣石は従来より、涬化促進等を目的として、L D 炉内に添加 されてきたが、 $\mathrm{M} n$ 歩止が低く精鍊コスト削減効果はわずかであった。 一方、 K - B O P では、底吹き酸素不活性ガス混合処理 ${ }^{1)}$ の適用等に より、吹止時の（ T . F e ) コントロールが容易であり、低炭素濃度域 においても、高い $\mathrm{M}$ 歩止が得られている。

(2)冶金挙動への影譬： K - B O P おおいて、マンガン鉱石を 7 〜 15 $k g / \mathrm{t}$ 使用した場合の吹止( C 〕 と（ T. F e ）の関係を Fig. 2 に示す。 マンガン鉱石の使用により（ T. F e ）の増大傾向がみられる。また、 同一温度, 塩基度およひ $(\mathrm{T} . \mathrm{Fe})$ において比較すると $(\mathrm{Mn}) /(\mathrm{Mn})$, $(\mathrm{P}) /[\mathrm{P})$ は、マンガン鉣石の使用により低下する傾向がみられる。

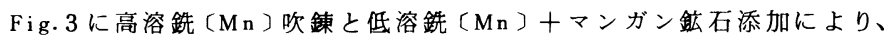
炬内装入 $M n$ 量を等しくした場合のダスト中 T. Mn 発生量の推移を示 す。〔Mn〕の蒸気压は、 $1400{ }^{\circ} \mathrm{C}$ 以上で $(\mathrm{Fe})$ の䄪 1000 倍程度であ り、またフューム中の $\% \mathrm{Mn} / \% \mathrm{Fe}$ は溶鋼中の $(\mathrm{Mn}) /(\mathrm{Fe}]$ に比例する ${ }^{3)}$ ことから、高溶銑( $\mathrm{Mn}$ )法では、吹鍊初期, スラグ量の少ない期間に $\mathrm{Mn}$ のフュームロスが大きく $\mathrm{Mn}$ 歩止上不利と考えられる。

4. 結言 摫汼力の大きいKーBO P においては、マンガン鉱石の使 用により高い $\mathrm{Mn}$ 歩止が得られるほか、Table 2 に示す効果が明らか となった。

\begin{tabular}{|c|c|c|}
\hline item & $(M n)$ HM $=0.3 \%$ & $(M n)$ нм$=0.3 \%+M n$ ore \\
\hline iron ore & base & 7 \\
\hline hot metal & $"$ & $\rightarrow$ \\
\hline burned limestone & $"$ & 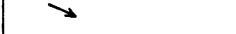 \\
\hline fluor spar & $"$ & $\geq$ \\
\hline oxygen & $"$ & $=$ (equal) \\
\hline (Mn) at blowing end & " & $\Longrightarrow$ \\
\hline temp, at blowing end & ." & $z$ \\
\hline slag volume & " & $\rightarrow$ \\
\hline
\end{tabular}

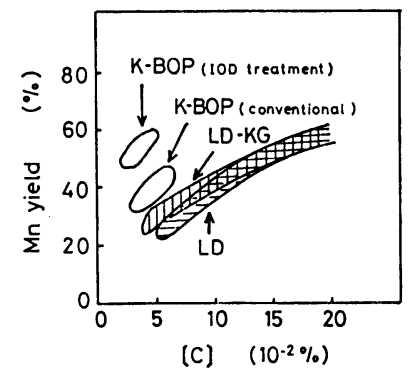

Fig.1. Relation between (C) and $\mathrm{Mn}$ yield at blow end

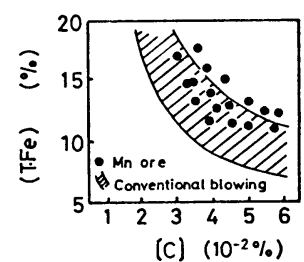

Fig.2. Relation between (C) and $(\mathrm{FFe})$ at blow end

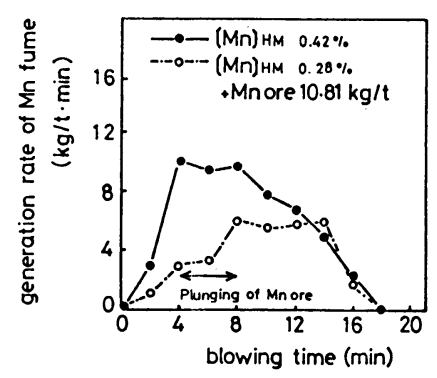

Fig.3. Generation rate of Mn fume in blowing period.

参考文献 1) 奥田ら：鉄と鋼 69(1983)S303

2) M. olette et al : Le Vide No.130 213-225

3) L. von Bogdandy et al : Stahlund Eisen 78 (1958)792-798 
(株)神户铇所・神户整铁所大西稳泰，川崎正荿，高木雨

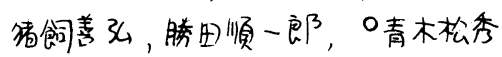

1.緒言：予備观理溶銑の転炉での熱補㑽源として、また。ス クラップレイシオの自由度を掋げるため、炭素系昇熱剂のテス 卜を実施したところ良好を昇瑥効果が得られたので、この結果 を報告する。

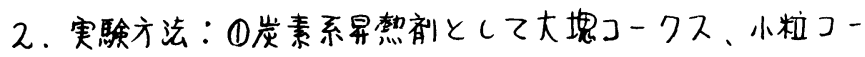

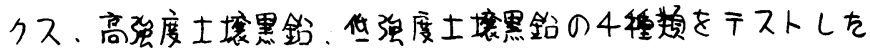
。これらの成分值、粒度をTable 1に示す。また，小粒コ一ク スにフリては、水分の高いものもテストした。(2)転炉への冬 加は、吹羳前に炉上バンカーからあ出し一括投入しえ。

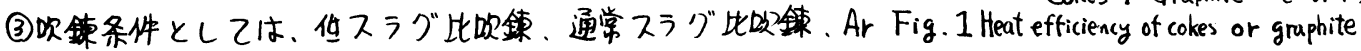

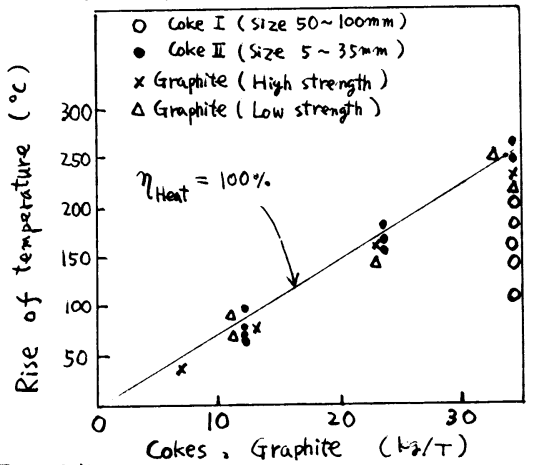
ガス应吹あり、をしとした。

3、实験暂果と考察

(1)开温効果：粒度の小さい場合は、熱勃率がほぼ100\%の异温

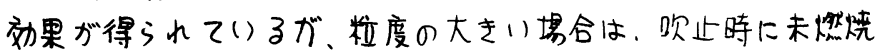
カーボンが存在するちめ温度のバラッキが大きくなり䓡効辛も 憲くなることが判明した。( Fig. 1$)$

(2)硫黄バランス：客銑、スクラップ，开熱剂をどからのインプ

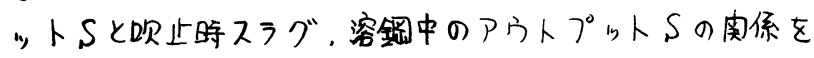

Frg.2に示す。インプットSとアウトプットSは、ほぼ等しく 氛化脱硫は少ないと考察でをた。

(3)空素しヘル：コークス，黑鈆の使用により吹止[N]が上早す ることが判明した。とくに大堌コ一クスの塄合、溶解速度が掘 1)ため吹止时にもコークスの究解による窑素の溶鉋への溶解が あるため吹止[N]が高く存ると考察できた。また，Ar应吹によ

1)黑鉊を添加した場合でも吹止[N]が低く存ることが判明した -(Fig. 3)

(4)水妻レベル：高水分コークスを使用しても吹止[H]レヘルは 低くなることが判明しえ。

(5) OG回収がス: 炭素系异㷫剂の使用による OG回収がスの回

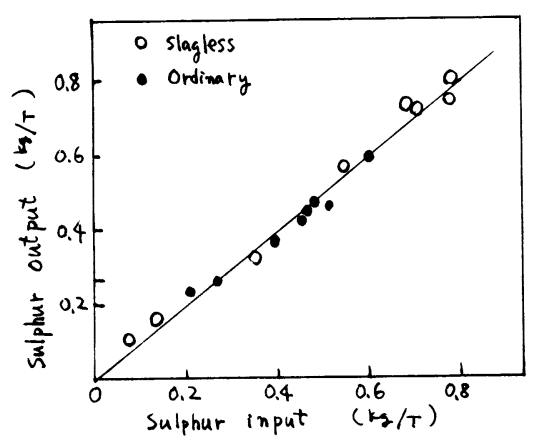

Fig. 2 Sulphur balance

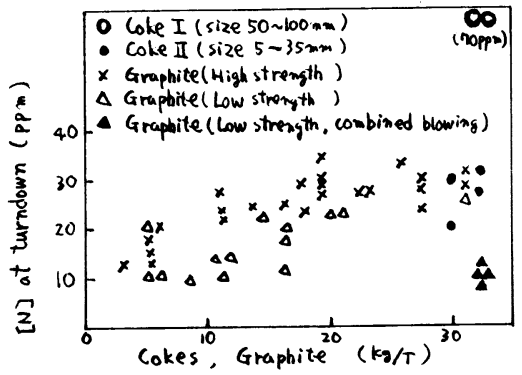

Fig. 3 Nitrogen by coles or yruphite 收效率は䄪 $95 \%$ と良好存成绩が得 小。

4、結言：転炉での宸素系开熱刺の使 用テストをしたとこる、良好左早温効 果の得られることが判明した。

\begin{tabular}{|c|c|c|c|c|c|c|c|}
\hline & \multicolumn{6}{|c|}{ Chemical Composition (\%) } & \multirow{2}{*}{$\operatorname{Size}$} \\
\hline & $\mathrm{C}$ & $\mathrm{S}$ & $\mathrm{VM}$ & $\mathrm{ASH}$ & $\mathrm{H}_{2} \mathrm{O}$ & $\mathrm{N}$ & \\
\hline Coke I & 87 & 0.6 & 1.4 & 11 & 6 & 1 & $50-100 \mathrm{~mm}$ \\
\hline Coke II & 87 & 0.34 & 0.9 & 11 & 6,12 & 1 & $5-35 \mathrm{~mm}$ \\
\hline Graphite $\left(\begin{array}{l}\text { High } \\
\text { Strength }\end{array}\right)$ & 83 & 0.2 & 3.0 & 14 & 1 & 0.1 & $38 \times 38 \times 23 \mathrm{~mm}$ \\
\hline Graphite $\left(\begin{array}{l}\text { Low } \\
\text { Strength }\end{array}\right)$ & 83 & 0.2 & 3.0 & 14 & 1 & 0.1 & $38 \times 38 \times 23 \mathrm{~mm}$ \\
\hline
\end{tabular}




\section{（265）タンデイッシユ内溶鋼加熱装置のピンチ効果現象とそのー考察}

（連続鍀造におけるタンディッシュ内溶鋼温度制御法の開発一４）

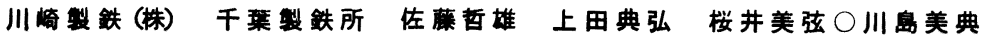 技術研究所木下勝雄}

\section{1. 緒 贯}

千莱 $1 \mathrm{C} \mathrm{C}$ タンディッシユ内溶鋼加熱装置注、鋳込初期および末期のタンデイッシュ内の溶鋼温度降 下防止を目的として開発され、試験運転中である。現在までの実験て、特に錆込の初期において、ピン チンク発生に上る電源トリップ現象を生ずるととがあつた。本報告では、ピンチンク発生から電源トリ ップに至るむでの過程の解析およオ゙ピンチンク抑制についての検討結果を報告する。

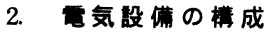

Fig.1亿溶鋼加熱装置の主回路を示す。主な装置構成は、単相のインダク タ、リアクトルとコンデンサからなるロードバランサ,力率改善用コンデン サお上び電源変压器である。ロードバランサは、単相のインダクタが電源へ 与える影遙を考唐して設置されている。

\section{3. 調查検时内容}

溶鋼中に流れる電流が同一方向であるため、導体である溶鋼に向心力が発 生し収粳する。ついには電流は流れなくなり元に戻る。ピンチンクとはての 様な現象が繰り返されるととをいう。ての現象が発生したとさの電源への影

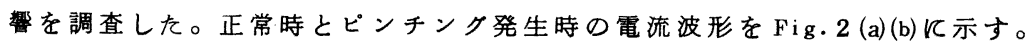

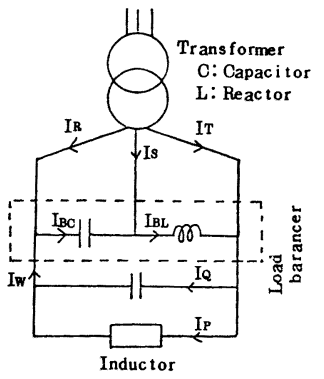

(Fig.1) Main Circuit of Tundish Heater

この測定結果から、ピンチング発生時の電源への影繁を解析して みる。正常時のべクトル図をFig.3に、ピンチンク発生時のべクト ル図をFig.4亿示す。正常時飞は、ロードバランサの効果て $|\mathrm{Is}| \geq|\mathrm{IR}|$

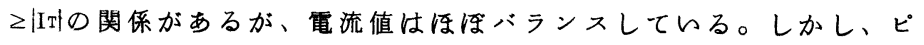
ンチンクが発生すると、2 次抵抗の增加かつ変動のため、|IR|が增加 し、変動する。このため電源トリップとなり、加愁不能に至る。

\section{4. 考}

(1) ピンチンク時には、各相の電流バランスが崩れるので、てれ 飞着目するてとて、検出は可能である。

(2) ピンチング抑制のためには、すみやか 飞投入電力を抑制するととが必要である。 これは電源のサイリスタ化等により可能で ある。

\section{参考文献}

(1) 小原ら , 鉄と鋼 69 (1983) $\mathrm{S} 208$

(2) 吉井万, 鉄と鋼 69(1983) S209

(3) 吉井万, 鉄之鋼

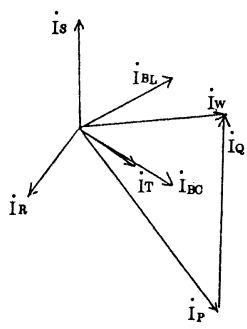

69(1983) S931

(Fig.3) Vector diagrams

in normal state

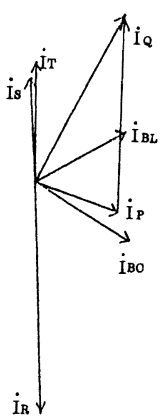

(Fig.4) Vector diagrams during pinching

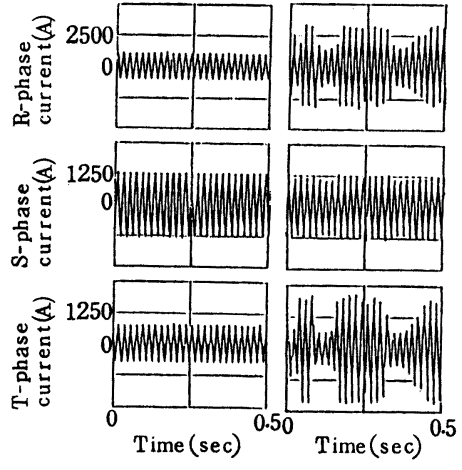

(a) in normal

(b) during

state pinching

(Fig.2) Shape of current wave

$\dot{I}_{R}, \dot{I}_{B}, \dot{I}_{T}:$ Line currents of R-phase, S-phase, and $\mathrm{T}$-phase respectively $\dot{I}_{B L}:$ Reactor current

$\dot{I}_{B C}$ : Balance Capacitor current

İ : Capacitor current

Iि : Inductor current

Iw : Vector sum of $\dot{I}_{P}$ and $\dot{I}_{Q}$ 
' $84-\mathrm{S} 266$

\section{（266） 介在物のスラグ中への移行挙動解析 （連鋳タンディッシュにおける介在物浮上除去方法の開発 第2 報 ）}

住友金属工業(㹯) 鹿島製鉄所 丸,川雄浄 川崎守夫 ○中島敬治

1. 緒 言 溶鋼一スラグ界面に到着した介在物のスラグ相への移行、すなわちスラグによる吸収 につんて検討することは、タンディッシュにおける介在物浮上除去を考える上で重要である。そこで本 報告では介在物のスラグ中への移行挙動に関して、まずGurevitch ${ }^{1)}$ の理論を基に、溶鋼による流体抵 抗および界面エネルギー変化を考慮した補正を施すことにより、改良一介在物挙動モデルを設定して、 スラグ中への介在物移行速度を表わす式を導いた。つづいてこのモデルに基づいて、介在物形状、スラ グ物性值等の影響について検討した。

2. 溶鋼一スラグ界面における介在物挙動の解析 溶鋼内に対流がないと仮定し、角柱状および球状 の介在物が溶鋼からスラグへ移行する場合の速度 $\mathrm{dx} / \mathrm{dt}$ を考察した。すなわち、Fig. 1 に示すような重 力 $\mathrm{R}$ 、浮力 $\mathrm{F}$ 、流体抵抗力 $\mathrm{Q}$ 、界面張力による力 $\mathrm{dE} / \mathrm{dx}$ といj 4 種類の力の釣合いから、 $\mathrm{dx} / \mathrm{dt}$ を介 在物の大きさ、界面張力の差および粘性などの関数として(1)〜(6)式のように求めた。むた、これらの式 による $\mathrm{dx} / \mathrm{dt}$ の計算結果の一例を Fig. 2 に示した。

（角柱状介在物）……底辺 $\mathrm{a}$, 側稜 $\ell$

$$
\begin{aligned}
& \frac{\mathrm{dx}}{\mathrm{dt}}=\frac{\mathrm{na}^{2}\left(\rho_{\mathrm{m}}-\rho_{\mathrm{i}}\right) \mathrm{g}+2(\mathrm{n}+1)\left(\sigma_{\mathrm{mi}}-\sigma_{\mathrm{si}}\right)}{6 \mathrm{~m} \pi \mu_{\mathrm{s}}} \cdot \mathrm{e}^{-\frac{\mathrm{na}\left(\rho_{\mathrm{m}}-\rho_{\mathrm{s}}\right) \cdot g}{6 \mathrm{~m} \pi \mu_{\mathrm{s}}} \cdot \mathrm{t}} \\
& \text { ここで、 } \mathrm{n}=\ell / \mathrm{a}, \mathrm{m}=(3 \mathrm{n} / 4 \pi)^{\frac{1}{3}}
\end{aligned}
$$

（球状介在物）……半径 $\mathrm{r}_{\mathrm{i}}$

$$
\frac{\mathrm{dx}}{\mathrm{dt}}=\frac{2}{9} \cdot \frac{g \mathrm{r}_{\mathrm{i}}{ }^{2}}{\mu_{\mathrm{m}}} \cdot \frac{\left[\rho_{\mathrm{m}} \phi_{\mathrm{F}}\left(\mathrm{x} / \mathrm{r}_{\mathrm{i}}\right)-\rho_{\mathrm{i}}\right]}{\phi_{\mathrm{Q}}\left(\mathrm{x} / \mathrm{r}_{\mathrm{i}}\right)}-\frac{1}{3} \cdot \frac{\sigma_{\mathrm{ms}}}{\mu_{\mathrm{m}}} \cdot \frac{\phi_{\mathrm{E}}\left(\mathrm{x} / \mathrm{r}_{\mathrm{i}}\right)}{\phi_{\mathrm{Q}}\left(\mathrm{x} / \mathrm{r}_{\mathrm{i}}\right)}
$$

ここで、 $\phi_{\mathrm{F}}\left(\mathrm{x} / \mathrm{r}_{\mathrm{i}}\right), \phi_{\mathrm{Q}}\left(\mathrm{x} / \mathrm{r}_{\mathrm{i}}\right), \phi_{\mathrm{E}}\left(\mathrm{x} / \mathrm{r}_{\mathrm{i}}\right)$ はそれぞれ浮力、

流体抵抗力、界面張力による力に対する補正係数である。

$$
\begin{aligned}
& \phi_{\mathrm{F}}\left(\frac{\mathrm{x}}{\mathrm{r}_{\mathrm{i}}}\right]=\frac{1}{4}\left[1-\frac{\rho_{\mathrm{s}}}{\rho_{\mathrm{m}}}\right]\left[\frac{\mathrm{x}}{\mathrm{r}_{\mathrm{i}}}\right]^{3}-\frac{3}{4}\left[1-\frac{\rho_{\mathrm{s}}}{\rho_{\mathrm{m}}}\right]\left[\frac{\mathrm{x}}{\mathrm{r}_{\mathrm{i}}}\right]^{2}+1 \\
& \phi_{\mathrm{Q}}\left(\frac{\mathrm{x}}{\mathrm{r}_{\mathrm{i}}}\right]= \begin{cases}{\left[1-\frac{\mu_{\mathrm{s}}}{\mu_{\mathrm{m}}}\right]\left[\frac{\mathrm{x}}{\mathrm{r}_{\mathrm{i}}}\right]^{2}-2\left(1-\frac{\mu_{\mathrm{s}}}{\mu_{\mathrm{m}}}\right]\left[\frac{\mathrm{x}}{\mathrm{r}_{\mathrm{i}}}\right]+1} & \left(0 \leqq \mathrm{x} \leqq \mathrm{r}_{\mathrm{i}}\right) \\
\frac{\mu_{\mathrm{s}}}{\mu_{\mathrm{m}}} & \left(\mathrm{r}_{\mathrm{i}} \leqq \mathrm{x}\right)\end{cases} \\
& \phi_{\mathrm{E}}\left(\frac{\mathrm{x}}{\mathrm{r}_{\mathrm{i}}}\right)=-\left(1-\frac{\mathrm{x}}{\mathrm{r}_{\mathrm{i}}}\right)+\frac{\sigma_{\mathrm{si}}-\sigma_{\mathrm{im}}}{\sigma_{\mathrm{ms}}}
\end{aligned}
$$

〔記号〕 $\mu_{\mathrm{m}}, \mu_{\mathrm{s}}$ : 溶鋼, スラグの粘度 $\rho_{\mathrm{i}}, \rho_{\mathrm{m}}, \rho_{\mathrm{s}}$ : 介在物, 溶鋼, スラグ の密度, $\sigma_{\mathrm{im}}, \sigma_{\mathrm{ms}}, \sigma_{\mathrm{s} \mathrm{i}}$ : 介在物一溶鋼, 溶鋼一スラグ,スラグー介在物間の界面張力 3. 結言 角柱状小よび球状の介在物に関して、そのス ラグ中への移行速度を表わす式を導いた。これらの式から粒子 径が小さい場合、移行速度は界面張力による力と流体抵抗力に よって支配されることがわかった。また、この界面張力による 力は 3 つの界面張力 $\sigma_{\mathrm{im}}, \sigma_{\mathrm{ms}}, \sigma_{\mathrm{si}}$ の大小、すなわちスラグ組成 介在物組成によって、吸引力に抵抗力にもなり得ることもわ かった。

文

献

: 1) Y.G.Gurevitch : Izv.vUz Cherr. Metall,

$(1968), 8,0,5$

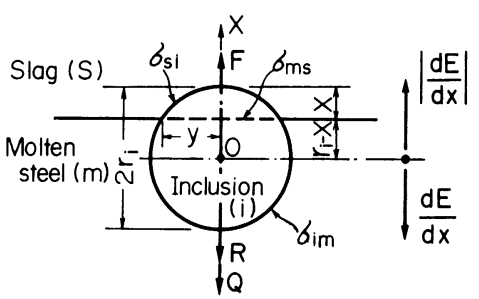

Fig. 1 Force acting on spherical inclusion passing across molten steel-slag interface.

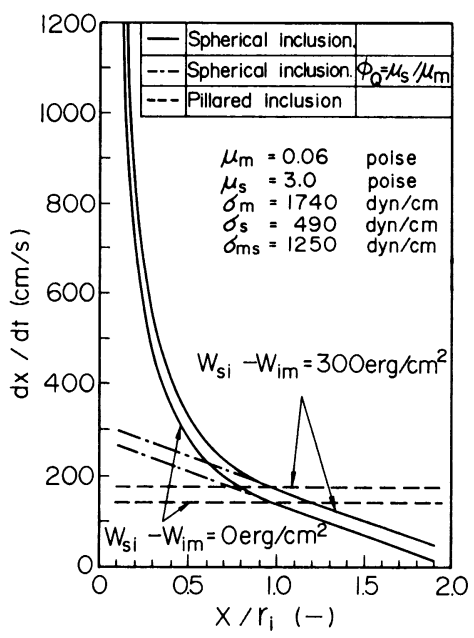

Fig. 2 Velocity of inclusion passing across molten steel-slag interface. 
住友金属工業树小倉製鉄所 木村和成 二木弘美 龟子伸二 西峯 保 神屋幸一。上野明彦

\section{1. 緒言}

連鋳鋳片の表面及び表皮下品質を確保するためには、モールド内の溶鋼湯面レベルの安定化が重要で ある。小倉製鉄所ブルーム連鋳機では、湯面レベルの一層の安定化を目的として、スライディング・, ズル（以下 $\mathrm{S} / \mathrm{N}$ と略す）・ワークシリンダー の直接制御化を実施した。また同時に、タンデ イッシュ耐火物費の低隇を目的として、従来の 3 層式 $\mathrm{S} / \mathrm{N}$ 加 2 風式 $\mathrm{S} / \mathrm{N}$ への転換を図っ た。

\section{2. 改善内容}

(1) $\mathrm{S} / \mathrm{N}$ ワク・シリンダーの直接制御

Fig. 1 亿、直接制御の制御構成図を示す。 従来のサーボ・シリンダーによる位置検出に 代えて、ワーク・シリンダーの位置を直接検 出することにより、間接制御系の油圧ライン を省略した。その結果、油の圧縮等による応 答の遅れが解消され、湯面レベル変動幅は、 従来の土5 mm から士2.5 man改善された。

( Fig. 3 )

(2) 2 層式 $\mathrm{S} / \mathrm{N}$ の採用 ( Fig. 2)

ブルーム C Cへの 2 渞式 $\mathrm{S} / \mathrm{N}$ の適用に際 して、浸清ノズルの折損等操業上のトラブル 発生か懸念されたため、 $\mathrm{S} / \mathrm{N}$ 摺動ストロー クの短縮等の対策を実施した。また、湯面レ ベル検知用の放射線が浸清ノズルと干涉する 点については、線源位置変更等により克服し た。以上により、現場への適用は順調に進み、 タンディッシュ耐火物費の低減に寄与してい る。

\section{3. 品質}

直接制御方式導入により、湯面レベルが安定化した結果、 鋳片表皮下介在物の発生頻度が低減した。

\section{4. 結言}

タンディッシュ溶錄流量制御方法の改善として、

(1) $\mathrm{S} / \mathrm{N}$ ワーク・シリンダーの直接制御

(2) 2 層式 $\mathrm{S} / \mathrm{N}$

の採用を実施した。その結果、湯面レベル変動の一層の改善 及びタンディッシュ耐火物費の低減が図れた。

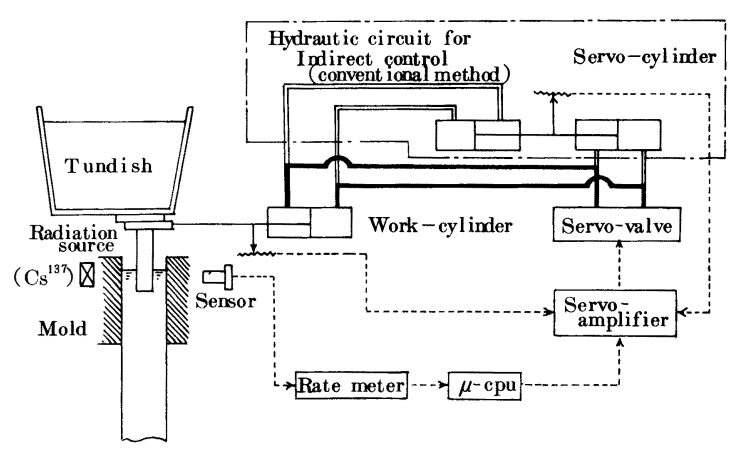

Fig 1 Diagram of Direct control system of Slide-gate work cylinder
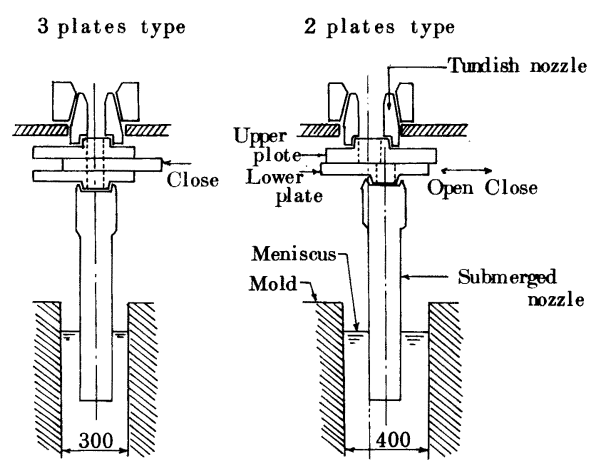

Fig 2 Schematic illustration of 2 piates type slide-gate and 3 plates type slide-gate

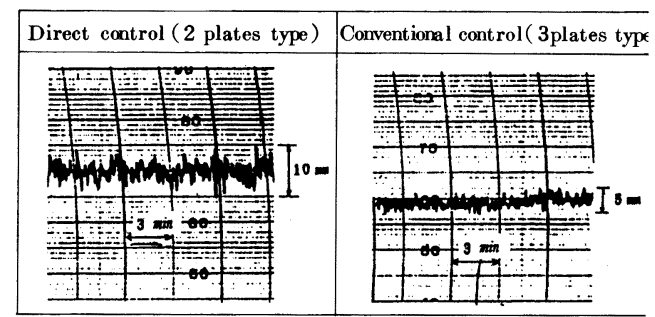

Fig 3 Improvement of level fluctuation in the mold by the direct control system 


\title{
（268）連鋳ビームブランクの無酸化鋳造
}

\author{
日本鋼管福山製鉄所＼cjkstart宮脇芳治半明正之
}

石川 勝 ○白山 章

\section{1. 緒言}

当所 Na 1 連鋳機は、ブルーム，ビームブランク兼用連鋳機であり、形鋼，線棒鋼用素材の製造を行。 ている。一般にビームブランクの鋳造は、その形状的制約から小径のタンディッシュノズルからフィレ ット部 2 ケ所へ溶鋼をオープン注入する方法が実施されている。しかしながら、耐候性鋼，低温衝撃值 保証材等のAl-killed鋼については、ノズル閉塞なく無酸化鋳造を行う必要がある。そこで片側フィレ ット部のみに浸漬ノズルを使用する鋳造法により、安定した操業・品質結果が得られたため、以下に概 要を報告する。

2. ビームブランクの鋳造法

Table-1にビームブランクの鋳造法を示すが、Al -killed 鋼の鋳造は、ストッパーによるモールドレ ベルコントロール及び多孔の浸漬ノズルをフィレッ ト部片側に浸漬させる方法を実施している。Fig-2 にその概要図を示すが、片側からの溶鋼流に対して モールド内の均一性を確保するよう浸漬ノズルを決 定している。吐出孔は反ノズル側一溶鋼を供給する (A)、ノズル側前後面フランジチップヘ溶鋼を供給す る(B)及び下部ストレート孔(C)からな 4 孔タイプで あり、メニスカスでの溶鋼の流動性を適正化するた め、(A) 水平、(B) は下向き 10 度の吐出角度とした。 また吐出孔の方向については、フランジチップュー ナ一部のシェル再溶解を最小とする角度を選定した。 3. 結果

(1) 本鋳造法において、モールド内シェル厚は両 フランジとも均等であり、ビームブランク表面 ・内質の左右の差は認められない。また鋳片形 状, 蛇行もなく操業・品質面において良好な結 果が得られた。

（2）表面疵においても、浸漬ノズル形状の適正化、 2 次冷却水の弱冷化、鋼中 [S] の低减、適正公 ウダーの選定等により、縦割れ、横割れ疵の防 止をはから、良好な成積が得られた。

4. 結言
Table-1 Type of casting condition

\begin{tabular}{|c|c|c|c|}
\hline Steel grade & $\begin{array}{l}\text { Sh roud ing } \\
\text { (Tundish Mold) }\end{array}$ & $\begin{array}{l}\text { Sol } \mathrm{Al} \\
\text { content }(\mathscr{x})\end{array}$ & $\begin{array}{l}\text { Cast ing } \\
\text { speed }(\mathrm{m} / \mathrm{MIN})\end{array}$ \\
\hline $\begin{array}{l}\text { General } \\
\text { structure } \\
(40 \mathrm{Kg} / \mathrm{mf})\end{array}$ & $\begin{array}{l}\text { Open casting } \\
\left(\begin{array}{r}\text { Semi-immersed } \\
\text { nozzle) }\end{array}\right.\end{array}$ & $\leqq 0.005$ & $0.9 \sim 1.1$ \\
\hline $\begin{array}{l}\text { Atomospher ic } \\
\text { corrosion resistant } \\
\text { Marine environment } \\
\text { (Al-killed Steel) }\end{array}$ & $\begin{array}{l}\text { Immersed } \\
\text { nozzle } \\
\text { (Stopper) }\end{array}$ & $\geqq 0.020$ & 0.7 \\
\hline
\end{tabular}

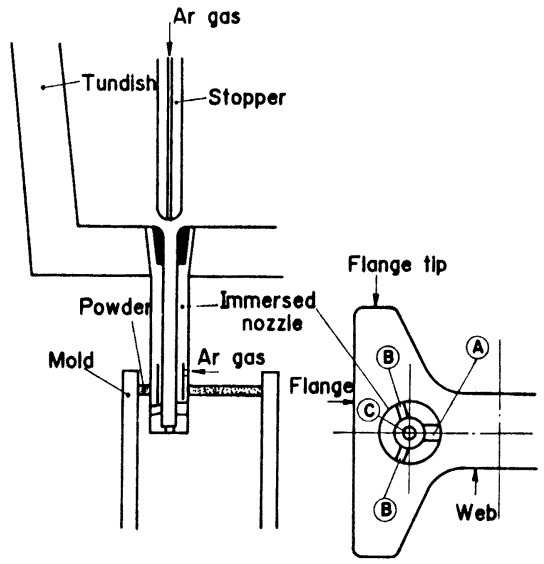

Fig-1 Non-oxydation casting of B B

本鋳造法の適用により、Al-killed 鋼の安定した鋳造が可能となり、現在ビームブランク鋳片のほぼ $100 \%$ 無手入化が達成された。 


\section{（269）鹿島 NO. 3連箐機によるスラフの大型介在物}

住友金属工業（株）鹿島製鉄所

1. 緒 言

鹿島第 3 連鋳機は、介在物低減対策として、垂直曲げ型（垂直部 $3 \mathrm{~m}$ ) 及び、大型タンディッシュ（65 ton）を採用し、S 58 .6ホットラン以 降順調を操業を続けている。以下に今までに得られた垂直曲げ型及び、 大型タンディッシュの大型介在物の低減効果について報告する。

2. 調查方法

1)垂直曲げ型の介在物浮上効果につレては、定常部の鋳片に対して、 スライム法により大型介在物を抽出した。又比較材としては、円弧型連 鋳機の鹿島第 2 連鋳機を用んた。

2)大型タンディッシュの介在物浮上効果については、タンディッシュ 溶鋼重量を変えて、タンディッシュ内にトレーサー $(\mathrm{Fe}-\mathrm{S})$ を添加し、 溶鋼の滞留時間から、介在物浮上率を求め、鋳片の介在物量と比較した。 3. 調查結果

垂直曲げ型と大型タンディッシュの効果につレては、Fig. 1 から、鋳込速度が $1.15 \mathrm{~m} / \mathrm{min}$ の場合で比較すると、総介在物量 で $1 / 3$ 、又 $200 \mu$ 以上の大型介在物では $1 / 10$ に減少し、優位性 が見られた。

1)垂直曲げ型の効果につんては、Fig. 2 の介在物集積位置調 查から、集積位置が中心側に移行し、ピーク高さは低下し、か つ集積幅が狭くなり、垂直曲げ型の特性が明確に出ている。又 $200 \mu$ 以上の大型介在物につんても、同じ傾向が見られた。

2) 大型タンディッシュの効果は、Fig. 3から、垂直曲げ型で タンディッシュ重量を約 $1 / 2$ 倍にすると、計算上では在物浮上 率は約 25３0\%低下する。この計算傎とスライム法による実デ 一夕を比較すると、計算值の方が低目に出ているが傾向として は一致しており、大型タンディッシュの優位性が見られた。

以上の結果より、介在物重要管理鋼種の鋳入及び、大型介在 物の混入し易々、取鍋交換時の境界部の品質向上が期待される。 4. 結 言

鹿島No. 3 連鋳機は、垂直曲げ型及び、大型タンディッシュの 採用により、大型介在物が大幅に減少し良好な結果が得られて いる。

\section{5. 参考文献}
1)橋尾ら：鉄と鋼，67(1981) P. 926
2)丸川ら：鉄と鋼，69(1983) P. 201
3)井上ら：製鉄研究, 第 293 号 (1978)

小林隆衛 浜名孝年 豊田 守 。中山忠士

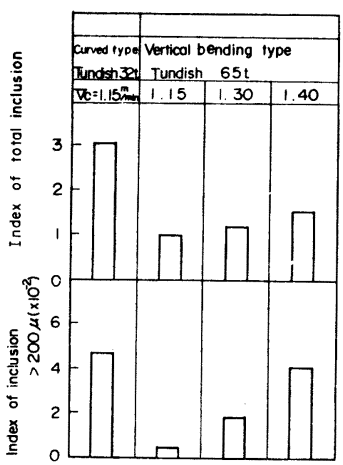

Fig. I Index of large inclusion in slabs cast on two type Continuous casting machine

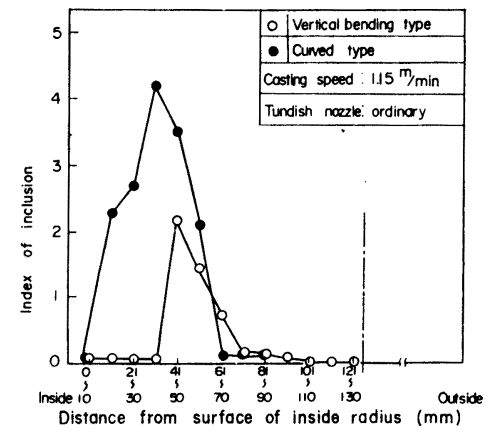

Fig.2 Distribution of large inclusions in slabs cast on two type continuous casting machine

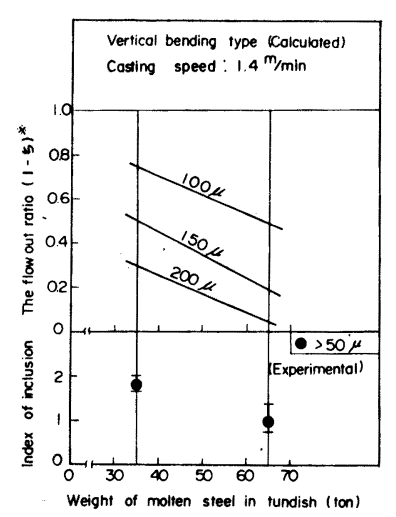

Fig. 3 Effect of large tundish $*(1-5)$. The ratio of inclusions at
inlet and outlet of fundish 
' $84-\mathrm{S} 270$

\section{（270）連絞鋳造における非定常部鋳片の品梊改善}

川崎紫鉄（株）千菜製鉄所 ○柿原節雄馬田一

浜上和久久我正昭

技術研究所吉井裕

\section{1. 緒 砉}

連続鍀造の非定常部、とりわけ取鍋交換などの継目鋳 片の清净度が悪いてとは上く知られている。そこで、75 tonの大容量タンデイッシュを有する千葉 No 3 連鋳機にお いて、介在物の起源調査と、これに基づいた各種の対策 を実施した。その結果につんて報告する。

\section{2. 介在物起源調查}

非定常部鈜片の介在物起源調査のため、トレーサーとし て取鍋スラク, タンデイッシュフラックス，モールドパウダーに、そ れぞれ $\mathrm{BaCO}_{3} ， \mathrm{La}_{2} \mathrm{O}_{3}, \mathrm{CeO}_{2}$ を添加し、鉡造中のタンデ イッシュフラックスやモールドパウダーおよび鉡片内介在物の 組成変化、さらには、介在物量の調査を実施した。銪片 内介在物中に認められたトレーサー成分の分析結果を Table 1 亿示す。乙れより、継目鋂片内に認められる介 在物の起源は、タンデイッシュフラックスの奇与の大きいて とがわかる。次に定常部と継目の、取鍋内とタンデイッシュ 内の溶鋼中の介在物量を Fig.1亿示す。介在物壮定常部 と比較して継目に多い。Fig.2 亿はタンデイッシュ内と鋳 片内の介在物量を示す。鋳片中の介在物の量は、一般の 梁较り用冷延鋼板では製品品質上、問題ないレベルです るが、D I 午クラスの超清净鋼においては、継目錆片で介 在物限界量を超える場合がある。

\section{3. 介在物低減対策}

トレーサー実験から、継目鋳片内の介在物の中にタンデ イッシュフラックスが多量に混入しているととが明らかにな つた。その防止対策として、タンデイッシュ堰形状の改善 や漫漬開孔可能な取鍋ロングノズルを開発じ，DＩ缶クラス の清净鋼の鈽造に採用した。その結果、Fig.3 に示すよ らに、製品における磁粉探賃（M T) 結果は、継目鋳片 においても、定常部と同等の品質レベルが得られた。

4. 結 官

継目鍀片中の介在物の起源を明らかにした。また、超 清净鋼の製造において、継目部す、定常部と同等の品質 が得られる技術を確立した。

\section{(参考文献)}

Table 1 Example of chemical composition of inclusions in slab and tundish flux (wt \%)

\begin{tabular}{|l|c|c|c|c|c|}
\hline \multirow{2}{*}{ Tracer } & \multicolumn{2}{|c|}{ Inclusions in slab } & \multicolumn{2}{c|}{ Tundish flux } \\
\cline { 2 - 6 } & $\mathrm{CeO}_{2}$ & $\mathrm{La}_{2} \mathrm{O}_{3}$ & $\mathrm{BaO}^{2}$ & $\mathrm{La}_{2} \mathrm{O}_{3}$ & $\mathrm{BaO}$ \\
\hline Middle & 0 & 0.87 & 0.07 & 6.73 & 0.20 \\
\hline Ladle change & 0 & 1.70 & 0.16 & 5.90 & 0.34 \\
\hline
\end{tabular}

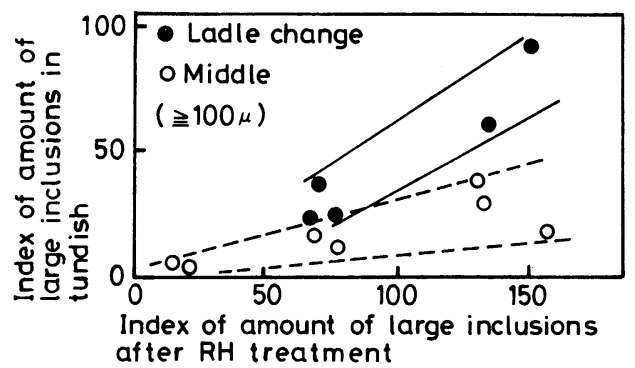

Fig. 1 Relationship between index of amount of large inclusions in tundish and that after $\mathrm{RH}$ treatment

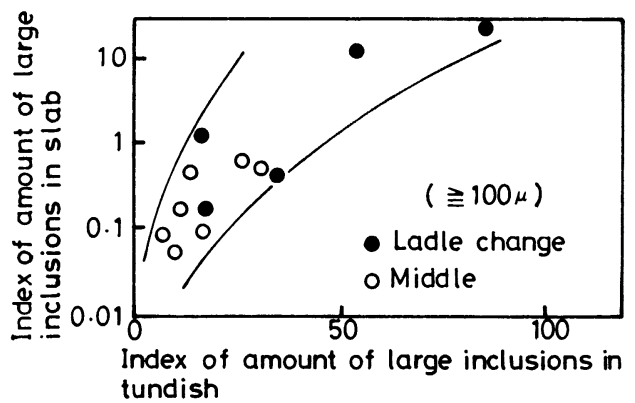

Fig. 2 Relationship between index of amount of large inclusions in slab and that in tundish

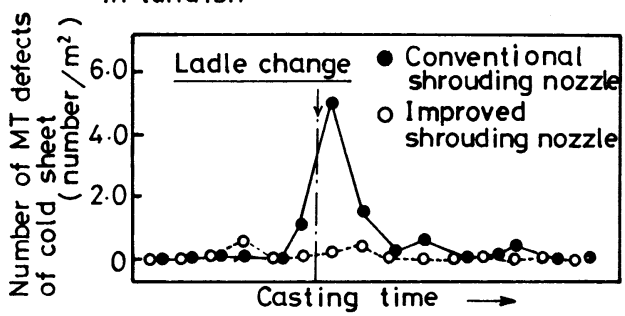

Fig. 3 Transition of MT defects of cold sheet

1) 飯田ら：鉄と鋼 64（1978）S148 2 2) 吉井ら：鉄と鋼 64(1978)S626 3) 上田：公開実用 昭和 $57-127360$ 


\section{（271）硫黄快削銅連鋳ブルームの表面品啠の改善}

$$
\text { ' } 84-\mathrm{S} 271
$$

住友金属
和歌山製鉄所
岸田達 浦 知

○寺口彰俊 田中勇次

\section{I 緒言}

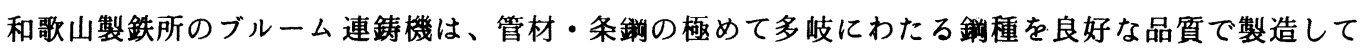
いる 比べ主としてタテワレ原因により鏩片手入比率が高い状況にあった。そてで、主としてパウダーお よび二次冷却水分布を最適化することにょりタテワレの個数および梁さは大巾に減少したので、以下 にその結果を報告する。

\section{II調查方法}

$\mathrm{S} 50 \mathrm{C}$ 硫黄添加銅 $(\mathrm{C}=0.5 \%, \mathrm{~S}=0.06$ $\%$ ) 鋳片表面に発生する微小タテワレについて、 モールドパウダーの物性および二次冷却水の影響 を調査した。さらに発生要因を解明するため、 鋳片より採取したサンプルの引張試験により高温 延性挙動を調查した。

\section{I調查結果}

モールドパウダーの粘度を低下あるいは増加す るととにより、発生するタテワレ症個数は減少し ( F i g 。 1) 。さらに二次冷却水量の低減にと もない疵深さは減少する（F i g 2 ）。

ての結果、鍮片段階での手入は大巾に軽減され た( F i g。3)。

アズキャスト鋳片の高温引張試験によれば、本 鋼種はある冷却速度範囲とある温度範囲で著しく 脆化するととが明らかとなり、以上の結果から本 タテワレはモールド内で発生し、二次冷却帯で拡 大されたものと考えられる。

\section{IV 結言}

硫黄添加 C C ブルーム材において、パウダーと 二次冷却水を適正化するととにより、鋳片表面夕 テワレが減少し銅片手入率が大巾に軽減された。

\section{( 参考文献 )}

1) 辻田ら：鉄と鋼, $69\left(\begin{array}{llll}19 & 9 & 3\end{array}\right), \mathrm{S} 153$

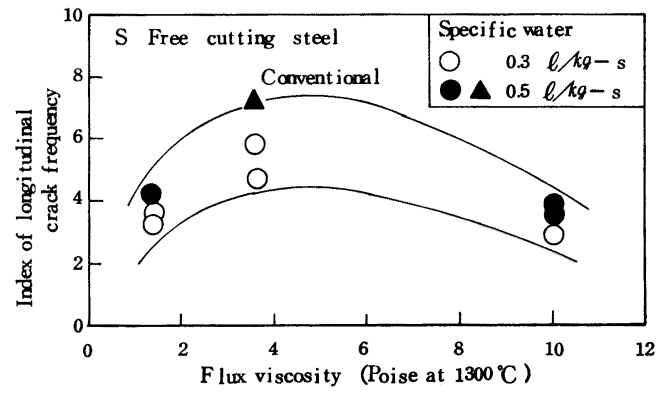

Fig. 1 Relationship between Longitudinal Crack Frequency and Flux Viscosity.

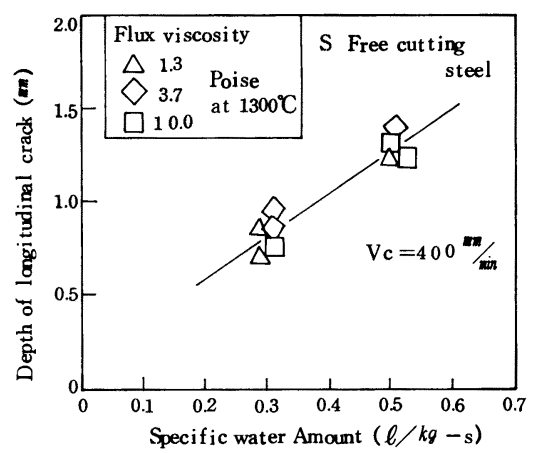

Fig. 2 Relationship between Depth of Long itudinal Crack and Spec if ic Water Amount.

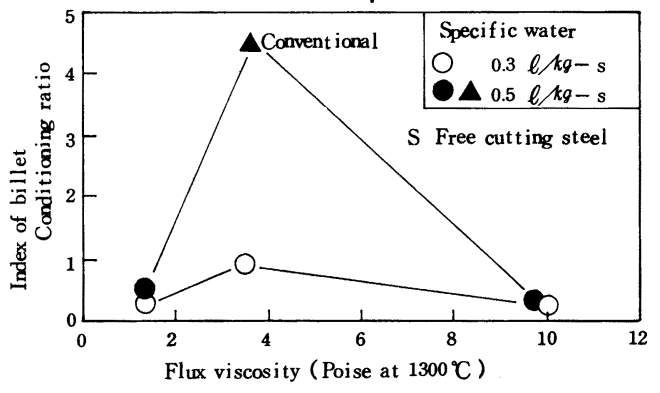

Fig. 3 Effect of Flux Viscositg and Specific Water Amount on Billet Condioning Ratio. 
' $84-\mathrm{S} 272$

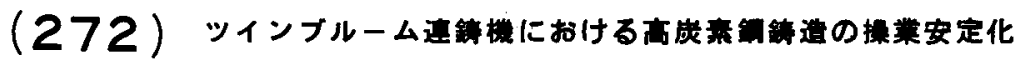

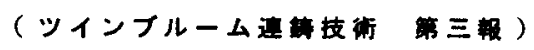

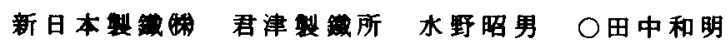

中央研究本部君津技術研究部山口絃一

\section{1. 䋨}

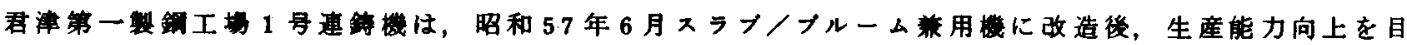

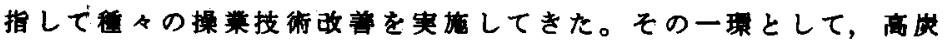
来銅鋳适時に発生する特異な形態のフレークアウトとノスルクロス

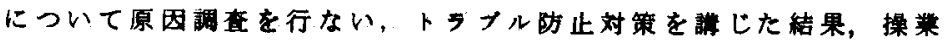
の安定化に成功したので，以下に報告する。（Fig.1）

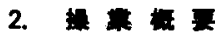

1 号連䥛では, ブルーム生産田 10 万 Ton/月のうち約 $20 \%$ は高

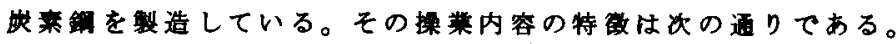

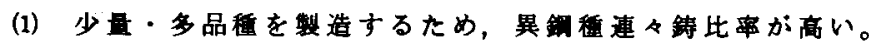

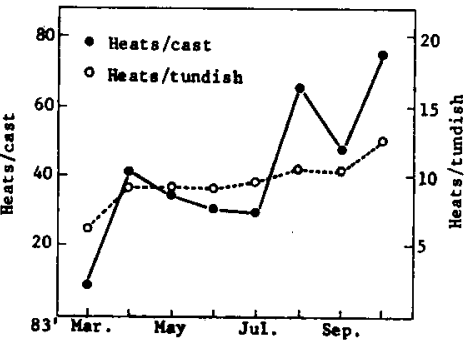

F1g, 1 Trends of the heats/cast and heats/tundish.

同ータンディッシニを使用し，残湦量の減少やモールド内分崔鉄板括入等により，任意の組合せで

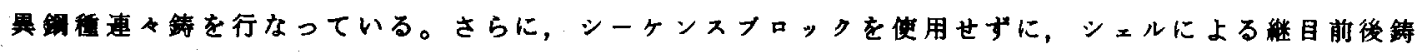

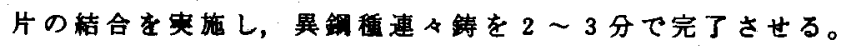

(2) 中心偏析轻娍のため; 低温鋳造( スーパーヒート20 C以内) を実施している。

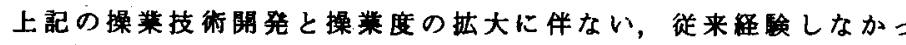
た操菜トタブルが，高蚛来銅鋳造時に発生した。

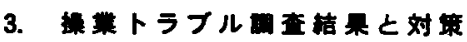

（1）異銅盾連々鋳時の継目漏れブレークフウト

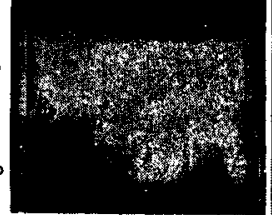

[Low carbon]

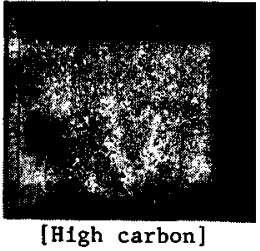

[High carbon] FIg. 2 Sectional photograph of the teeming arrest of low carbon steel and high carbon steel.

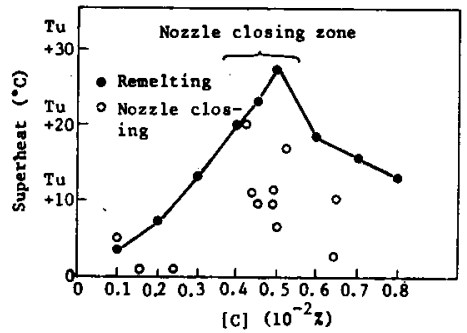

Fig. 3 Relation between carbon content and superheat of nozzle closing and remelting.

(2) 浸流八スル地金詰り

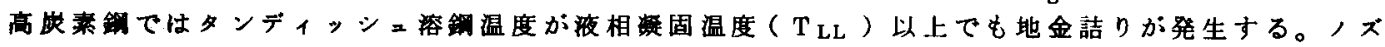
ル内に詰った地金の成分・組織を調查した結果，銥流時の分眍則で成分が負偏析となっており， 低温鋳造時の銅温度では再溶解しにくく，濑固は進行するー方であることがわかった。(Fig.3）

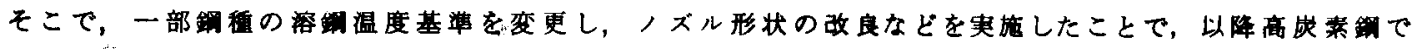
の地金詰りを完全に防止することができた。

4. 濐

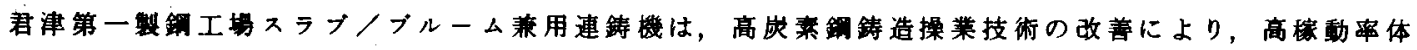

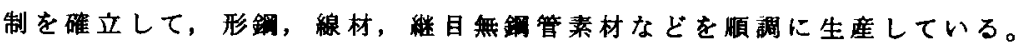




\section{3 )オーステナイト系ステンレス鋼連続鋳造スラブの表面品質の改善と無手入圧延}

新日本製鐵 光技術研究部 竹内英䗪 ○松村省吾 光製鐵所 柳井隆司 小菅俊洋 池原康允

1. 緒 $\overline{\overline{⿳ 亠 二 口}}$

ステンレス鋼連鋳スラブの無手入化は普通鋼連鋳スラブに比へ遅れている。その理由は、ステンレス 鋼冷延鋼板は表面品質の要求が厳しい上に、ステンレス鋼連鋳スラブの加熱炉におけるスケール・オフ 量が普通鋼に比べ非常に少ないため、連鋳スラブに極めて清净な表面品質が望まれるためである。そて でオーステナイト系ステンレス鋼スラブの表面品質改善により無手入圧延化を達成したので報告する。

2. 試験条件および試験方法

Table 1. Continuous Casting Conditions of Slabs

Table 1 に示す条件で鋳造したスラブを無手入のまま 手入スラブと同一条件で熱延一冷延を行ない、最終冷延

鋼板の表面品質を比較調查した。

3. ステンレス鋼連鋳スラブの表面品質の改善

3.1 オッシレーション・マーク (O S M)

1）OSM部の欠陥冷延鋼板で酸洗光沢むらとなる深

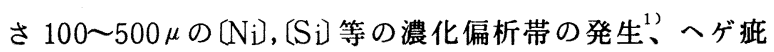
となる微小割れ、線状疵となるパウダー撩込が発生し、 無手入化を阻害する最大要因となっている。

2） O S M 部欠陥の改善 ネガティブストリップ率 $\mathrm{Ne}>\mathrm{O}$ の場合、O S M 深さ、欠陷発生率はネガティブス トリップ時間 $t_{\mathrm{N}}$ を小さくすることで浅く、減少する。 $\mathrm{Ne}<\mathrm{O}, \mathrm{t}_{\mathrm{N}}=\mathrm{O}$ の場合、表面偏析は著しく改善されたが、 パウダー捲込が僅かに増加した。

\section{2 浸炭}

低炭パウダーの適用により表面浸炭を減少させること で、冷延鋼板の表面酸洗光沢むらの発生が防止できた。

3.3 気泡と大型介在物

1）気泡 TDと 1 体化した浸漬ノズルの使用により、 シール用Arガス起因の気泡発生を防止した。

2）大型介在物 TD

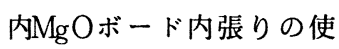
用により、TD付着スカム 起因の介在物を低減した。

\section{4. 無手入圧延結果}

無手入王延より製造し た冷延鋼板は手入压延鋼 板と同等の表面品質である。

1) 竹内ら：鉄之鋼, 68(1982)4, S 163

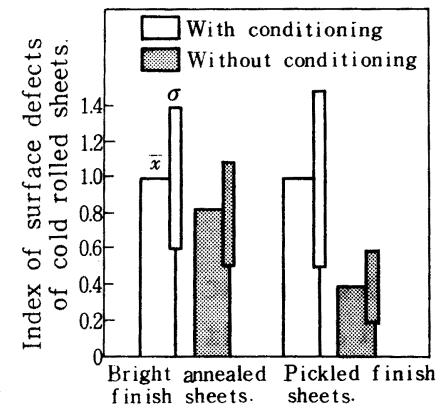

Fig. 2. Comparison of index of surface defects of cold rolled sheets from slabs with and without conditioning.

\begin{tabular}{|c|c|c|c|c|}
\hline \multirow{2}{*}{$\begin{array}{l}\text { Steel } \\
\text { Grade }\end{array}$} & \multirow{2}{*}{$\begin{array}{l}\text { Casting } \\
\text { Speed }\end{array}$} & \multicolumn{3}{|c|}{ Mould Oscillation Conditions } \\
\hline & & Frequency & $\begin{array}{l}\text { Stroke } \\
\text { Length }\end{array}$ & \begin{tabular}{|l|} 
Negative \\
Strip Time
\end{tabular} \\
\hline SuS304 & ${ }^{850} \sim{ }_{1000}^{\text {minim }}$ & $\stackrel{40}{\sim}{ }_{380}^{c p m}$ & $3 \sim 8^{\text {min }}$ & $0 \sim 0.25^{\mathrm{sec}}$ \\
\hline
\end{tabular}

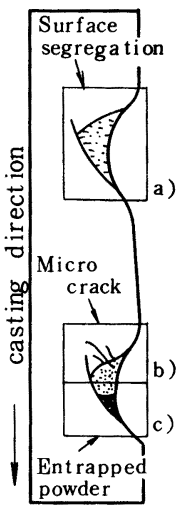

(A) Schema tic

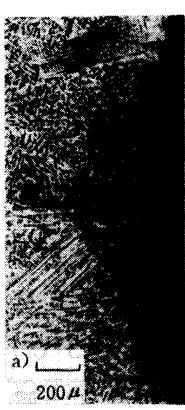

a) Surface Segregation

(B) Micrograph of Defects
Photo. 1. Defects of Oscillation Marks.

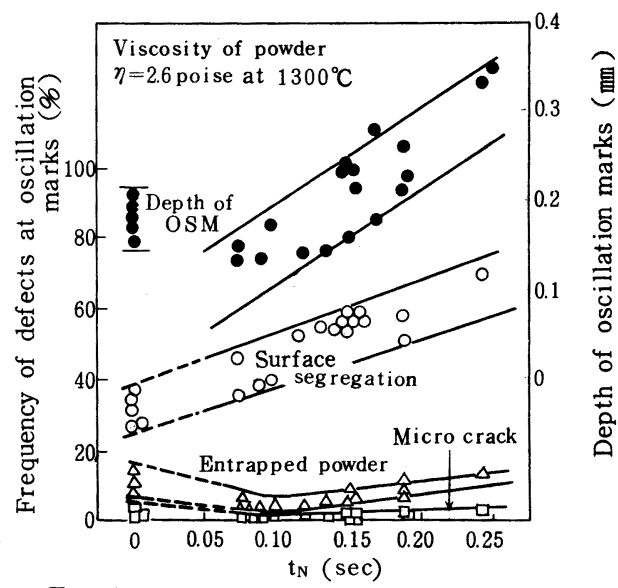

Fig. 1. Relation between negative strip time $\left(t_{N}\right)$ and frequency of defects at oscillation marks. 
' $84-\mathrm{S} 274$

ステンレス鋼連鋳録片のオシレーションマーク

におよ龵す操業条件の影響

日新製鋼（株）周南研究所

○小林芳夫 長谷川守弘

與研究所橋茂昭

1. 緒 言

ステンレス鋼において無手入压延を実施する場合には，スラブ加熱段階でのスケールの生成量が少な く，また，デスケール性が悪いととよりオシレーションマーク（以下，O S M と記す）自体が欠宿とな

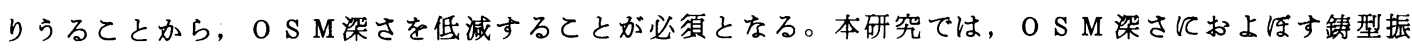
動条件，モールドパウダーの影響について実機での調查を行なうとともに，OS M 生成機構解明のため のシミュレーション実験も実施した。

2. 実験方法

2.1 実機鈇造実験 S U S 430 鋼を $0.7 \mathrm{~m} / \mathrm{m}$ inで録造し た。鋳片サィズは $155 \times 1030 \mathrm{~mm}$ である。鋳型振動条件の影 響については, パウダー一定の条件( 3.8 poise at $1300^{\circ}$ C) ておい て, ストローク； 4 9 $m$, 振動数; $60 \sim 140 \mathrm{cpm}$ で調查 した。他方, パゥダーの影響については, $1.4 \sim 3.8$ poise(at $\left.1300{ }^{\circ} \mathrm{C}\right) の 7$ 種類のパウダーを用い種々の振動条件で鏻造した。

O S M 染さについては, 短辺面のそれを代表値とした。

2.2 シミュレーション実験 鋳片サィズ； $30 \times 100 \mathrm{~mm}$ の小型 実験装置を製作し，ＯS M生成の様子を直接観察した。実験では， 溶融ハンダ $\left(\mathrm{m} \cdot \mathrm{p} 183^{\circ} \mathrm{C}\right)$ を溶鋼に, をた, 溶融安息香酸 $(\mathrm{m} \cdot \mathrm{p}$ $\left.121^{\circ} \mathrm{C}\right)$ を溶融パウダーに見たてた。

3. 実験結果および考察

シシュレーション実験からは,Fig.1亿示すようなOS M生成の 様子が観察された。この結果は, 江見らが提案したオーバーフロ一 メカニズムと一致するものであり, 初期凝固シェル形状が O S M 梁 さて影響するてとを意味する。よって，O S M 梁さておよほす鋳型 振動条件, また, パウダ一の影響は、いずれてれら要因の疑固シ エル形状に対する影響を介して説明されるべをると考えられる。

まず，鋳型振動条件の影響については，一般的には $\mathrm{t}_{\mathrm{N}}$ で整理さ れる場合が多いが，Fig.2亿示すようにストロークによって区分さ れ適正なパラメーターとは言的難く，Fig. 3 亿示すでとく，1 サィ クルの時間 $\mathrm{t}_{\mathrm{s}}(=1 / \mathrm{f})$ での凝固の進行に伴なうシェルの曲げ,およ び $\mathrm{t}_{\mathrm{N}}$ でのパウダーの流入に伴なうシェルの曲げを考㦄したパラメ 一ター; $\left(\mathrm{t}_{\mathrm{s}}+\mathrm{t}_{\mathrm{N}}\right)$ との間に良好な相関が得られる。

一方, パウダーの影響については, ある一定の振動条件下におい て, 低粘性, あるいは, 溶融速度の速いパウダーほどO S M は哚く なるが、ての結果もまた，パウダーの流入に伴なうシェルの曲げを 考慮するととによって説明できる。

1）江見他鉄と鋼 63(1977)S151 2) たとえば荒木他 鉄と鋼 59(1973)A17

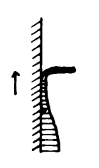

a) At upward movement

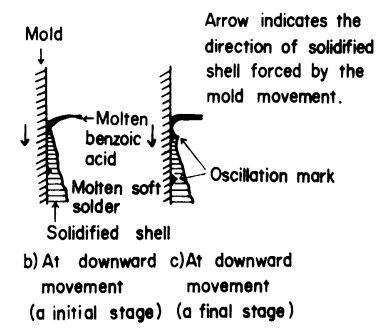

Fig. 1. Schematic representation of oscillation mark formation.

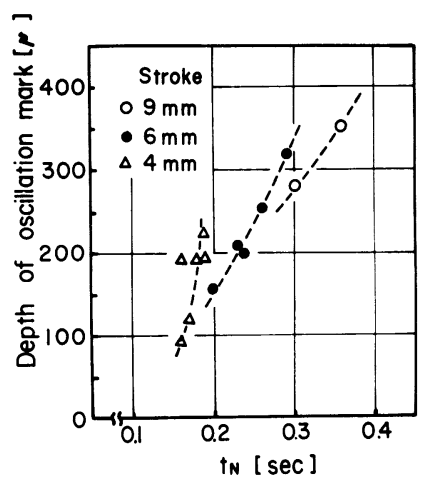

Fig. 2. Relation between depth of oscillation mark and $t_{N}$.

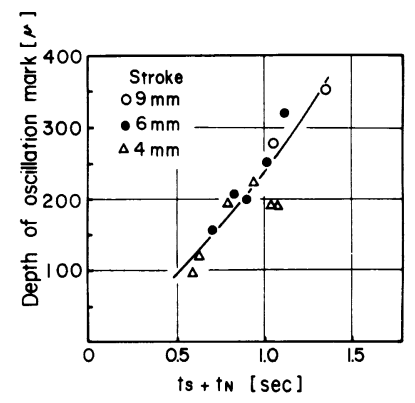

Fig. 3. Relation between depth of oscillation mark and $\left(t_{S}+t_{N}\right)$. 


\section{（275）連鋳鋳型内電磁㿾拌技術の開発}

新日鐵大分 調 和郎 ○味志敏弘 仲 億

\section{1. 緒 言}

当社広畑製鐵所にて開発されたDKM（モールド電磁攪拌 装置）を大分製鐵所での高生産性連鋳機に適用し、モールド 長寿命化及び摫拌特性について調査した。

\section{2. 設備概要}

D K M 装置はF i g 1 に示す様にメニスカス下約 200 m に中 心を持つ 2 ポールコアを冷却箱内に設置したもので、コアは 純水により冷却されており、コアボックス下の冷却箱でモー ルド冷却水の供給を行なう。その他の主要設備諸元について は Table 1 に示す。

\section{3. モールド長寿命化}

高推力を得るためには良電導体である銅板厚みを極力薄く する必要があり、大分ではまず溥肉モールドを指向したが、 寿命, 変形の点で問題があり、複合冷却板モールドを採用し た。(Fig 2)乙れら2つのモールドの変形挙動については、 F E M 熱応力解析と良い一致を示し、また長寿命化について は、はぼ目標を達成した。

\section{4. 流勤解析}

モールド内に於ける電磁攪拌の効果を定量的に把握するこ とを目的として、計算機による流体シミュレーションを実施 した。使用したプログラムは D.B.Spalding らによって、 開発された2-EFIX モデルを用いた。

$$
\begin{aligned}
& \rho\left(\mathrm{u} \frac{\partial \mathrm{u}}{\partial \mathbf{x}}+\mathrm{v} \frac{\partial \mathrm{u}}{\partial \mathbf{y}}\right)=\frac{\partial}{\partial \mathbf{x}}\left(\mu_{\text {eff }} \frac{\partial \mathbf{u}}{\partial \mathbf{x}}\right)+\frac{\partial}{\partial \mathbf{y}}\left(\mu_{\text {eff }} \frac{\partial \mathrm{u}}{\partial \mathbf{y}}\right)-\frac{1}{\mu}\{(\nabla \times \mathbf{B}) \times \mathbf{B}\}+\mathrm{Su} \\
& \rho\left(\mathrm{u} \frac{\partial \mathrm{v}}{\partial \mathrm{x}}+\mathrm{v} \frac{\partial \mathrm{v}}{\partial \mathrm{y}}\right)=\frac{\partial}{\partial \mathrm{x}}\left(\mu_{\text {eff }} \frac{\partial \mathrm{v}}{\partial \mathrm{x}}\right)+\frac{\partial}{\partial \mathrm{y}}\left(\mu_{\mathrm{eff}} \frac{\partial \mathrm{v}}{\partial \mathrm{y}}\right)-\frac{1}{\mu}\{(\nabla \times \mathrm{B}) \times \mathbf{B}\}+\mathrm{Sv}
\end{aligned}
$$

上式に、流体の䑪送方程式と相似な、通到エネルギー（k）と

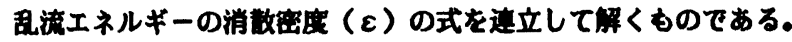
[計算前提]

1）電磁摫拌力はオフラインでの推力計測結果を用いた。

2）計算は鋳造方向に垂直及び平行の 2 断面での流動計算 を行ない評価した。

結果をFig $3 \sim 4$ 亿示す。

\section{5. 結 言}

1)新爆着モールドによる推力増加及び長寿命化により本装 置の長期安定性の見通しが立った。
片岡冬里事 “業”部新岡正樹

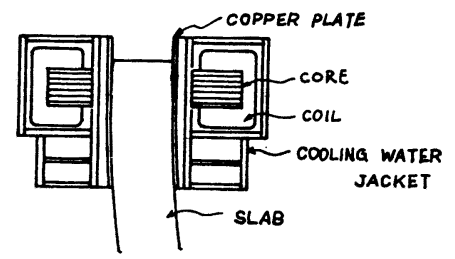

Fig 1. Schematic view of electromagnetic stirrer in the mold (DKM)

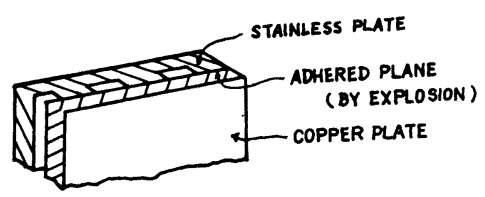

Fig 2. Schematic view of composit mold

Table 1. Specification for DKM

\begin{tabular}{|l|l|}
\hline & Specification \\
\hline mold size & $280 \mathrm{~mm} \times 1800 \mathrm{~mm}$ \\
\hline speed & $1.25 \mathrm{~m} / \mathrm{min}$ \\
\hline Na of poles & $2 \mathrm{poles}$ \\
\hline Ampere & $200 \mathrm{~A}$ \\
\hline
\end{tabular}

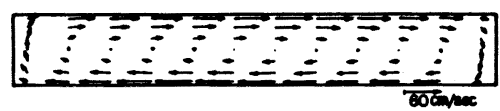

Fig 3. Calculated flow velocity distribution with stirring ( Cross section)

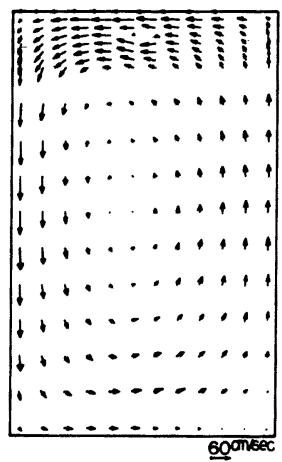

Fig 4. Calculated flow velocity distribution with stirring ( Longtudinal section)

2)流体モデルによる、流速場の把握によりモールド内流動特性をあきらかにした。 
（276）電磁揰拌による疑固遅れと酸化物系介在物の洗浄効果に関するホットモテル実験

川崎製鉄侏技術研究所

1. 緒 言

電磁擋拌は連鋳プロセスに広く利用されているが、凝固現象 や酸化物系介在物の洗浄効果などの基礎的側面については不明 の点が多い。本研究は50kg 溶鋼を用いたホットモデル実験によ りこれらの現象を定量的に把握することを目的に行なったすの である。

2. 実験方法 (Fig.1)

$\mathrm{C} 0.12$, Si $\mathrm{tr}$ Mn $0.40, \mathrm{P} 0.05, \mathrm{~S} 0.005, \mathrm{~A} \ell 0.10 \%$ の溶鋼を水平旋回磁場のもとでステンレス鋳型に鋳造し、所定 時間後に凝固シェル下端をバーナ一開孔し、凝固シェル厚を測 定した。また、鋳塊表層の柱状晶凝固部の大型介在物量を画象 解析装置により測定し、下注ぎ 2 本立て鋳造で得た非摚拌材と 電磁擋拌材間で介在物量を比較して電磁擋拌の効果を評価した。 なお、水平旋回磁場はMax 300 ガウス, 旋回流速はV T R 記 録の解析により求めた。

3. 実験結果とその検討

3.1 凝固速度：溶鋼排出材の凝固シェル厚之凝固時間の 関係を加速凝固を考慮した次式で解析し

$\mathrm{d}(1-2 \mathrm{~d} / 3 \mathrm{R})^{1 / 2}=\mathrm{K} * \sqrt{\mathrm{t}}, \mathrm{d}:$ : シェル厚, $\mathrm{R}:$ 鋳塊半径 $\mathrm{K}^{*}$ : 凝固定数, $\mathrm{t}$ : 凝固時間

凝固定数を求めた。一方、シェル厚測定位置の磁束密度の測定 値を用いて凝固定数との関係を求めFig. 2 を得た。なお、磁束 密度 175,90 ガウスにおける溶鋼の水平旋回流速は 230,150 $\mathrm{cm} / \mathrm{sec}$ であるが踀固の進行にとあなう減衰が大きい。鋳塊の表 層20 muには柱状晶, その内部には多数の微細な等軸晶が観察さ れているので、Fig. 2 の結果は旋回流れによる柱状晶の剪断に よるむのと推定される。なお、凝固中の測温データの解析より 莮断点の固相率は 0.5 程度と推定される。

3.2 介在物洗浄効果: 鋳塊表層部の介在物面積率亡 $\mathrm{Al}_{2} \mathrm{O}_{3}$ ク ラスターの発生率をFig. 3，Table.1 に示す。との結果から、 柱状晶凝固域での摚拌による介在物洗浄効果は明らかである。 なお、Table.1 中の溶鋼流速は柱状晶偏向角から推定した值で ある。これらの結果より、介在物洗浄効果は凝固界面の平滑化 による所す無視できないと考えられ、簡単な考察を加える。
鈴木健一郎

○宮川昌治

村田賢治

中西恭二

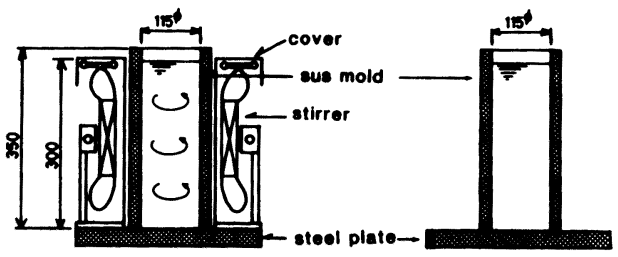

Fig.1 Schematic diagram of experimental apparatus for $25 \mathrm{~kg}$ ingots.

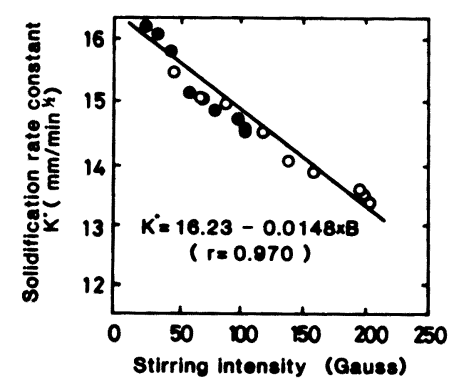

$$
\text { Fig.2 Relation between solldification rate }
$$

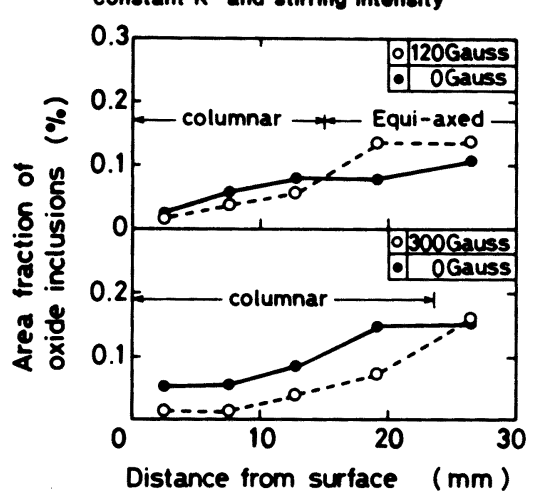

Fig.3 Effect of EMS on oxide inclusions in solidified shell

Table 1 Effect of EM8 on amount of alumina clusters

\begin{tabular}{|c|c|c|c|}
\hline \multirow{2}{*}{ 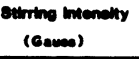 } & \multicolumn{2}{|c|}{ Flow veloolly $(\mathrm{com} / \mathrm{ecc})$} & \multirow{2}{*}{$\begin{array}{l}\text { Nentere of } \mathrm{N}_{2} \mathrm{O}_{3} \\
\text { chentere in } \mathrm{cm}^{2}\end{array}$} \\
\hline & 2 min trom eurtece & Sinn trom enrtecos & \\
\hline 120 & 21.0 & 10.0 & $--\frac{7}{16}$ \\
\hline $\begin{array}{r}200 \\
0\end{array}$ & 32.0 & 14.8 & 15 \\
\hline 300 & & 18.8 & 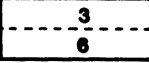 \\
\hline
\end{tabular}




\section{（277） 大断面ブルーム薑鋳颣固末期摚拌に関する基碤検討}

' $84-$ S 277

\section{（濑固末期摚拌の大断面ブルーム連鋳機への適用ーI）}

$\begin{array}{rrrr}\text { 日本鋼管侏技術研究所 } & \text { ○水上秀昭 北川 } & \text { 融 工博川上公成 } \\ \text { 京浜製鉄所 } & \text { 小森重喜 桝井 明 山上 諪 }\end{array}$

1. 緒言著者らは前報1)において凝固末期における最適電磁摚拌方法について央験室的検討を 行なった。今回，本技術を大断面扇島 4 号ブルームC.C.に適用する際に行なったスケールアップに関 する検討結果を報告する。

2. 基䂝英験結果 前報1)で得られた最適擋拌方法に関する知見をまとめると以下のとおりである。

1）最適摚拌時期は鋳片の中心で固相が晶出し始める時期である。 2) 必要な擋拌強度は流速換算 で $10 \sim 20 \mathrm{~cm} / \mathrm{sec}$ の範囲である。 3）最適摚拌パターンは交番擋拌である。

3. 検 封伝熱計算結果より鋳造速度 $0.55 \mathrm{~m} / \mathrm{min}$ の時, メニスカス下 $19 \mathrm{~m}$ の位置で鋳片中心 で固相が晶出し始めることが推定された（Fig.1）。計算結果と実際の固相率分布の対応は次報 ${ }^{2)}$ で報告 する。大断面ブルームC.C.への適用に際し, 擋拌コイルのパワーの決定は重要な問題となる。必要 パワーの検討は以下のように行なった。

溶融金属の流速（周速）は摚拌条件と溶融金属の物性により(1)式で与えられる3

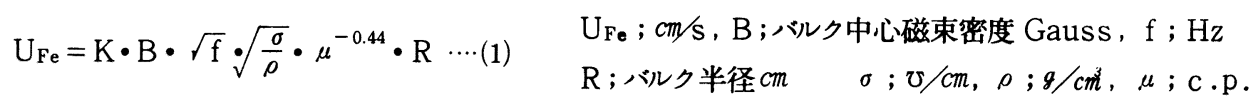

基礎実験結果より $\mathrm{U}_{\mathrm{Fe}}<20 \mathrm{~cm} / \mathrm{sec}$ で凝固末期擋拌の効果が認められたので(1)式に $\mathrm{U}_{\mathrm{Fe}}=20$ を代入して大 断面 B L で必要な鋳片中心での磁束密度(B)を計算する。この際, 固相率(f s)が 0.3 以下の領域が擋拌に よって流動可能とし，また未凝固溶鋼の粘性( $($ )はこの領域の平均固相率より渋谷ら4のデータをもとに 推定した。得られた磁束密度を周波数に対して示したのか Fig.2-(a)である。空間中心での磁束密度 (Bo)は, 種々の大きさのステンレス容器内で磁束密度を測定して求めた減衰率 ( B B Bo) と周波数, 鋳片 サイズの間の関係より計算できる。また，周波数と $\mathrm{B} / \mathrm{B}$ ○の関係を用いてBoが一定の下で各周波数で摚 拌力指数 $(\mathrm{B} \sqrt{\mathrm{f}})$ を計算しFig.2-(b)に示した。図よりおよそ6〜10 Hzが最適と推定された。以上のような 検討結果に基づいて設計・製作したコイルにより実機擋拌試験を行ない，ホワイトバンド部の負偏析度 から溶鋼流速を推定 ${ }^{3)}$ した結果をFig.3に示す。 $20 \mathrm{~cm} / \mathrm{sec}$

程度の擋拌流速が得られておりス ケールアップの妥当性が確認でき

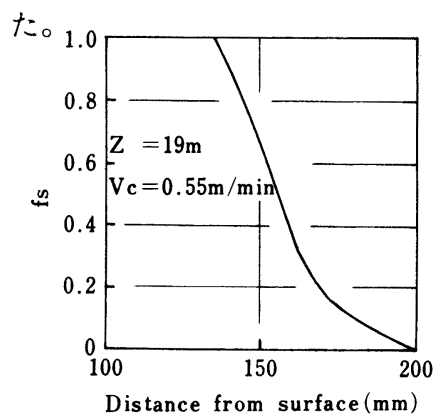

Fig. 1 Distribution of solid fraction at crater end.

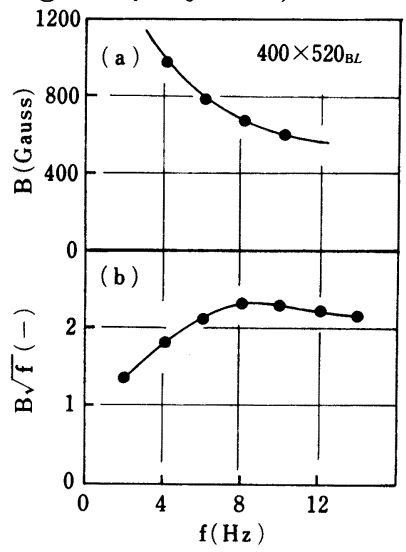

Fig. 2 Relation among $f, B$ and $B \sqrt{f}$
<文献>

1) 水上ら; 鉄と鋼 68 (1982)S 255

2) 北川ら; 本講演大会発表予定

3) 水上ら; 鉄と鋼 68(1982)S 254

4) 橴谷ら; 鉄と銅 66(1980)P1150

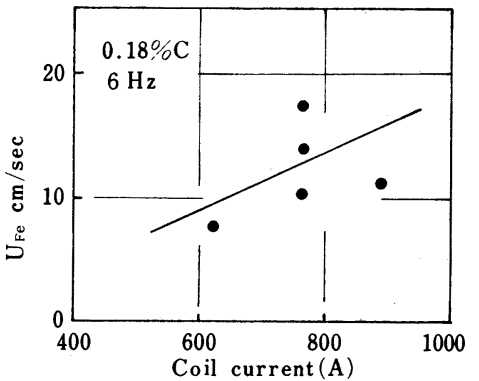

Fig. 3 Relation between coil current and $\mathrm{U}_{\mathrm{Fe}}$. 
（278） 大断面ブルーム連鋳における粶固前面の娭出

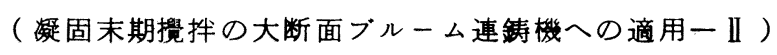

日本鋼管技術研究所 北川 融 小松政美 工博 川上公成 京浜製鉄所山上諒 中島広久 O石坂 祥

\section{1. 緒 言}

連鉡鋳片の軸心欠陥を防止するためには等軸晶の増殖と最終凝固部における等軸晶の充填が重要であ り、電磁擋抖を最終㠜固域にかけるととによってV偏析をる防止しつつ軸心への等軸晶の充城が可能で

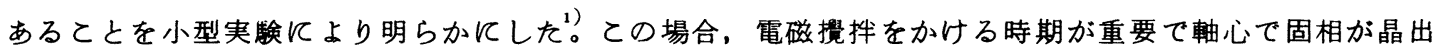
し始める時期が最適であるととが判明している。このたび加速凝固域の広い大断面ブルーム軸心部の疑

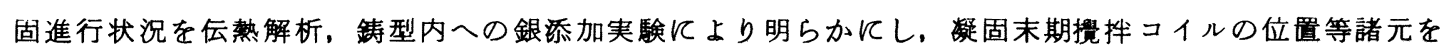
決定する一助としたので報告する。

\section{2. 実験方法}

垂直型ブルーム連鋳機 $(400 \times 520 \mathrm{~mm})$ の定常鍀造中に加熱ないしは溶解した銀 $0.5 〜 20 \mathrm{~kg}$ 鋳型から添 加した。また鋳片の表面温度を二色温度計にて測定し、伝熱計算の確認データとした。鋳造後ブルーム 内の銀の存在位㯰からクレータエンド近傍の等固相率線を决定した。主な鋳造条件は鋳造速度：0.5 m/min,

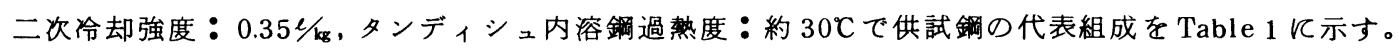

なお, 予め行った小型実験から銀添加により検出される固一 Table.1 Composition of heats. (wt 液界面は固相率， fs=0.09であるととが確認されている。

\section{3. 実験結果及び考察}

\begin{tabular}{|c|c|c|c|c|c|}
\hline $\mathrm{C}$ & $\mathrm{Si}$ & $\mathrm{Mn}$ & $\mathrm{P}$ & $\mathrm{S}$ & sol A $\boldsymbol{l}$ \\
\hline 0.45 & 0.25 & 1.00 & 0.020 & 0.015 & 0.020 \\
\hline
\end{tabular}

添加した銀は添加条件、添加量によらず添加時のメニスカスから約 $10 \mathrm{~m}$ 上り約 $17 \mathrm{~m}$ の範囲に粒状に分散 していた。粒径は 2〜10 mo であり同一横断面上の銀粒分布は添加時の固一液界面上にならばずある範 囲に分散していた。ての分布幅はクレータエンドに近づくにつれて広くなりかつ粒数も增加する傾向に あった。粒の落下速度およびストランドの収縮の影繁を補正し、凝固時間 $\mathrm{t}$ の平方根に対し, 粒/地 鉄界面のブルーム広面からの距離をブロットしてFig.1亿示す。また同図には伝熱解析によって求めた 等固相率線をあわせて示した。銀粒が鉡片表面からの距離に対して㕕がって分布する理由は銀粒が落下 途上において一たん固一液界面に到達後そのらちのいくつかの粒は界面上を比較的低速て落下したため と考えられる。ての点が溶鋼に添加した際大塊として举動する鉛文との差であり，銀添加の場合最も録片 表面に近い粒が真の等固相率面を示するのと考え られる。

小規模予備実験で銀のとどまる固相率が $\mathrm{fs}=0.09$ であったのでFig.1亿示した伝熱解析の結果とは 上記の現象を考虑するとよく一致するといえる。

この結果と連鋳本体の設備条件を考㦄し疑固末 期撸汼用コイルの設置位㯰をメニスカスから 19.4 $m$ と決定した。㩧拌に上り固相率, fs $<0.3$ の領 域が流動すると考えた場合筧找される溶鋼プール 形状は $60 \times 180 \mathrm{~mm}$ と考えられる。

(1)水上ら：鉄と鋼 68 (1982)S 225

(2) T. Kitagawa et al. : Canadian Metallurgical Quarterly 15 (1976) P129

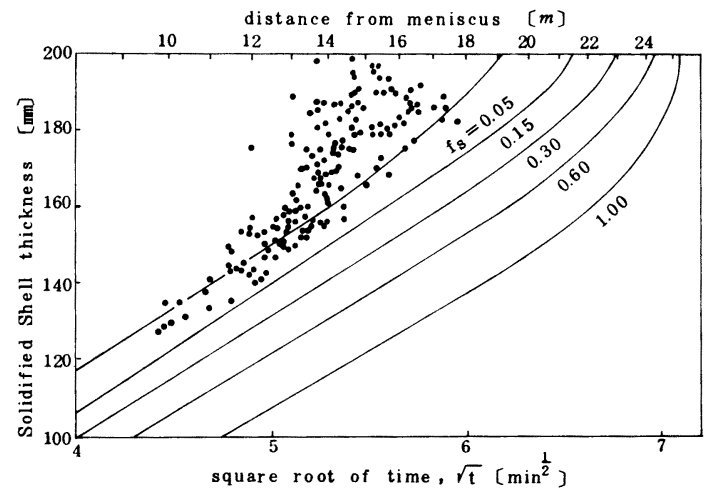

Fig. 1 Comparison of estimated shell thicknees with the location of silver particles in blooms. 


\section{（279）大断面ブルーム連鋳々片品質に及ぼす沀固末期摚拌の影響}

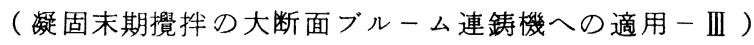

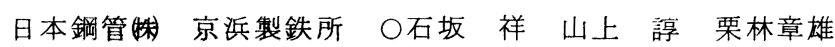
田口喜代美

技術研究所菅原功夫 角南英八郎

\section{1. 緒 言}

大断面ブルーム連鋳機へのモールド電磁熼䢁 (M-EMS)の適

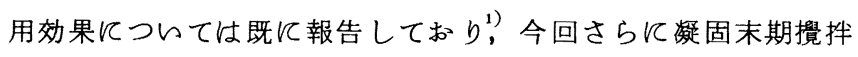
(F-EMS) を導入し，ブルーム鋳片品質に及住す影響について 検討したので報告する。

\section{2. 実験方法}

前報 $^{2) 3)}$ の結果より, 扇島 4 号ブルーム C.C. $(400 \times 520 \mathrm{~mm})$

へ適用する F-EMS 装置の仕様および設置位置は Table 1 ，

Fig 1 亿示す様に決定した。本装置を用い，C=0.15 0.50\%の

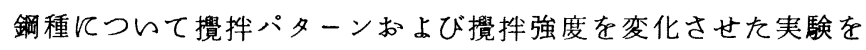
行レ、鋳片内部組織への影響を調査した。

\section{3. 実験結果}

1）Photo 1 Kは，M-EMSが一定の条件で F-EMS（交番穓 䢁）条件を変えた場合の鋳片マクロ組織を示し，Table 2 K はその代表成分を示した。F-EMSの付加にょり，鋳片内部 組織は大巾に改善されるが, F-EMSが過度の場合には攪挥 凝固域にホワイトバンドの生成が観察される。

2）内部組織を定量的に評価するため,Fig 2 K F-EMSの強 度とセンターポロシティ指数の関倸を示す。F-EMS 強度の 增加に従い，センターポロシティは大巾に低減している。ま た内部組織の改善にともない, 鋳片の中央偏析の低減が認め られた。

4. 結 言

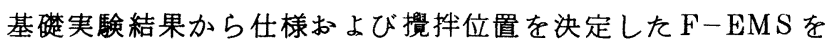
扇島 4 号ブルームC.C.亿適用し、 M-EMS との最適な組合せに よって鉡片品質を大巾に改善した。

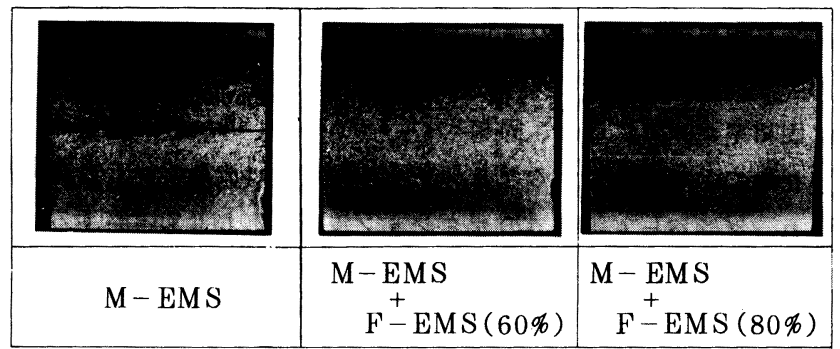

Photo 1 Macro stracture of bloom $(\mathrm{C}=0.23 \%)$
Table 1. Specifications of F-EMS

\begin{tabular}{|l|c|}
\hline coil type & rotary, 2 poles, 3 phases \\
\hline core size & $750 \mathrm{~mm} \phi, 750 \mathrm{~mm}$ \\
\hline capacity & $600 \mathrm{KVA}$ \\
\hline frequency & $1 \sim 12 \mathrm{~Hz}$ \\
\hline
\end{tabular}

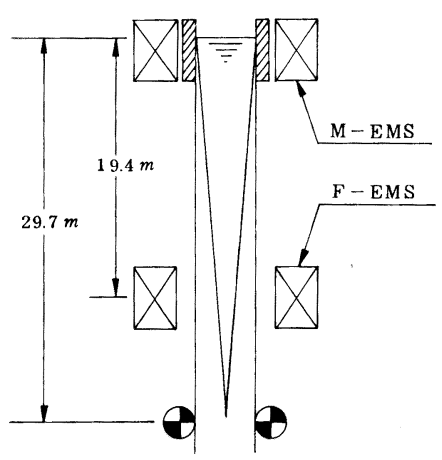

Fig 1. Schematic diagram of coil position

Table 2. Composition of heats (wt \%)

\begin{tabular}{|c|c|c|c|c|c|}
\hline $\mathrm{C}$ & $\mathrm{Si}$ & $\mathrm{Mn}$ & $\mathrm{P}$ & $\mathrm{S}$ & $\mathrm{Sol} . \mathrm{A} \ell$ \\
\hline 0.23 & 0.29 & 0.22 & 0.027 & 0.020 & 0.026 \\
\hline
\end{tabular}

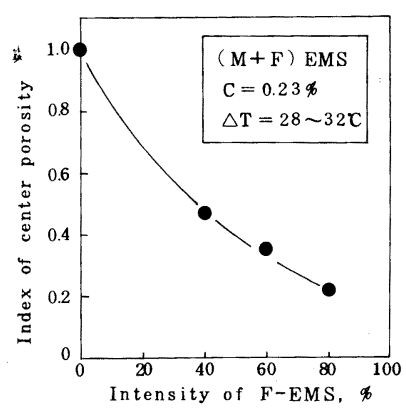

Fig 2. Relation between F-EMS and center porosity

〈交献〉1)田口ら；鉄と鋼 69(1983)S 272

2)水上ら，3）北川5; 本講演大会発表予定 
' $84-\mathrm{S} 280$

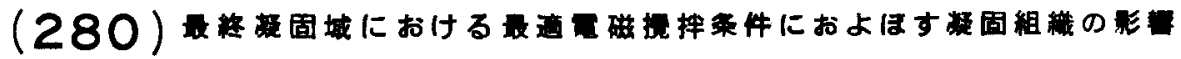

川崎制(株)技術研究所

\author{
○鈴木健一郎 \\ 中西恭二
}

村田婜治

宮川昌治

1. 緒 言

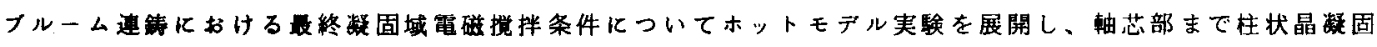

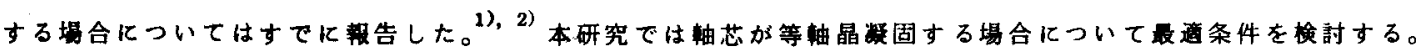

2. 実験方法

基本的には前報 ${ }^{1), 2)}$ と同じである。(Fig. 1)。本実糇では補

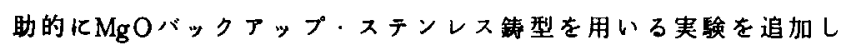
ている3)。なお、C $0.50, \mathrm{Si} 0.25, \mathrm{Mn} 0.90, \mathrm{P} 0.05$,

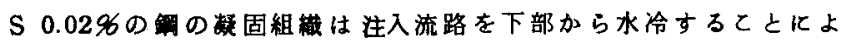

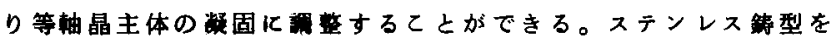

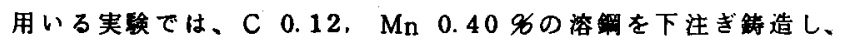
Fig.1 中の水平旋回コイルにより磁擋拌を行なった。

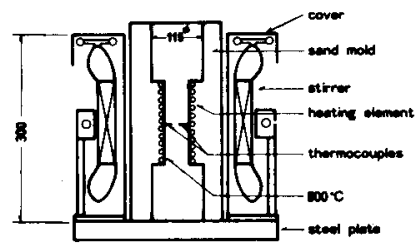

3. 実騃結果とその检討

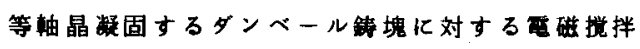
の効果をPhoto.1亿示す。住状晶群固鋳塊之異なり、 注入完了後 1 分程度加らの連繶港柈では湌化溶故

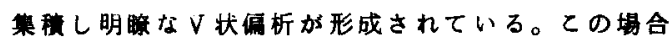
E M S 印加時汇固相先朔より内側飞存在するルルク

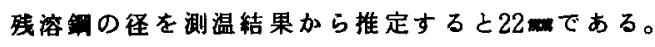
一方、V偏析が分散しているE80のヒートは、EMS 印加時のパルク线溶鍢の往は同じであるが、バルク

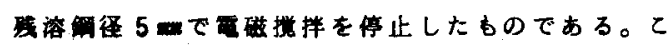

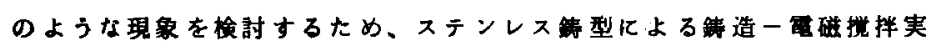

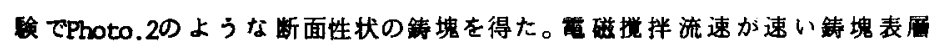

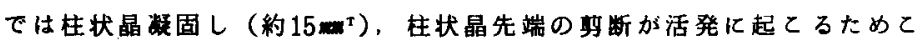
れより内側では等轴晶准固している。注目すべきは、等軸晶固域での

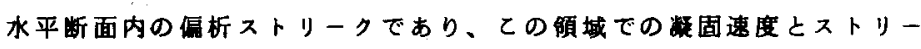
クの角度加方等軸晶片をともなう残溶銅の水平旋回速度を推定し20 然 の值を得た。一方、このような偏析ストリークは固相事0.70以上の湍化 溶成組成效応するとよ゙マクロアナライザー分析によりわかってい

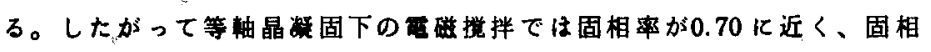
Experimental apparatus and typical example of dimensions of small ingot

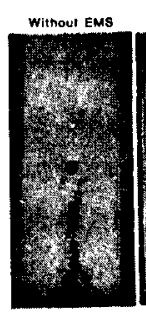

Ees

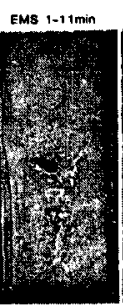

Ere

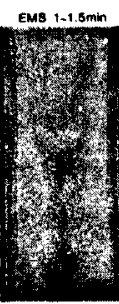

EEO

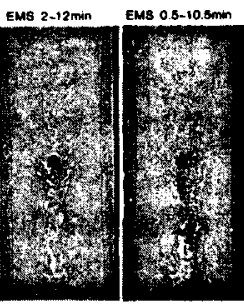

E\&1

$30 \mathrm{~mm}$

Photo.1 Influence of Stirring Mode on Solldified Structures of Small ingots

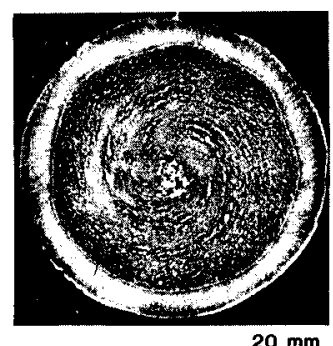

$20 \mathrm{~mm}$

Photo. 2 Segregation streaks observed in a small ingot stirred electromagnetically

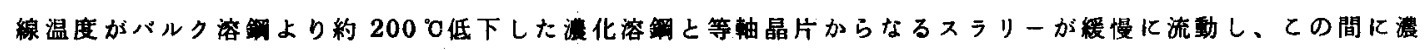

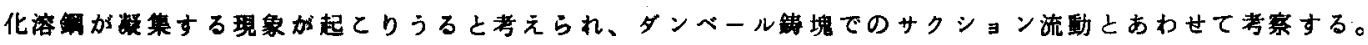
4. 文献；1），2）著者ら：鉄之筬 68（1982） 875，69（1983）963，3）著者ら：本大会講演予定 


\section{（281）静磁場通電方式電磁擋拌の負偏析層抑制効果}

住友金属工業搳) 中央技術研究所 0 小林 純夫

和歌山製鉄所友野宏, 人見康雄

I. 緒言 誘導方式の溶鋼電磁擋拌を行なうと負偏析層（ホワイトバンド：WB）代生成され, 強度 のW B は鋼の品質上好ましくない。W B の生成には乱流拡散が主要な役割をなしているが, 静磁場通電 方式電磁擋拌 (C-EMS $)^{2)}$ 場合, 直流磁場には乱流抑制効果があるため誘導方式電磁擋拌 (I-EMS) に くらへ負偏析度が小さいと予想され, 事実小さいと思われる結果が得られている。しかし, 従来の比較 は, 異なる連鋳機間でなされたものであり，厳密なものではなかった。今回，同一連鋳機で両者の比較 を行なう機会を得たので結果を報告する。

II. 実験内容 $370 \times 600$ ブルーム連鋳機を対象とし，Fig.1 亿示す二種の擋拌実験を行なった。擋 拌装置中心位置は，いずれもメニスカス下 $1.9 \mathrm{~m}$ で同一とし，一定の鋳込速度の下で擋拌強度と等軸晶 率, WB部における実効分配係数 Ke を求め, 擋拌方式の差を比較した。用いた鋼の成分をTable 1 に 示す。

III. 結果得られた結果をFig.2に示す。1）等軸晶率は, 両方式とも擋拌強度に応じて増加し, 最 大 $50 \%$ 程度が得られた。2） Keは，I-EMS の場合擋拌強度を增すにつれて低下し，得られた最小 值は, $\operatorname{Ke}[C] \cong 0.8, \operatorname{Ke}[P] \cong 0.7$ であった。一方, $C-E M S$ の場合は $\operatorname{Ke}[C] \cong \operatorname{Ke}[P] \cong 0.95$ であり， 擋拌強度にあまり依存しない。 Ke と等軸晶率の関係をFig. 3 亿示す。

N. 結論 C-EMSは I-EMSにくらべ軽微なW B で同等の等軸晶率を得るととができ, 有利な電磁 擋拌法であるととが明きらかになった。

Table 1. Chemical composition of steel

\begin{tabular}{|c|c|c|c|c|}
\hline $\mathrm{C}$ & $\mathrm{Mn}$ & $\mathrm{Si}$ & $\mathrm{P}$ & $\mathrm{S}$ \\
\hline$\sim 0.45$ & $\sim 0.80$ & $\sim 0.20$ & $\sim 0.02$ & $\sim 0.015$ \\
\hline
\end{tabular}
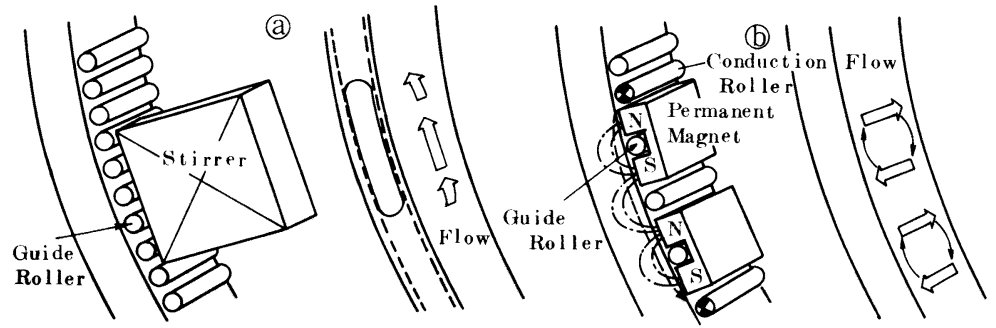

Fig. 1. EMS Methods; (a) I-EMS (1) C-EMS

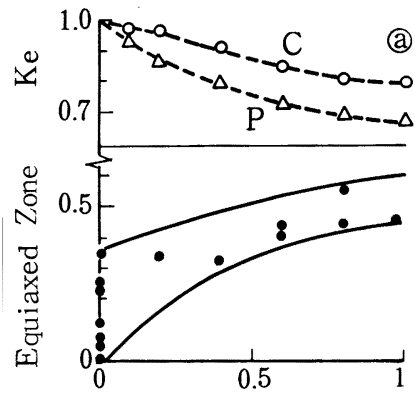

Stirring Intesity

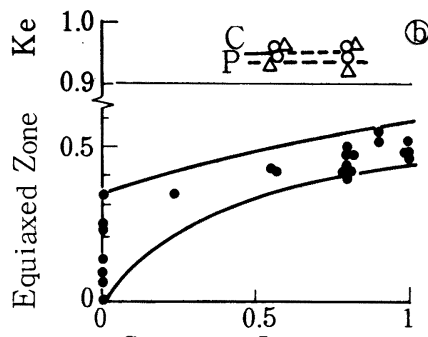

Stirring Intesity

Fig. 2. Ef fects of EMS ; (a) I-EMS, (b) C-EMS

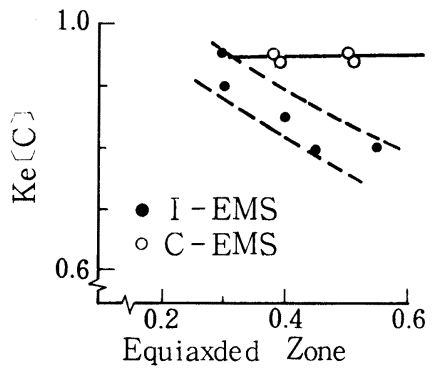

Fig. 3. Ke vs. Equiaxed Zone

参考文献 1)高橋ら; 鉄と鋼, 61 (1975), 2198, 2) T. Shraiwa et al ; Sumi tomo Search, (1979), 97 3) W.Murgatroyd ; Phy 1. Mag. 44 (1953), 1378, 4) C.Lock ; Proc. Roy. Soc. Ser. A, 203 (1955), $105,5)$ 中谷ら; 鉄と鋼, 67 (1981), 247 
' $84-\mathrm{S} 282$

（2８2）新 X線マイクロアナライザーによる連鋳鋳片の点状偏析評価法の検討

新日本製鐵(株) 第三技術研究所。福田義盛溝口庄三

第一技術研究所松宮徹浜田広樹宮崎武志

佐々木礼二

\section{1. 緒 言}

連鋳鋳片の中心近傍における点状偏析は，水素誘起割れ，Z空枠割れ等の大をな阻害要因となってい る。このよらな偏析の分析機器として，X線マイクロアナライザー（EPMA）と電算機を組み合わせた $\mathrm{CMA}^{(1)}$ ( Computer aided Micro Analyzer) がある。そとで, 今回は点状偏析の評価飞必要な測定条件 の検討を行ったので報告する。

\section{2. 测定条件，検討項目}

供試材は，鋳片幅方向中央 L 断面上で中心偏析部を含む50 mm 角 の部分を解析の対象とした。測定視野は, Fig. 1 亿示すよらに中心 偏析の最悪部 $5 \times 5 \mathrm{~mm}^{2}$ を共通にもつ部分を選び, 各ビーム径毎に $\mathrm{P}$, $\mathrm{Mn}$ の濃度を測定した。測定結果に基づんて，i）測定視野の影響,

ii) 測定ビーム径の影響，iii）X線照射時間の影響，につらて検討した。

3. 結果亡考察

(1) Fig.1亿示すような各ビーム径毎の視野で分析点数を 25 万点とし た場合のMnの偏析面積率とビーム径の関係を各ビーム径毎に Fig. 2 亿示 す。ビーム径が大をくなるほぼ視野が広くなるため高濃度域の占める割

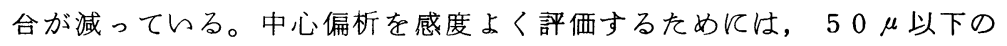
ビーム径で中心部を測定する必要がある。

(2) Photo.1は, 中心偏析最悪部の同一視野 $5 \times 5 \mathrm{~mm}^{2}$ をビーム径 10,50 , $100 \mu$ で測定した時の Mn の偏析面積像を比較したものである。10 ビーム径では, 影像がシャープで偏析の輪郭が明確であるが, 50 $100 \mu$ ビーム径が大をくなると微細構造が不明確となる。

(3) $10 \mu$ ビーム径では鋼中 の $\mathrm{CaS}, \mathrm{MnS}$ 等の介在物 が判別でをる。

(4) C M A の測定誤差は, (1)式で表わされ電子線の照 射時間を長くする程向上す る。照射時間が短くなると

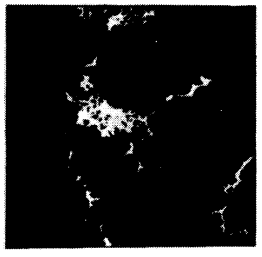

$10 \mu$

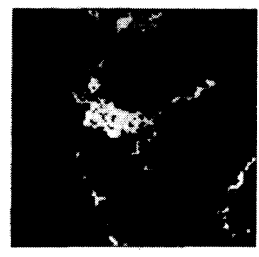

$50 \mu$

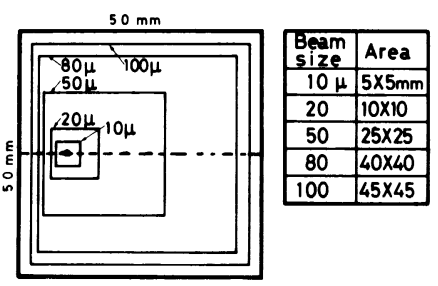

Fig. 1 Area of measurement.

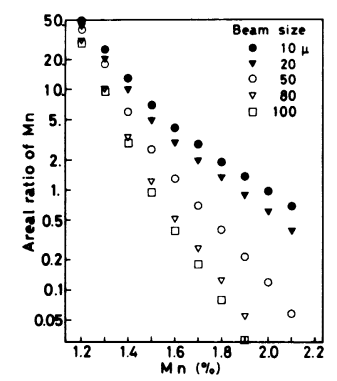

Fig. 2 Aroal ratio of Yn sogrogation.

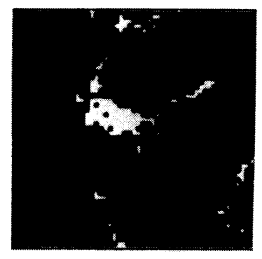

$100 \mu$

Photo.l Mn-segregation image at the conter line of CC slab.

誤差が大をく偏析状態を明確に現わさない。濃度 1 \%に対し $\sigma<0.05$ とするには，照射時間が $50 \mathrm{msec}$ 必要である。特に低燐鋼を評価する場合の照射時間は, $100 \mathrm{~m} \mathrm{sec}$ 必要である。

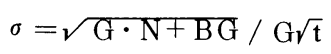

\section{$\mathrm{G}$; 濃度 1 \% 当りの傾を}

B G ; バッククランンド值 $\mathrm{t}$ ；照射時間 $(\mathrm{m} \mathrm{sec})$

4. まとめ

中心偏析部の二次元定量分析を行ら場合，調査目的に応じて測定視野，ビーム径，電子線の照射時間 等の適正条件を選択する必要がある。

参考文献 (1) 田口, 浜口, 釜: 昭和 56 年度日本金属学会秋期大会ンンポシウム講演 p. 89 
（283）水島製鉄所における新分析計算機システム

川崎製鉄侏 水島製鉄所

○杉原孝志 斉藤啓二 畑 俊彦 三浦 洋

(侏)島津製作所福田治郎今村直樹

1. 緒言 水島製鉄所における従来の分析計算機システムは分析専用計算機で複数の分析機器を集中制 御し, 含有量算出, 各工場へのデータ伝送を行っていた。今回，高炉，転炬などの操業管理に必要な分 析機器を有機的にリンクし, さらに粉体試料については前処理から各工場への伝送までの一連のト一タ ル処理をコンピュータ化した。こてでは，てのシステムの一部であり，新しく考案した粉体試料の試料 成型を含む全自動分析設備を中心に報告する。

2. 新分析システムの概要

2.1 システム構成 新システムは効率化を図るため含有量計算機と情報処理計算機を分離した機能 分散・機器分散方式を採用し, 各分析機器は原則として 1 台の含有量計算機と接続して分析処理および 情報処理が同時に行えるようにした。その構成を Fig.1に示す。ハードウエアの特徴は入出力速度を向上 させるために送受信に光データハイウエイを，炉中 分析結果の報告に新しく音声出力機構を装備したて とである。またソフトウエアの特徴は C R T に分析 命令，分析データなど必要情報をすべて表示し，タ イプライターを用いないペーパレスシステムを採用 したこと，精度管理，正確さ管理などもオンライン によるシステム化を図り信頼性を向上させたととで ある。

2.2 全自動分析設備 試料調製が煩雑で自動化 が困難とされていた粉体試料の分析を試料投入から 含有量算出まで全てを自動化した。設備はFig.2 に示すように試料粉砕機, 鉄片除去装置, プレ ス成型機, けい光X線分析装置および含有量計 算機から構成されている。乙の設備の特徵は従 来のものに比し, 粗粉砕装置を有しているとと, 同一粉砕機で異種の試料が調製できるように試 料の污染を考え固体洗材による洗净機構を設け たこと，および長期安定稼動のため微粉ダスト による分析装置污染防止用のサンプルホルダー 吸引クリーナを新しく設けたてとである。

3. まとめ 新分析システムの採用により分析 の作業性, 信頼性を大巾に向上させることがで きた。また粉体試料の分析を自動化することに より効率化，作業環境の改善を図った。微粉ダ ストによる真空度低下対策を講ずることにより 自動装置として長期間安定稼動が可能となった。

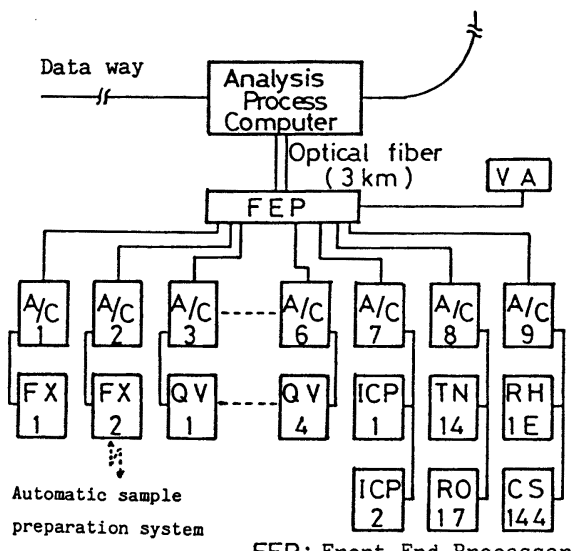

FEP: Front End Processor

Fig.1 Analysis computer system

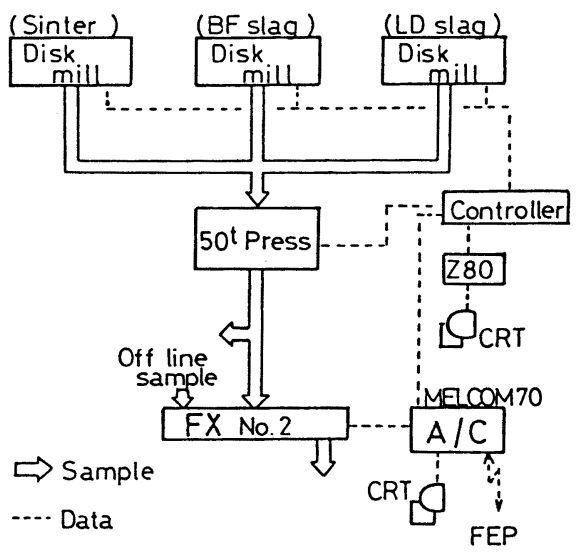

Fig.2 Automatic X-ray fluorescence analysis system

参考文献 1)遠藤 : 第 16 回西山記念技術講座 ( 1972) P.71 
1. 緒 言

ガラスビード法による鉄鉱石の蛍光X線分析における共存元素補正は，理論上必要とされることが確 認されているが, 現行 JISにおいては事実上補正の不要な元素を対象としている。本報においては， でに理論計算および実験によって確認した次の各項目を考慮した補正法の鉄分定量に実施し，良好な結 果を得た。現在までの確認項目は，

（1）基準二元検量線は仮想 $\mathrm{Fe}-\mathrm{O}$ 二元系を用い, $\mathrm{O}$ と不純元素との置換として理論強度補正を行うと とにより共存元素補正が可能である。

(2) ガラスビード中の Fe はすべて第二酸化鉄として存在する。(メスバゥア分析 $)^{2)}$

(3) $\mathrm{Fe}$ の酸化による増量, 脱水による減量は重量変化として求められる。

また，ての方法の延長として合成試薬ビードによっても補正の効果を推定するてとが可能となった。

2. 実 験

実験条件はTable 1 亿示す。

補正式は

$$
\text { I cor. }\left(F_{e} \mathrm{~K}_{\alpha}\right)=\mathrm{Iobs} .\left(\mathrm{FeK}_{\alpha}\right)\left(1+\sum_{\mathrm{j}} \mathrm{Aj} \cdot \mathrm{Wj}_{\mathrm{j}}\right)
$$

で表し，I cor., I obs.はそれぞれ補正，測定強度，Ajは補 正係数,W は不純物の重量分比である。用いたAjをTable 2 に 示す。Fig. 1 亿補正結果を図示する。
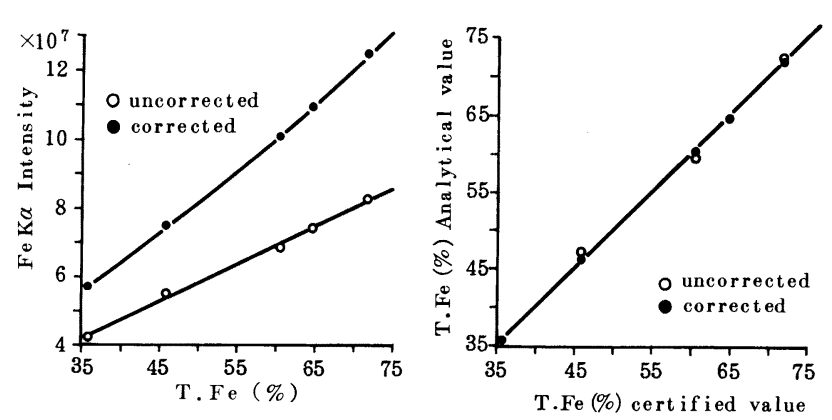

Table 1 Experimental Conditions

\begin{tabular}{|c|c|}
\hline Apparatus & Shimadzu VXQ-150 \\
\hline Excitation & $\mathrm{Rh}, 40 \mathrm{kVp}-70 \mathrm{~mA}$ \\
\hline Crystal & $\mathrm{LiF}$ \\
\hline Detector & $\mathrm{Kr}$ Mult. \\
\hline Measuring time & $75 \mathrm{sec}$ \\
\hline Flux : Sample & $\mathrm{Na}_{2} \mathrm{~B}_{4} \mathrm{O}_{7}: \mathrm{Sample}=10: 1$ \\
\hline Drying (Sample) & $105^{\circ} \mathrm{C} \times 2 \mathrm{~h}$ \\
\hline Fusing & $1000^{\circ} \mathrm{C} \times 15 \mathrm{~h}$ \\
\hline
\end{tabular}

Table 2 Intensity Correction Factors for $\mathrm{FeK} \alpha, \mathrm{Aj}$

\begin{tabular}{|c|c|c|c|c|c|c|c|}
\hline $\mathrm{MgO}$ & $\mathrm{Al}_{2} \mathrm{O}_{3}$ & $\mathrm{~S} \mathrm{iO}_{2}$ & $\mathrm{P}$ & $\mathrm{CaO}$ & $\mathrm{TiO}_{2}$ & $\mathrm{~V}_{2} \mathrm{O}_{5}$ & $\mathrm{MnO}$ \\
\hline 0.079 & 0.095 & 0.110 & 0.300 & 0.533 & 0.593 & $\mathbf{0 . 6 3 0}$ & 0.238 \\
\hline
\end{tabular}

Fig. 1 Corrected Results of Iron Determination

3. 結 言

鉄鉱石の鉄分の蛍光X線分析に, 酸化による重量増加, 脱水による重量減を加味した理論強度補正定 量を行い, 未補正時の誤差 $\sigma_{\mathrm{d}}=0.93 \%$ から補正後 $\sigma_{\mathrm{d}}=0.21 \%$ に向上した。

引用文献 1） 藤野他, 鉄之鋼, 66（1980） 2077

2）藤野他, 鉄と鋼，68（1982）S 307 


\section{（285）ガラスヒーード蛍光 X 線分析法における散乱 X 線の補正}

' $84-$ S 285

川崎製鉄侏技術研究所

$$
\begin{array}{rlll}
\text { 安 } & \text { 部 } & \text { 廣 } \\
\text { ○安 } & \text { 井 } & \text { 規 } \\
\text { 今 } \\
\text { 今 } & \text { 太久次 }
\end{array}
$$

\section{1. まえかき}

カララヒヒード篮光 $\mathrm{X}$ 線分析法において重元素については含有率が低くなると極端に分析精度が悪くなるといら 問題があった。とのためにスキャニングタイプ螢光 X線分析装置を用いて種々検討し、その原因が試料の組成の 差に上る散乱 X 線（主としてコンプトン散乱）強度の変動によるすのであるととをつをとめ、回折位置近傍のバ ックグラゥンド(以下B G といら)補正により、分析精度を著しく改善させた。 ${ }^{1}$ ) しかしの方法は一般に現 場などで広く使用されているマルチチャンネルタイプの装置には適用できないのて、、回はその置を対象に簡 単迅速に実施でさる補正方法を検討した。

\section{2. 実験方法}

B G の変動は重なり補正として取报えるが、補正定量法はまだ一般に採用されていないので各元素の測定位 置におけるB G 強度を求めて補正する方法を考えた。Fig. 1 亿鉄鉱石カラスビード試料の螢光 $\mathrm{x}$ 線回折図形 を示す。りま試料の組成が異なると（a)の位置でる（b)の位置 でもB G 強度は変化するが、しかしその比をとるとほほ一定 の值になる。従ってピークの重なりのない適当な位置で B G 強度を測定すれば、次式から各元素の測定位置でのB G 強度 が求まり、補正ができる。

$$
\operatorname{Ic}(\mathrm{i})=\operatorname{In}(\mathrm{i})-\mathrm{K}(\mathrm{i}) \times \mathrm{I} \text { o }
$$

ここで、I I ( i ) : i 元素の補正後の螢光 X 線強度 I n ( i ) : i 元素の補正前の螢光 $X$ 線強度 I o : 適当な回折角 $\theta$ o 亿おける強度 K(i)：i元素における補正係数。乙れはコンプト ン散乱量の最少ない酸化鉄( J S S 802-

\section{3. 実験結果}

3 ）を用いて実騒的に求める。

結果の一例としてFig. 2 およびFig. 3 亿 Cu の補正前後 の検量線を示す。またI。を Rh コンプトン線および鉄鉣石中 に含有されていない $\mathrm{Se} \cdot \mathrm{Nb}$ の測定位置(検出器) の強度とし たとをの補正結果 $\left(\sigma_{\mathrm{d}}\right)$ を、定量補正法および前報の結果とと

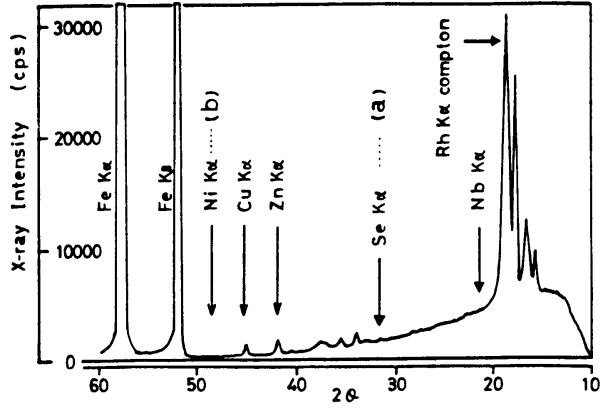

Fig. 1 Fluorescent X-ray Spectrum of glass bead disc.
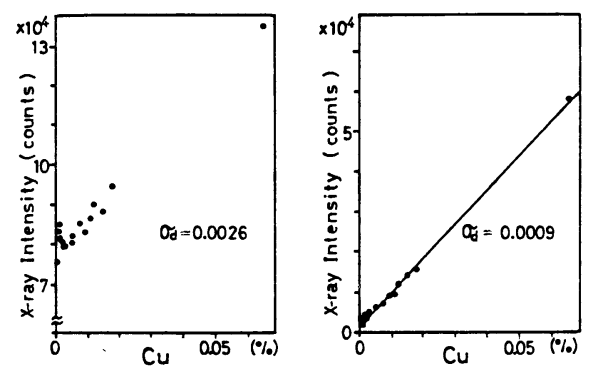

Fig. 2 Before correction Fig. 3 After correction

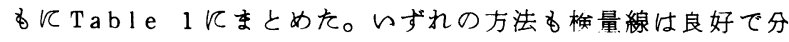
析精度す著しく改善できる。

\section{4. むすひ}

マルチチャンネル䖝光 $\mathrm{X}$ 線分析装固において、作業内容に応 じを適当なチャンネルでB G 強度を測定して補正すれば、重 元素の分析精度が改善できる。この補正法は鉄鉣石だけでなく、 粉体試料全般に適用でさる。

Table 1 Comparison of correction( $\sigma d)$

\begin{tabular}{|c|c|c|c|}
\hline $\begin{array}{c}\text { method for } \\
\text { correction }\end{array}$ & $\mathrm{Zn}$ & $\mathrm{Ni}$ & $\mathrm{Cu}$ \\
\hline not corrected & 0.0015 & 0.0015 & 0.0026 \\
\hline Ij correction & 0.0010 & 0.0010 & 0.0007 \\
\hline $\begin{array}{c}\text { direct masurement } \\
\text { of B.G. }\end{array}$ & 0.0011 & 0.0007 & 0.0009 \\
\hline $\begin{array}{c}\text { measurement of } \\
\mathrm{Rh} \mathrm{K}_{\alpha} \text { complon }\end{array}$ & 0.0008 & 0.0007 & 0.0008 \\
\hline $\begin{array}{c}\text { measurement of } \\
\text { Se } \mathrm{K \alpha}\end{array}$ & 0.0007 & 0.0007 & 0.0007 \\
\hline $\begin{array}{c}\text { measurement of } \\
\mathrm{Nb} \mathrm{K \alpha}\end{array}$ & 0.0006 & 0.0008 & 0.0009 \\
\hline
\end{tabular}

5. 参考文献 1 ) 安部忠廣, 安井規子：鉄と鋼, 68, (1982), S1052 
' $84-\mathrm{S} 286$

\section{（286）熱中性子放射化分析法による鉄鋼中の微量成分の定量}

（株）神戸製鋼所中央研究所。杉本公雄谷口政行成田貴一

1, 緒 㝘

原子炉の熱中性子を利用する放射化分析法は感度が極めて高く，微量分析の重要性が高まりつつある 現状において大きな可能性を持った分析法であるが, 特殊な設備を必要とし, 鉄鍋分析においてはあま り活用されていない。しかし鋼材の品質向上と高付加価值化が指向されるょうになり，それにつれて従 来あまり問題とされなかった極微量成分の高感度分析の要求が高まっている。

本研究では微量分析の定量下限を左右する試薬の污染を避けるとともに実用的な分析法を確立するた め, 試料に前処理を加えない非破壊分析の検討を行ない，化学分析法より高感度な分析条件を求めた。

\section{2 実 験 方 法}

1）切粉試料 $10 \mathrm{mg} \sim 1 \mathrm{~g}$ を薬包紙に包み原子炬の回転試料棚に入れて中性子照射する。 クトルの測定を行ない,コベル法により目的元素（核種）のピーク面積を求め, 標準試薬との比較検量 法により定量する。化学的な前処理を加えないので, 空試験值誤差が無視できる。

2) 短半堿期元素：立教大 T R I G A II 型炉（熱中性子束 $5 \times 10^{11} \mathrm{ncm}^{-2} \mathrm{sec} \mathrm{c}^{-1}$ ) で 4 分間照射 し, 3 分間冷却後, $\mathrm{Ge}$ 検出器つき 4000 チャンネル波高分析器で $と$ 線スペクトルを測定し,

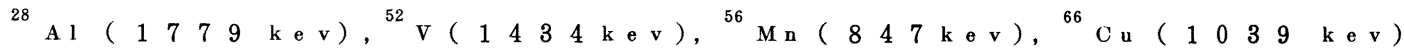
のピーク面積を求めた。

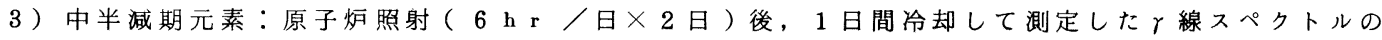

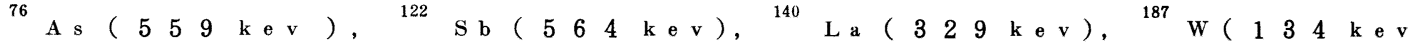
)のピーク面積を求めた。

4) 長半减期元素：原子炬照射（ $6 \mathrm{~h} \mathrm{r} /$ 日 $\times 2$ 日）後，16日間冷却して測定した の ${ }^{75} \mathrm{~S} \mathrm{e}(136 \mathrm{k} \mathrm{e} \mathrm{v}),{ }^{182} \mathrm{~T} \mathrm{a}\left(\begin{array}{llll}6 & 8 \mathrm{k} \mathrm{e} \mathrm{v}\end{array}\right)$ のピーク面積を求めた。

\section{3 実 験 結 果}

下表に本法による鉄鋼中の各元素の定量結果の例を化学分析法による值と比較して示す。化学分析法 の結果ともよく一致し, 微量域ではとくに本法の感度のすぐれているととがわかる。また定量精度につ いても良好な結果を得ており，十分に実用的な方法といえる。

\begin{tabular}{|c|c|c|c|c|c|c|c|c|c|c|c|c|c|c|c|c|c|c|c|}
\hline \multirow{2}{*}{$\mathrm{S}$ a m p le } & \multicolumn{2}{|c|}{ A 1} & \multicolumn{2}{|c|}{$\mathrm{M} \mathrm{n}$} & \multicolumn{2}{|c|}{$\mathrm{Cu}$} & \multicolumn{2}{|r|}{$\mathrm{V}$} & \multicolumn{2}{|c|}{ A s } & \multicolumn{2}{|c|}{$\mathrm{S} \mathrm{b}$} & \multicolumn{2}{|c|}{ W } & \multicolumn{2}{|c|}{ S e } & \multicolumn{2}{|c|}{$\mathrm{T} \mathbf{a}$} & \multirow{2}{*}{$\begin{array}{l}\mathrm{L} \text { a } \\
\mathrm{NA}\end{array}$} \\
\hline & $\mathrm{NA}$ & che & NA & che & $\mathrm{NA}$ & che & NA & che & $\mathrm{NA}$ & $\operatorname{che} \theta$ & N A & che & NA & che & NA & che & NA & che & \\
\hline I r o $n$ & 98 & 94 & 98 & 94 & 10 & 11 & 0.7 & $<1$ & 0.3 & $<2$ & 0.4 & $<1$ & 0.2 & $<1$ & 0.6 & $<5$ & 0.2 & $<2$ & 0.1 \\
\hline $1 *$ & 93 & 92 & 97 & 89 & 11 & 11 & 0.7 & $<1$ & 0.3 & $<2$ & 0.4 & $<1$ & 0.2 & $<1$ & 0.5 & $<5$ & 0.3 & $<2$ & 0.1 \\
\hline $\begin{array}{ll}\text { Pure } & \text { I r o n } \\
2 & \end{array}$ & - & - & - & - & $\begin{array}{l}4 \\
3 \\
\end{array}$ & $\begin{array}{l}4 \\
4 \\
\end{array}$ & $\begin{array}{l}0.03 \\
0.04\end{array}$ & $\begin{array}{l}<1 \\
<1 \\
\end{array}$ & $\begin{array}{l}0.1 \\
0.1\end{array}$ & $\begin{array}{l}<2 \\
<2 \\
\end{array}$ & $\begin{array}{l}0.1 \\
0.1 \\
\end{array}$ & $\begin{array}{r}<1 \\
<1 \\
\end{array}$ & $\begin{array}{ll}0.1 \\
0.1 \\
\end{array}$ & $\begin{array}{l}<1 \\
<1 \\
\end{array}$ & $\begin{array}{l}0.1 \\
0.2 \\
\end{array}$ & $\begin{array}{l}<5 \\
<5 \\
\end{array}$ & $\begin{array}{l}0.3 \\
0.2\end{array}$ & $\begin{array}{l}<2 \\
<2 \\
\end{array}$ & $\begin{array}{l}0.1 \\
0.1 \\
\end{array}$ \\
\hline $\begin{array}{l}\text { Low A110y } \\
\text { NBS }-361 \\
\end{array}$ & - & - & - & - & - & - & - & 一 & $\begin{array}{l}174 \\
164 \\
\end{array}$ & (170) & $\begin{array}{ll}4 & 2 \\
3 & 9 \\
\end{array}$ & $\begin{array}{c}(42) \\
38 \\
41\end{array}$ & - & - & \begin{tabular}{ll|}
3 & 3 \\
3 & 4 \\
\end{tabular} & (40) & - & - & $\begin{array}{l}9 \\
9\end{array}$ \\
\hline $\begin{array}{l}\text { Low Alloy } \\
\text { NBS }-363\end{array}$ & - & - & - & - & - & - & - & - & $\begin{array}{l}102 \\
103\end{array}$ & $(100)$ & $\begin{array}{ll}1 & 6 \\
1 & 5\end{array}$ & $\begin{array}{l}(20) \\
17 \\
17\end{array}$ & - & - & $\begin{array}{l}4 \\
4\end{array}$ & ( 2 ) & - & - & $\begin{array}{l}9 \\
9\end{array}$ \\
\hline
\end{tabular}

* Jss001-1; ( ) : Cert.Value; NA : This Method ; Che : Chemical Method 
新日本製鐵(侏) 第一技術研究所 中華人民共和国治金工業部
。黒沢文夫

田口勇

魏 緒佮

\section{1. 緒言}

ステンレス鋼中の析出相状態分析法の研究の一環として, 含窒素フェライト采ステンレス鋼 ( $\begin{array}{llll}4 & 3 & 0\end{array}$ 系) そB，A1の添加により析出する析出相の状態分析法および各析出相の析出挙動の検討を行った。

\section{2. 実験方法}

供試料の化学成分をTable 1 亿示す。試 料の熱処理は, $1250 \mathrm{C} \times 1 \mathrm{hr}, \mathrm{WQ}$ 後, $500 \sim 1200 \mathrm{C}$ の各温度で 3〜1020 min 保持した後水冷した。析出相の分析は 10
Table I Chemical Composition of steols (\%)

\begin{tabular}{|c|c|c|c|c|c|c|c|c|c|}
\hline & $\mathrm{C}$ & $\mathrm{Si}$ & $\mathrm{Mr}$ & $\mathrm{P}$ & $\mathrm{S}$ & $\mathrm{Al}$ & $\mathrm{N}$ & $\mathrm{B}$ & $\mathrm{Cr}$ \\
\hline $\mathrm{A}$ & 0.050 & 0.50 & 0.50 & 0.002 & 0.006 & 0.110 & 0.020 & 0.0042 & 16.5 \\
\hline $\mathrm{B}$ & 0.047 & 0.50 & 0.50 & 0.002 & 0.006 & 0.110 & 0.019 & 0.0091 & 16.5 \\
\hline $\mathrm{C}$ & 0.048 & 0.50 & 0.50 & 0.002 & 0.006 & 0.037 & 0.021 & 0.0093 & 16.5 \\
\hline
\end{tabular}

\%アセチルアセトンー1 \%テトラメチルアンモニウムクロラィドーメチルアルコール電解液による定電

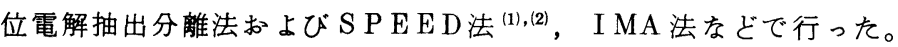

\section{3. 実験結果}

供試材について検討した結果について以下のようにまとめれる。

(1) 本供試料中には A $1 \mathrm{~N}, \mathrm{Cr}_{2} \mathrm{~N}$ および含ボロン炭 化物 ( ( Fe, $\left.\mathrm{Cr})_{23}(\mathrm{C}, \mathrm{B})_{6}\right)$ が同定された。

(2) $\mathrm{A} 1 \mathrm{~N}$ および $\mathrm{Cr}_{2} \mathrm{~N}$ の析出領域, 析出挙動の一例 をFig.1亿示した。Fig. 1 から, $\mathrm{Cr}_{2} \mathrm{~N}$ の析出は $500 \sim 700$ Cおよび $1000 \sim 1200$ Cで起とり,AIN の析出にともない 700 C 付近では减少する。AINは $700 \sim 1200$ Cの広ら範囲で析出する。

（3）供試料 A とつらてのA1Nの固溶一析出挙動を調 べ, $\log [\% \mathrm{~A} 1][\% \mathrm{~N}]$ と $1 / \mathrm{T}$ の関係をプロットした 結果をFig. 2 亿示した。Fig. 2 の結果より, $\log [\%$ $\mathrm{Al}][\% \mathrm{~N}]$ と $1 / \mathrm{T}$ との関係加次式を得た。

$$
\log \mathrm{K}=\log [\not \mathrm{Al}][\not \mathrm{N}]=-\frac{7997}{\mathrm{~T}}+2.82
$$

(4) 供試料の全てに含ボロン炭化物 $\left[(\mathrm{Fe}, \mathrm{Cr})_{23}\right.$ $\left.(\mathrm{C}, \mathrm{B})_{6}\right]$ が析出している。 $(\mathrm{Fe}, \mathrm{Cr})_{23}(\mathrm{C}, \mathrm{B})_{6}$ 中の $\mathrm{Fe}, \mathrm{Cr}, \mathrm{C}$ およ゙ $\mathrm{B} の$ 原子比は再加熱温度とと もに変化する。その代表的な組成は, 供試料 Aでは

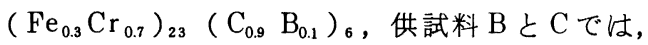
$\left(\mathrm{Fe}_{0.4} \mathrm{Cr}_{0.6}\right)_{23}\left(\mathrm{C}_{0.8} \mathrm{~B}_{0.2}\right)_{6}$ であった。

\section{参考文献}

（1）黒沢文夫, 田口 勇, 松本竜太郎：日本金属学会誌, 44 539 (1980)

（2）黒沢文夫, 田口勇, 谷野満: 日本金属学会会報, 20 377 (1981)

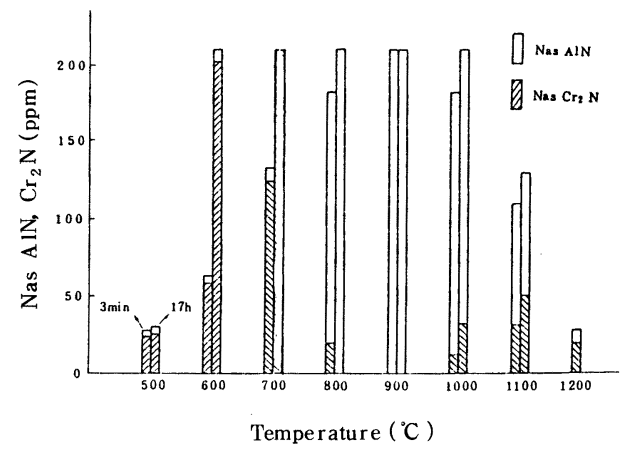

Fig. 1 Procipitation behavior of nitrides in stainless steel (A)

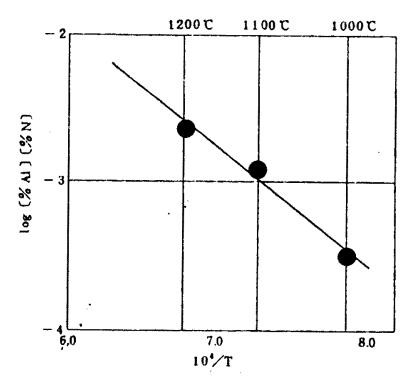

Fig.2 The solubility product of aluminum nitride in $\alpha-r$ regions 


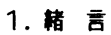

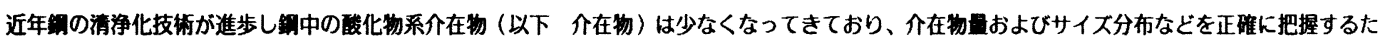

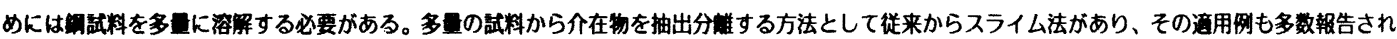

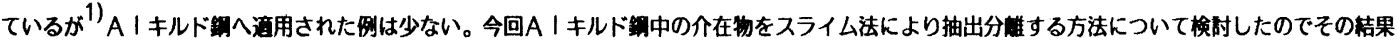
を啹告する。

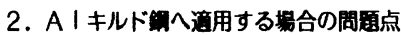

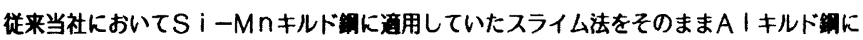
递用した籍合の同題点は以下のとうりである。

1)スライム四が多く、水笑法による介在物との分蜼が困蜼である。

2)抽出残渣中に存在する炭化物は非磁性であるためS i - Mn脱酸舒に通用していた磁気によ

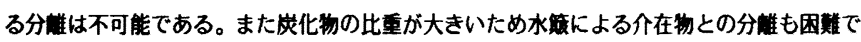
ある。

\section{3. 実筷方法}

これらの閤通点を解決するため、電解抽出および残渣処理の方法を以下のように変更し改善 を計った。

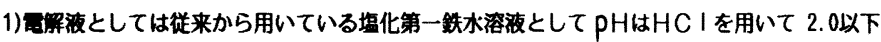
に保持する。

2)スライムと介在物とを分崔して抽出するために、電解䅦内にテフロン製のフィルターを設け 、铁イオンは通させ、介在物をフィルターで神集するようにする。(F i g. 1)

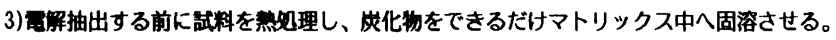
また抽出残渣中に存在する未固浴灰化物は化学処理により分解する。

\section{4. 実余結果}

1)雷解液の PH調整およびテフロンフィルターを用いることにより、抽出残渣中にはスライム はほとんど罗められない。

2)㛃処理により抽出残植中の疢化物は1/5 た娍少する。また残渣中の疢化物は化学処理によって 完全に分解できる。

3)疢化物の化学処理によって用中介在物であるアルミナクラスターはほとんど溶損することなく 抽出することができる。また抽出量の再現性も良好である。(Photo，1，Table．1）

5. 结 言

今回の模討によりA I キルド銈へのスライム法の道用が可能となった。本方法は大型銅塊の 品筫理に利用している。

\section{[考文献]}

1) 古田ら：柣と地 61 (1975) P2489

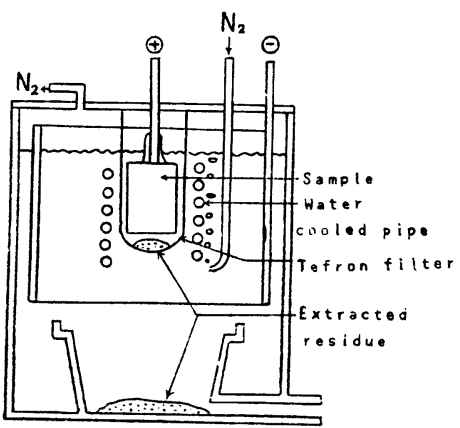

Fig.1 Apparatus for electrolytic extruction.

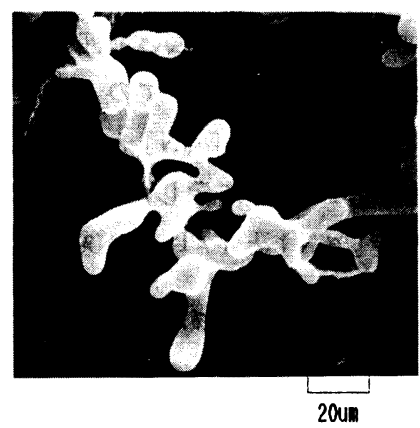

Photo.1 Extracted Inclusions.

Table.1 Amount of inclusions extracted from steel.

\begin{tabular}{|c|c|c|}
\hline Samp I e & 1 & 2 \\
\hline A & $0.037 \mathrm{~g} / \mathrm{kg}$ & $0.040 \mathrm{~g} / \mathrm{kg}$ \\
\hline B & $0.033 \mathrm{~g} / \mathrm{kg}$ & $0.031 \mathrm{~g} / \mathrm{kg}$ \\
\hline
\end{tabular}




\title{
（289）冷延鋼板表面及び鋼中の炭素分析
}

\author{
住友金属工業㑣 中央技術研究所 ${ }^{\circ}$ 藤野允克，小園弘已 \\ 和歌山製鉄所 吉田寛爾, 中村敏夫, 吉井達雄 \\ 九州電子金属(侏) \\ 稲永昭二
}

\section{1. 緒 言}

冷延鋼板に存在する炭素および炭素化合物は単に鋼板中に存在する炭素のみならず，表面に存在する 有機物や無定形炭素, グラファイトなどがあるてとが知られている。従来から行われていた分析対象は 鋼板中の成分炭素含有率であり，十分に洗涤した細片化された鋼片を使用し，酸素雲囲気にて溶融，燃 焼によって炭素を酸化し最終的に $\mathrm{CO}_{2}$ として定量するものであった。

しかしながら，鋼板の化成処理性，さらに耐食性の見地から表面に残留するカーボン（無定形炭素） 量を定量，管理する要求が生じ， $\mathrm{HC} 1$ 中でカーボン・スマッジを拭いとり，てれを酸化させ $\mathrm{CO}_{2}$ として 定量する方法が実用化された。この時の問題としては作業性が極めて悪いとと，有機物とカーボンとを 区別できないととがある。

本報告では炭素および有機物が，酸素䨌囲気中で燃焼する温度の異るととを利用した状態分析を行う ことにより, 同一の試料に存在する有機物污れ, 付着炭素分, 鋼中成分を別々に定量する装置を試作し, 実用化の見通しを得たので報告する。

\section{2. 装置および実験結果}

装置の概念図をFig. 1 亿示す。測定条件 をTable 1 にまとめた。また炭素の酸化と 温度との関係図をFig. 2 に示す。

Table 1. Operating Conditions

\begin{tabular}{|c|c|c|}
\hline & C in steel & Surface C \\
\hline $\begin{array}{c}\text { Sample } \\
\text { size }\end{array}$ & $\begin{array}{c}\phi 10 \mathrm{~mm} \text { 1 sheet } \\
(0.5 \sim 1.0 \mathrm{~g})\end{array}$ & $\begin{array}{c}\phi 15 \mathrm{~mm} \text { 3 sheet s } \\
(10.6 \mathrm{~cm})\end{array}$ \\
\hline $\begin{array}{c}\mathrm{O}_{2} \\
(l / \mathrm{min})\end{array}$ & 1 & 1 \\
\hline $\begin{array}{c}\text { Heating t ime } \\
(\mathrm{sec})\end{array}$ & 30 & 30 \\
\hline $\begin{array}{c}\text { Heating temp. } \\
\left({ }^{\circ} \mathrm{C}\right)\end{array}$ & 2000 & 600 \\
\hline Accelerator & W $2 \mathrm{~g}$ & - \\
\hline $\begin{array}{c}\text { Cal ibration } \\
\text { method }\end{array}$ & two point s & one point \\
\hline Range & $0 \sim 1000 \mathrm{ppm}$ & $0 \sim 800 \mathrm{mg} / \mathrm{m}^{2}$ \\
\hline
\end{tabular}

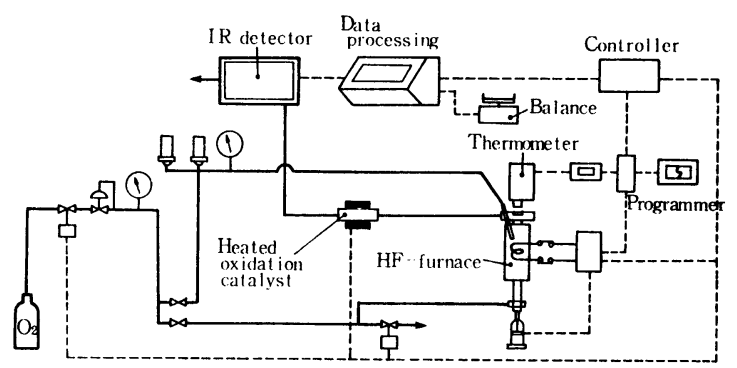

Fig. 1 Block Diagram of Carbon Analyzer

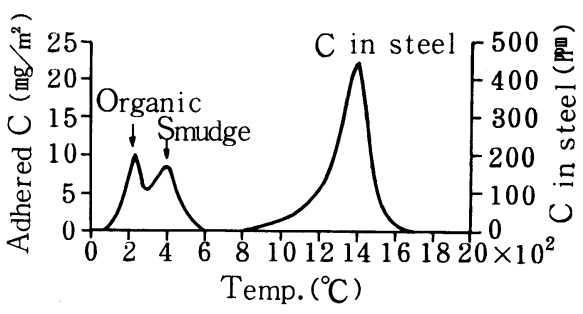

Fig. 2 Oxidized Carbon vs Temperature

3. 結 言

(1) 板状の打抜冷延鋼板を試料とする炭素分析計を試作し，付着有機物，無定形炭素，鋼中炭素を連

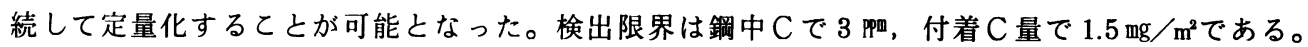

（2）本装置に使用するととにより，バックグラウンドが装置への吸着炭化物と，燃焼用 $\mathrm{O}_{2}$ ガス中の 炭化物が存在するととを見出した。

（3）冷間王延油の付着量管理への使用も可能であることから，焼鈍前及び焼鈍后の鋼板の品質管理用 に工場分析用として自動化を進めている。 
' $84-\mathrm{S} 290$

\section{（290）鏩中微量炭秦の分析}

住友金属工業株式会社 中央技術研究所猪熊康夫, ○落合 崇

I 緒 言

近年の高純度鋼の開発に伴い極微量成分を分析する必要が増えている。 鋼中炭素については $10 \mathrm{ppm}$ 水準までの分析が要求されているか，現在一般に使用されている高周波加熱燃焼一赤外線吸収分析法で は検出器の感度は十分にあるにもかかわらず，各種ブランクの管理が困難なために必要な分析精度が得 られていない。とのためブランク值の把握が容易な抵抗加熱炉燃焼法に電気伝導度検出器を付けて微 量炭素分析法の検討を行い，微量分析を行う場合の 2,3 の知見を得たので報告する。

II 実 験 方法

試料燃焼部と吸収セルはWösthoff 社製のCarmhomat のもの を用いた。Carmhomat の導電率測定方法は吸収液の導電率 測定セルと比較用の導電率測定セルとでKohlraush bridge を 作り，導電率の変化をサーボモータに連動したポテンショメー タで検出しているが，機械的な素子が入っているために感度を 上げるのは困難であった。そてで phase locked ampを用い る Dionex 社製 Ino chromatograph 用の導電率計を用いて吸収 セルの導電率を測定した。導電率計からの出力信号は $\mathrm{A} / \mathrm{D}$ コンバータを介してマイクロコンピュータに取り入れ、スムー ジングや微分のデータ処理を行った。

III 結 果

1. 燃焼ガスを吸収した時の導電率の変化はFig. 1 に示すようにベース ラインのシフト量で $\mathrm{CO}_{2}$ 量に対応する情報が得られる。 このシフ

ト量を求めやすくするために 25 点のスムージングを人れた微分信号 を求め, ピーク面積から炭素量を求めた結果， $1 \mu \mathrm{g}$ 以下まで十分読 取れる感度が得られた。

2. ショ糖標準溶液をガラスフィルターに付ける方法で検量線を作成し た結果，Fig. 2 に示すように良好な直線関係が得られた。

3. ブランクについては，分析する直前に試料ボートを空焼し，赤熱し

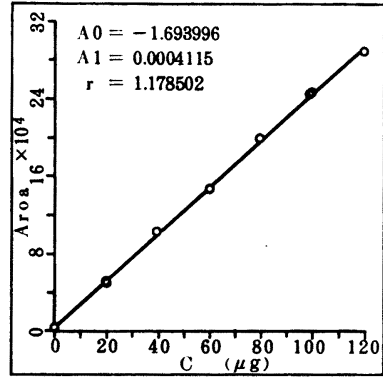

Fig. 2 Calibration curve of $\mathrm{C}$ with sucnrose sample た状態のボートに $\mathrm{Cu}$ 助然剤を入れるととによりブランク 值を $1 \mu \mathrm{g}$ 以下にできることを確認した。

4. 試料の付着物は $430^{\circ} \mathrm{C}$ 前後の低温部に試料ボートを置 くととにより Fig. 3 に示すように確認できる。との方法 で試料前処理法を検討した結果, 有機溶郕で洗浄したのち さらに $\mathrm{H}_{2} \mathrm{O}_{2}-\mathrm{HF}$ 系化学研磨液で処理するととにより付 着物が除去できることが判明した。

5. 本分析法で市販標準試料を分析した結果，大部分の試料 で標準值に対して数䧃低值となることが判明した。

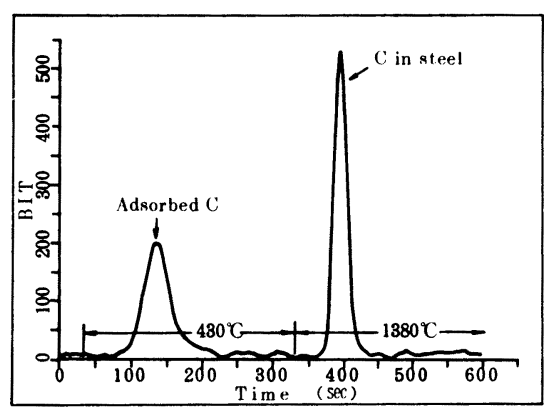

Fig. 3 Typical signal of adsorbed $\mathrm{C}$ and $C$ in steel 


\section{（29l）：二次イオン質量分析法による鋼中水素の分析}

' $84-\mathrm{S} 291$

新日本製鐵(株) 第一技術研究所。鈴木堅市大坪孝至

\section{1. 緒言}

S I MS は原理的に水素の分析が可能である。乙れまでにも Ti, Nb, Zr, V 金属中のHやSi Kイオン 注入されたHのS I M S に上る分析が検討 ${ }^{(1)}$ されている。鋼中の H は鋼材特性を支配する重要元素のひと つであるが，その濃度が上記金属に比較して非常飞低いためS I M S に上る分析は実用化されていない。 その大をな理由は，一次イオン中の不純物イオンや残留ガスの試料表面への吸着によるバックグランド がバルクの Hからの信号量に比較して非常に大をいためである。しかし, 最近は $\mathrm{C}_{\mathrm{s}}{ }^{+}$等の固体イオン源 や分析公の超高真空化の開発が進み，鋼中 $\mathrm{H}$ の分析も期待でをるようになった。そてで，H含有量が鋼 に比較して高い $\mathrm{Ti}$ 試料を使って H分析のための諸条件を検討してれに基づいて鋼中 $\mathrm{H}$ の分析を試みた。

\section{2. 実験}

装置は CAMECAの imsー3 f 用いた。排気系は一次イオン系が ターボ分子ポンプ (到達真空度 $2 \times 10^{-7}$ Torr ), 試料室がHe クライ オポンプ (同 $2 \times 10^{-9}$ Torr ) , 二次イオン分析系は二台のイオンポン プ (同 $4 \times 10^{-9}$ Torr ) である。一次イオンには $\mathrm{O}_{2}^{+}, \mathrm{N}_{2}^{+}$及び $\mathrm{C}_{\mathrm{s}}^{+}$を用 いたが，質量分離による純化は行わず直接照射した。 $\mathrm{O}_{2}{ }^{+}$及び $\mathrm{N}_{2}{ }^{+}$照 射時の試料室は $1 \sim 2 \times 10^{-8}$ Torrである。一次イオン量は $5 \mu \mathrm{A}_{\left(\mathrm{s}_{\mathrm{s}}^{+}\right.}^{+}$ は $8 \mu \mathrm{A}) て ゙ ~ 250 \times 250 \mu \mathrm{m}\left(\mathrm{C}_{\mathrm{s}}^{+}\right.$は $\left.500 \times 500 \mu \mathrm{m}\right)$ のラスタスキャ ンを行々, 中央部 $150 \mu \mathrm{m} \phi$ を分析した。 $\mathrm{Ti}$ は N BS 標準試料 ( 32 , $98,215 \mathrm{wt} . \mathrm{ppmH})$ を,ステンレス銓は $2.0 ， 2.4 ， 4.0$ 及び $4.4 \mathrm{wt}$. ppm Hのbのをアルミナバフ研摩して用いた。

\section{3. 結果亡考察}

(1) $\mathrm{Ti}$ での検討結果では，Hの二次イオンイールドは $\mathrm{H}^{-}$が高い。バッ ククランドは $\mathrm{N}_{2}^{+}$の場合が最も大をい。 $\mathrm{C}_{\mathrm{s}}^{+}$は $\mathrm{H}^{-}$のイールドを必ずし

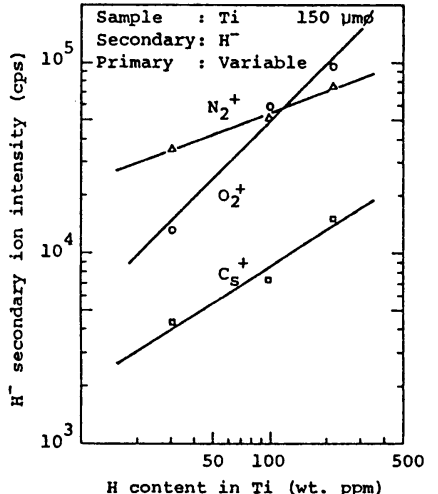

Figure 1 Effect of primary ion source on $\mathrm{H}^{-}$secondary ion intensity も大さくしないがバックグランドが小さく, 検出下限の低下 や分析精度の向上が期待できる(Fig. 1 )。

(2) ステンレス鋼中の $\mathrm{H}$ 分析結果は, 一次イオンが $\mathrm{O}_{2}^{+}$の場 合はばらつをが大をく、バックグランドレベルを測定してい る状態に近い。 $\mathrm{C}_{\mathrm{s}}^{+}$の場合は数 p p m 以下の $\mathrm{H}$ の定量が可能な ょうである(Fig. 2 )。

(3) $\mathrm{H}$ 分析の際の残留ガスによるバックグランドは $\mathrm{H}_{2}$ よりも $\mathrm{H}_{2} \mathrm{O}$ の影響が大さいが(1) , 本実験中の残留ガスの 90 \% 以上 は $\mathrm{H}_{2}$ であった。しかし一次イオン源に $\mathrm{O}_{2}, \mathrm{~N}_{2}$ のガスを使用 すると $\mathrm{H}_{2} \mathrm{O}$ 及び $\mathrm{CH}_{4}$ の分圧が高くなる。その点では $\mathrm{C}_{\mathbf{8}}{ }^{+}$は 効果があるが, 低合金鋼中のHの定量やミクロ解析のために さらに高真空化が望をれる。

文献 (1) C. W. Magee and E. M. Botnick：J. Vac. Sci. Technol. $\underline{19}, 47,(1981)$

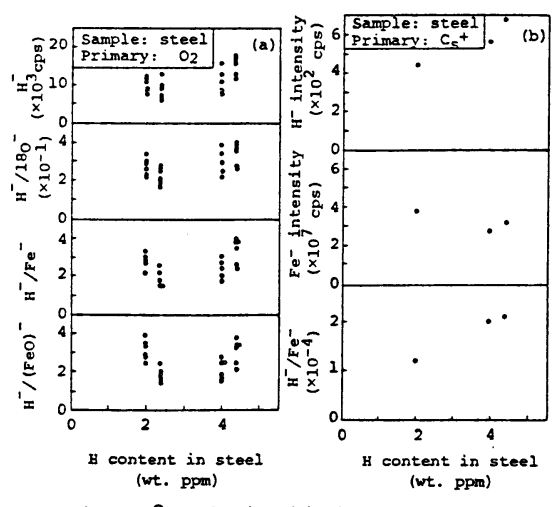

Figure 2 Relationship between $\mathrm{H}$ content in steel and secondary ion intensity / intensity ratio obtained by $\mathrm{O}_{2}+$ and $\mathrm{C}_{\mathrm{s}}{ }^{+}$ions 
'84- S 292

（292） オージェ定量分析におけるアパチャーの影霎

大同特殊鋼（株）中央研究所 ○江川篤雄，吉田鎮雄

高蔵製作所伊藤六仁

\section{1. 緒言}

オージェ電子分光法（以下AES）は、表面および界面の分析装置として種々の分野で使用されてい

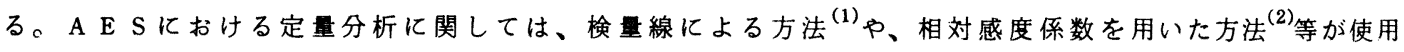
されている。しかし定量分析精度におよぼすアパチャ一の影響については不明確であり、以下その影響 について検討した結果を報告する。

\section{2. 実験条件およひ供試材}

測定に用いた装置は、P H I 社製 A E S ( Super SAM Model 590 )で、一次ビームの加速電圧、ビーム電 流、変調電圧、検出器電圧等の測定条件は固定とした。アパチャ一は 3 条件でてれによりエネルギー分 解能は $0.3 \% 、 0.6 \%$ およ゙ $1.2 \%$ と変化する。また定量補正計算はP H I 社の相対感度係数による方 法で行なった。測定に供した試料は、日本鉄鋼標準試料（J S S ） F e - C 系および蛍光 X 線分析用

( FXS ) Fe - N i 系の 2 元系である。また测定供試料はアルミ ナバフ研磨し、さらに污染元素の影響を少なくする為十分なス パッタリングを施した。なお定量に用いたオージェ電子エネル ギーはFe: $703 \mathrm{eV}, \mathrm{Ni}: 848 \mathrm{eV}, \mathrm{C}: 273 \mathrm{eV}$ である。

\section{3. 結 果}

(1) $\mathrm{Fe}-\mathrm{Ni}$ 系の测定結果を困 1 に示す。エネルギー分解能を $0.3 \sim 1.2 \%$ と変えてもオージェ分析値に差は無い。ま た化学分析值とあよく一致する。

(2) $\mathrm{Fe}-\mathrm{C}$ 系の測定結果を図 2 に示す。エネルギー分解能を $0.3 \sim 1.2 \%$ 変える事によりオージェ分析值は徐々に 高くなる。また化学分析値に対してあ変化する。

このことはアパチャーが広がる事による $\mathrm{Fe}$ の強度増大分に比 ベ、低エネルギー側であるCの強度増大分が大きく、近い電子 エネルギー間 ( $\mathrm{Fe}-\mathrm{Ni}$ 系)で定量する場合にはアパチャ一の影響 は小さく、高エネルギー（Fe）と低エネルギー（C）を含んだ場 合にはアパチャーの影響は大きい。従って、相対感度係数を用 いる場合は、この係数を求めたと同一アパチャーの測定では変 える必要は無いが、アパチャーを変えるかまたはアパチャーが 変っている場合は、相対感度係数を変えるかまたはオージェ電 子エネルギーレベルに対する感度補正が必要となる。

以上の検討結果之、さらに $\mathrm{Ag}, \mathrm{Fe}, \mathrm{Cr}$ 等純物質での検討およ び社内試料を蛍光 $\mathrm{X}$ 線分析し標準試料とした多元系についてす 検討を行ない、オージェ定量分析におけるアパチャ一の影響に ついて明らかにし、分析精度向上をはかることができた。

[参考文献] 1) L.E.Davis他; Handbook of AES (1976)

2）鈴木洋夫; 日本金属会報 14（1975), 173

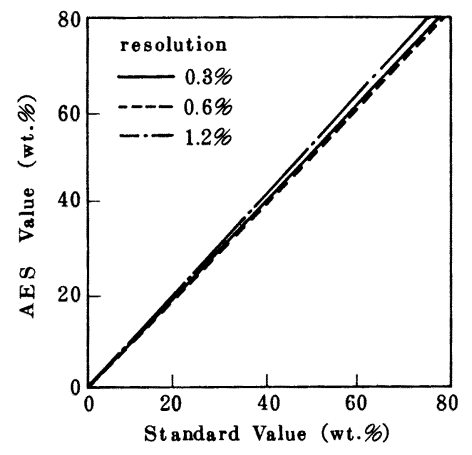

Fig. 1 Influence of resolution on AES analytical value of $\mathrm{Fe}-\mathrm{Ni}$

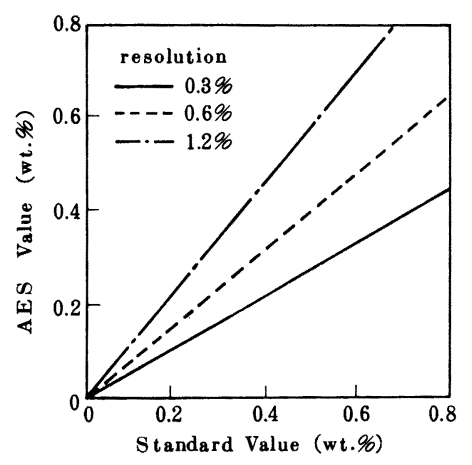

Fig. 2 Influence of resolution on $\mathrm{FES}-\mathrm{C}$ analytical value of 


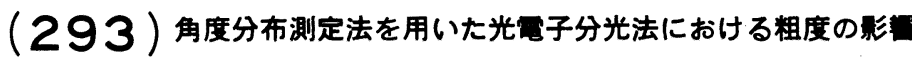

川崎製鉄技術研究所 $\bigcirc$ 羽根孝子, 角山浩三 大橋善治

\section{1. 緒害}

表面分析手法として、現在多種開発されているが、いずれる梁さ方 向の分析を行な5場合は、 $\mathrm{Ar}^{+}$イオン照射を用いる必要がある。乙の場 合、試料表面の化学状態の変化、例えば還元・脱水等が起とるととがあ り、その影慗を考虑しなければならない。そてて、Fadley らの検討し た ${ }^{1)}$ 光電子分光法における角度分布測定法に着目し、光電子の脱出梁さ を変えるととによって、表面〜 $50 \AA$ 程度の領城の梁さ方向の分布を推 定するととを考えた。しかし実際の試料では試料表面の粗度により、分 布に大をな差を生じるのて、その影繁を取り去る手法を検討した。

\section{2. 実跲}

使用した置は、V. G. Scientific社製 ESCA LAB-5て、 X 線入 射と電子線放出方向のなす角岋固定であるが、光電子脱出角 $\theta$ を変化で さる。用いた試料は、純 $\mathrm{Fe}$ をバフ研摩又は\#1500エメリー研摩した 上に $\mathrm{Cu}$ を極く薄く蒸着したすので、蒸着厚みの连ら試料による $\mathrm{Cu} / \mathrm{Fe}$ 强度比の角度分布を求加。又、T.F. S. 中 $\mathrm{Crox} / \mathrm{Crmet}$ 強度比の角 度分布を、 $\theta$ を $90^{\circ}$ から $15^{\circ}$ まで変化させて測定した。

\section{3.結果および考穹}

粗度の影検討に先立って厚みの差の影慗について検討した。そ の結果、

（1）蒸着した $\mathrm{cu}$ の厚みが増加しても $\mathrm{cu} / \mathrm{Fe}$ 比は、測定した範囲内 では $\theta$ とらす、一定の割合で增加する。

（2）粗度が異なる場合その影は、 $\cos ^{2} \theta て ゙$ 経騃的に補正てるる。 ことがわかった。

Fig.1はエメリ一研摩した純 $\mathrm{Fe}$ 上の $\mathrm{Cu}$ から得られた $\mathrm{Cu} / \mathrm{Fe} の$ 角度分布 $\mathrm{A}(\theta)$ と、バフ研后した様の試料から求めた分布 $\mathrm{B}(\theta)$ を示 したすのてある。粗度の影製を $\log \mathrm{A}(\theta) / \mathrm{B}(\theta)=\mathrm{C} \cos ^{2} \theta$ で補正する ととすに、蒸着厚みの差を考虑に入れるととによって図に見られるよう に、良好飞補正可能てある。

\section{4. 応用例}

本方法を、T.F. S. 表面酸化膜の状態解析に用いた結果をFig. 2 に示す。これらはいずれる同様の制離強度を持つが、補正前では粗度や 厚みの影繁を受けて複雑であるが、図中○印を基準にして補正を行なら と、表面届では C r がより酸化されているととが明瞭となる。この補正 法は、他の様々な試料に対してる有効に利用でる。

1 ) C. S. Fadley, Faraday. Discuss. Chem. Soc, 1976, 60

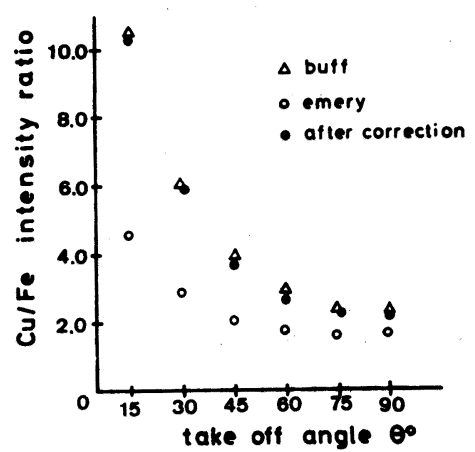

Fig. 1 Angular distributions of $\mathrm{Cu} / \mathrm{Fe}$ intensity ratio for different roughness
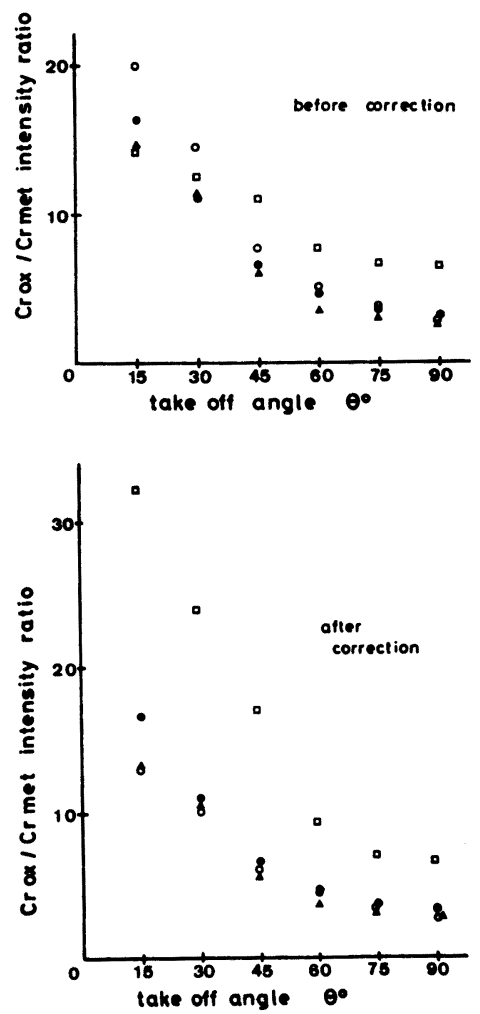

Fig. 2 Angular distributions of $\mathrm{Cr}$ oxide/Cr metal intensity ratio for oxide film in T.F.S 
' $84-\mathrm{S} 294$

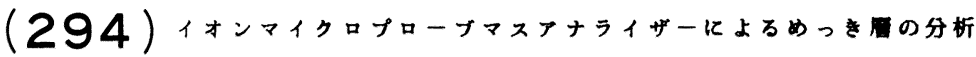

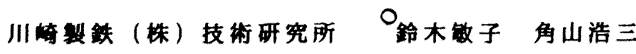

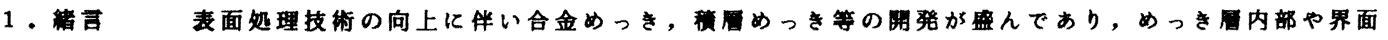
におけろ元来の分布を明らかにするととが重要となってきた。イオンマイクロプロープマスフナライザー(以下 I M M A ) は亮惑度であろうれに深さ方向の分解能が最も優れておりててれらの分析に浐している。今回は各種

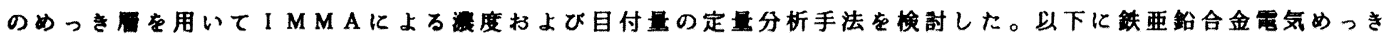
を例として赧告する。

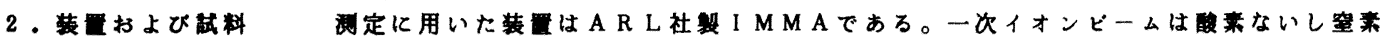

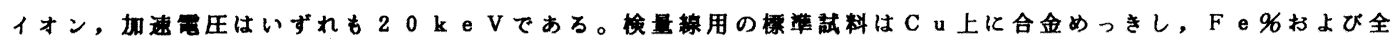
目付业は原子吸光法により求めた。 $\mathrm{F}$ e \%は $10 \sim 80 \%$ ある。

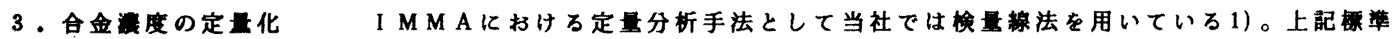

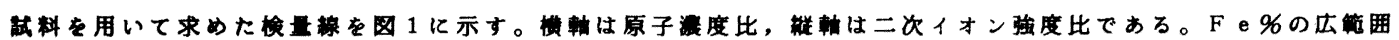
において良い直制性があり，鉄垔鉛合金電気めっき飞おいてはいずれの元来をマトリックスとしてもマトリック ス协果が無視できるととを示している。

4. 目付量の定量化深さ方向の分析におけるスパッタ一速度は，一次ビーム条件の他にターダットの重

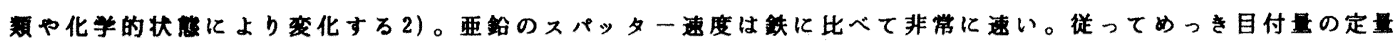
化を行なうためには，合金量の変化に伴うスパッタ一速度の変化をあらかしめ求めておく必要がる。铁要鉛合

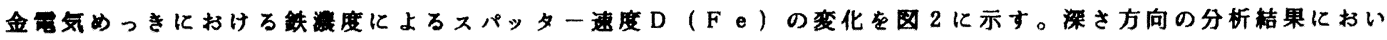

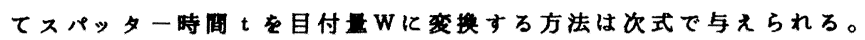

$$
W=\sum_{i=1}^{N} D_{i}(F e) \cdot\left(t_{i}-t_{i-1}\right) \cdot i_{p} / S
$$

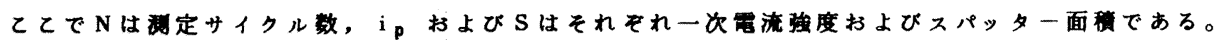

5 . 結果图3に上記の方法により解析した深さ方向の定量分析結果を示す。化学分析による結果はFe％

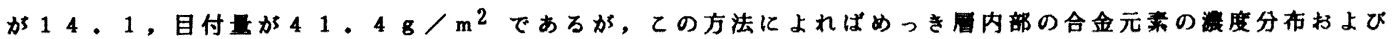
目付至が定至化できる。同漛な方法で他の合金めっきの解析も可能となった。

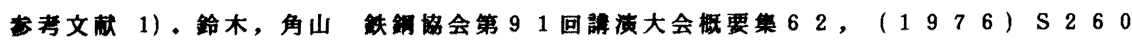

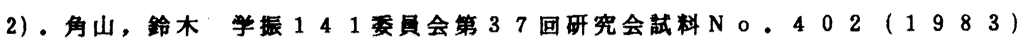
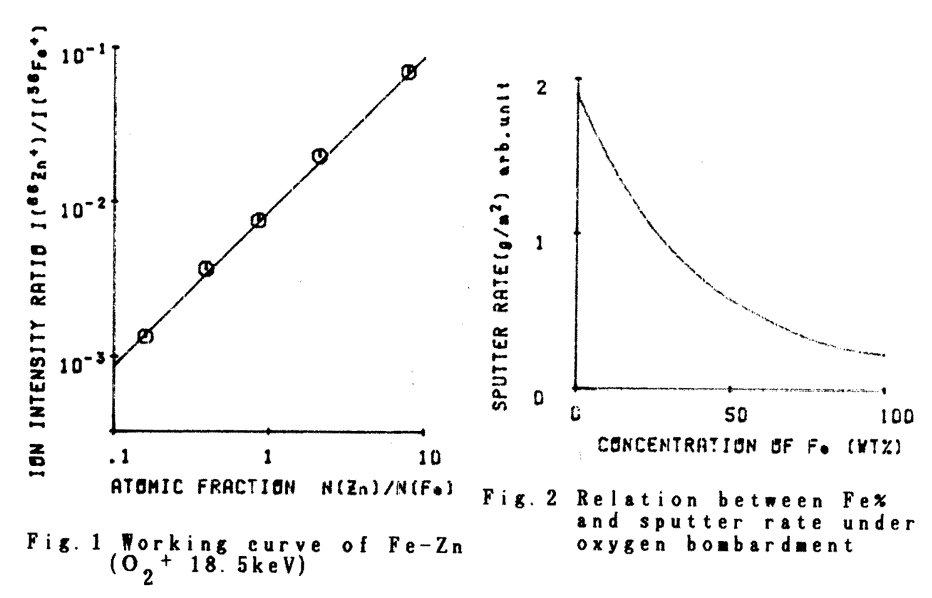
WEIGHT OF $Z_{n} F_{\theta} g / \mathrm{m}^{2}$

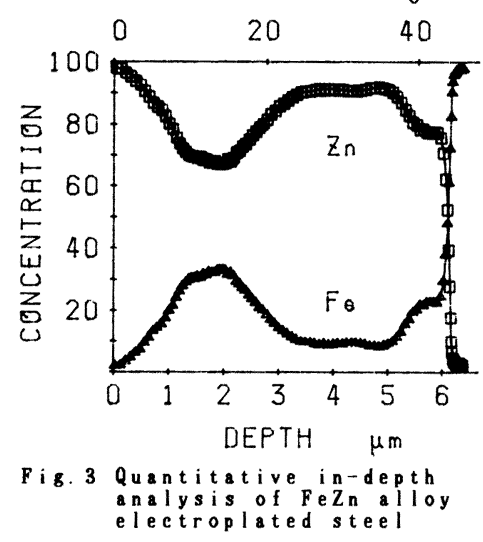


(グロー放電分光分析法に上る合金メッキ層の定量分析一1)

新日本製鐵(株) 第一技術研究所。鈴木堅市 西坂孝一 大坪孝至

\section{1. 緒 言}

最近の各種複合メッキ鋼板のメッキ層の分析に対して, 従来の化学的あるいは電気化学的手法では精

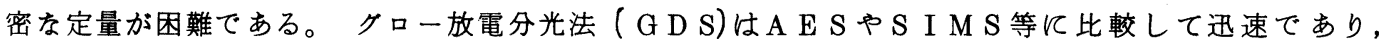
また，分析領域も数 $\mathrm{mm} \phi$ と大さいのでより平均的情報が得られること ${ }^{1)}$, 機器の操作及び保守が容易な こと等の理由で複雑なメッキ鋼板の管理分析に適している。筆者らはG D Sで得られるスパッタ時間一 光強度を, 深さ一濃度に変換し, 層別の組成及び目付量を求める方法を開発した。

2. 実験

GDSはRSV社（西独）製のANALYMAT 2504 を用いた。試 料は冷延鋼板飞組成及び目付量の異なる二元合金メッキ( $\mathrm{Zn}-\mathrm{Fe}$, $\mathrm{Zn}$ - $\mathrm{Ni}$ 等) したものを使った。GDSによるメッキ層の梁さ方向分 析結果から,メッキ層中央付近の平均強度をその組成における各元 素の光強度とし, また, メッキ成分の光強度が半减するまでの時間を メッキ層のスパッタに要する時間として各々求めた（Fig.1）。乙れ らの結果から二元系に利ける濃度一相対光強度（対純金属強度比, $\left.I_{i} / I_{i(100)}\right)$ 及び組成 ースパッタ速度の関係を求めた（Fig. 2, 3)。

\section{3. 濃度及びスパッタ速度の計算}

$i$ 元素の発光強度 $I_{i}$ から含有率 $C_{i}$ を求めるための定量補正式は (1)式で表わすてとができる。

$$
c_{i}=\frac{I_{i}}{I_{i(100)}} \cdot\left[1+\sum_{j} \alpha_{j}\left(c_{j}\right)\right]
$$

こてで $\alpha_{j}\left(c_{j}\right)$ はj元素によるマトリックス効果の補正項で, 二 元合金での実験結果から(2)式で溧近似でをる

$$
\alpha_{j}\left(c_{j}\right)=a_{i j} \cdot c_{j}^{3}+b_{i j} \cdot C_{j}^{2}+c_{i j} \cdot c_{j} \cdots \cdots
$$

未知試料の分析では $C$, が未知なためその初期値として相対光強度 を用いて近似し，各元素の含有率を繰返し計算して収劒值を求める。 各測定点の組成決定後，合金のスパッタ速度 $R_{0}$ を， $i$ 元素のスパッ 夕速度 $R_{i}$ から(3)式で補正して求める。

$$
R_{0}=R_{i}\left[1+\sum_{j} \beta_{j}\left(C_{j}\right)\right]
$$

補正項 $\beta_{j}(c$,$) は(2)式と同様に(4)式で近似する。(2), (4)式$

$$
\beta_{j}\left(C_{j}\right)=x_{i j} \cdot C_{j}{ }^{3}+y_{i j} \cdot C_{j}{ }_{j}^{2}+z_{i j} \cdot C_{j} \cdots \cdots
$$

の補正係数 $a, b, c$, 及び $x, y, z$ は Fig，2，3の二元系合金 メッキの実験結果から決定した。乙れらの計算は GDS のコンピュー ターで行い,メッキ層の深さー濃度プロファイル及び層別の組成, 目付量等が出力される。

文献

1）古主泰子, 大橋善治：鉄と鋼，69(1983) S1052

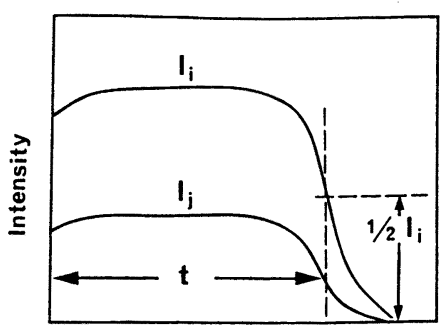

Sputtering time

Fig. 1 Parameters for quantitative analysis.

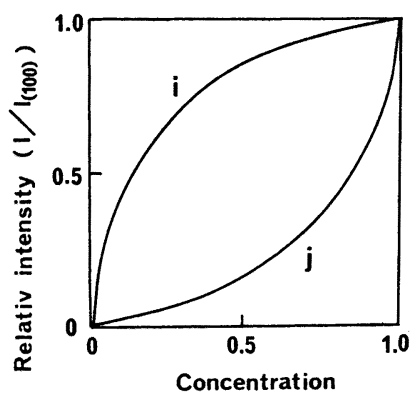

Fig. 2 Relationship between con centration and relative intensity.

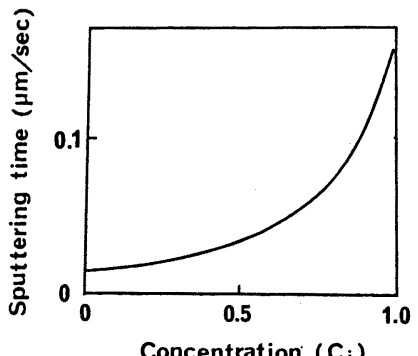

Fig. 3 Relationship between concentration and sputtering speed. 


\section{1. 緒 言}

G D S においてAｒイオンによるスパッタ効率およびスパッタされた原子の発光（励起）効率は物質 によって異なるてとが良く知られている。しかし, 多元合金では各構成元素のスパッタ効率および発光 効率がどのような関わりをもつか必ずしも明確でない。前報の共存元素㗀度による定量補正法は, 合金 てはてれらの值が干涉によって純物質の值からずれるてとも考虑した方法である。しかし, 前報の方法 は定量補正係数決定のために広い組成範囲て信頼性の高い基準試料が多数必要なとと, 補正係数決定の 手順が複雑であことなどの難点があるのて，てれらの点て容易な光強度積分方式を検討した。

\section{2. 装 遂}

実験にはRSV社のANAL YMAT 2500 を用いた。

原 理

合金中の i 元素の発光強度 I i は i 元素の単位時間当り のスパッタ量 $\Delta \mathrm{Wi}$ とスパッタ原子の発光効率の関数となる が, 一定放電条件のもとては発光効率は一定であると仮定 すると $\mathrm{i}$ 元素の発光強度はスパッタ速度（したがって のみの関数として表すととがでをる（1 式）。

$$
\mathrm{I} \mathrm{i}=\phi \cdot \Delta \mathrm{Wi} \cdot \mathrm{Ki}
$$

\section{$\phi:$ 装置関数}

$\mathrm{Ki}: \mathrm{i}$ 元素の発光効率に関する係数

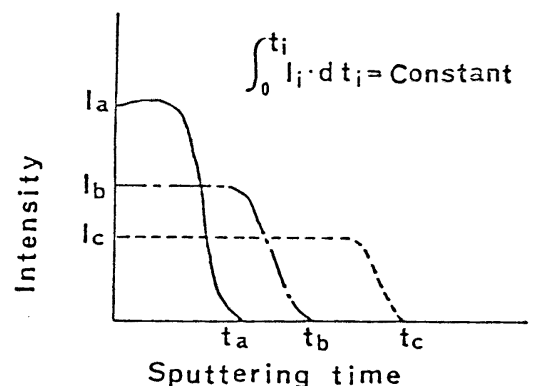

Fig.1 Relationship beiween inteno sity and sputtering time

したがってめ，Kiをあらかじめ実験值から求めておくことによって, 各元素の光強度の積分值から元素 ごとのスパッタ量を求めるととがてを（ 2 式）。乙の重量比から組成を求めるととがでをる。メッキ層 $\mathrm{Wi}=\mathrm{a} \int \mathrm{Ii} \cdot \mathrm{d} \mathrm{t}$

分析にあたっては, 測定プロファイルの各点におらて各元素の重量を求めててれから濃度および深さ に変換する。 $\mathrm{Fe}-\mathrm{Zn} 2$ 元・2 層メッキ材の分析では, 異なる層の境界判定に, 濃度一深さプロファイル の微分曲線を利用した（Fig.2）。

\section{3. 結 果}

$\mathrm{Fe}-\mathrm{Zn}$ 合金メッキ材 の Feおよび $\mathrm{Zn}$ の目付 量と光強度積分值の関係 は良好な直線性を示した （Fig.3）。また, 本法 で、一定の範囲内であ れば、Ar压の変動によ る影響も受けにくんのて， 現場ての管理分析手法と しては好適てある。

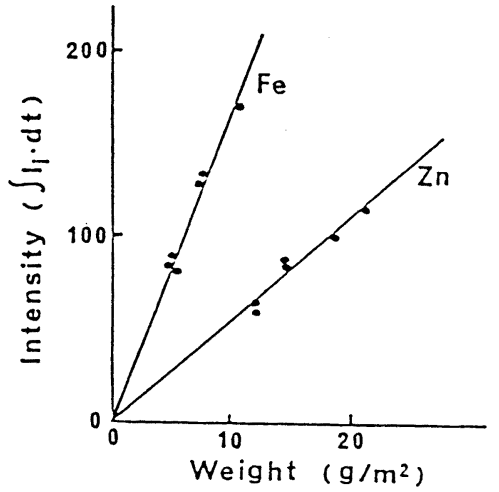

Fig.3 Relationship between GDS intensity and chemical analysis

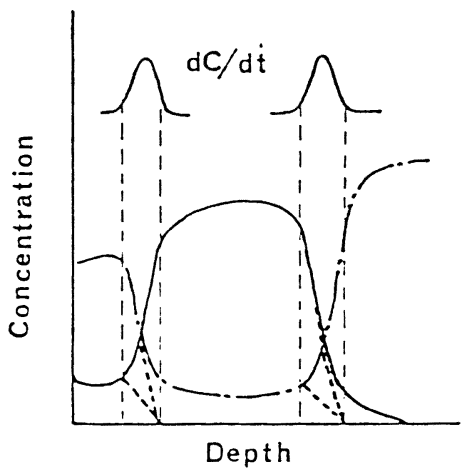

Fig.2 Detection of boundary between layers 
（297）グロー放電発光分光分析法による Fe - Zn 系合金電気めっき屏の分析

日本鋼管怢技術研究所 ○秋吉孝則 岩田英夫 原 富啓 工博 中岡一秀 稲垣淳一 本間俊之

\section{1. 緒 言}

近年, $\mathrm{Fe}-\mathrm{Zn}$ 系合金電気めっき鋼板の開発が進んでいるが，この系のめっき層の分析法は従来法で は種々問題があり適用が困難である。よって哚さ方向分析が可能でスパッタリング速度が大きいグロー 放電発光分光分析法の適用を検討したので報告する。

\section{2. 単層低 $\mathrm{Fe}$ 含有率 $\mathrm{Fe}-\mathrm{Zn}$ 系合金電気めっき層への適用結果}

表 1 のタイプAの系のめっき層への適用を検討した。

(1)分析条件：表 1 のタイプAにこの系での分析条件 を示す。この系では分析条件の設定を若干変化させて も，スパッタリング速度が変化するだけで得られる情 報は殆ど変らない。

(2) Fe 含有率測定：検量線は，化学分析により組成 を求めた電気めっき鋼板を標準試料として用いて作成 する。この系では, グロー放電発光強度值として $\mathrm{Zn}$ 強度値または $\mathrm{Fe}$ 強度の地鉄 $\mathrm{Fe}$ 強度との比を用いる と良好な結果が得られた。測定精度は, 試料のめっき ムラの影響も含めて $5 \%$ 程度であり，分析法の精度と してはCV值 $2 \sim 3 \%$ 程度と推定されるが, 相(phase) の影響を受けるため正確さは悪くなる。

\section{3. 二層 $\mathrm{Fe}-\mathrm{Zn}$ 系合金電気めっき層への適用結果}

Table 1 Analytical conditions

\begin{tabular}{|c|c|c|c|}
\hline & & Type A & Type B \\
\hline \multirow{4}{*}{$\begin{array}{l}\text { Character- } \\
\text { istics } \\
\text { of deposits }\end{array}$} & \multirow{2}{*}{ layer } & \multirow{2}{*}{ single } & Double \\
\hline & & & upper $\quad$ lower \\
\hline & Fe content & $<30 \%$ & $>40 \%$ \\
\hline & $\begin{array}{l}\text { amount of } \\
\text { deposit }\end{array}$ & $>10 \mathrm{~g} / \mathrm{m}^{2}$ & $\leq 5 \mathrm{~g} / \mathrm{m}^{2}>>1$ \\
\hline \multicolumn{2}{|c|}{ Inner diameter of anode } & $8 \mathrm{~mm}$ & $4 \mathrm{~mm}$ \\
\hline \multicolumn{2}{|c|}{ Ar flow rate } & $50 \mathrm{me} / \min$ & $70 \mathrm{~m} \ell / \min$ \\
\hline \multicolumn{2}{|c|}{ Ar pressure } & $130 \mathrm{~Pa}$ & $160 \mathrm{~Pa}$ \\
\hline \multicolumn{2}{|c|}{ Di scharge control } & V. cons $\mathrm{t}$ & V.const \\
\hline \multicolumn{2}{|c|}{ Voltage } & $750 \mathrm{~V}$ & $650 \mathrm{~V}$ \\
\hline \multicolumn{2}{|l|}{ Current } & $65 \sim 80 \mathrm{~mA}$ & $14 \sim 20 \mathrm{~mA}$ \\
\hline \multicolumn{2}{|c|}{ Fe analytical line } & $259.9 \mathrm{~nm}$ & $259.9 \mathrm{~nm}$ \\
\hline \multicolumn{2}{|c|}{$\mathrm{Zn}$ analytical line } & $213.9 \mathrm{~nm}$ & $213.9 \mathrm{~nm}$ \\
\hline \multicolumn{2}{|c|}{ Integration time } & $1 \mathrm{sec}$ & $1 \mathrm{sec}$ \\
\hline \multicolumn{2}{|c|}{ measuring interval } & $1 \mathrm{sec}$ & $1 \mathrm{sec}$ \\
\hline
\end{tabular}

表 1 のタイプBの系への適用を検討した。

(1)分析条件：スパッタリングの均一性を上げるため，表 1 の タイプ Bの条件を採用した。

(2) $\mathrm{Fe}$ 含有率測定 : 高 $\mathrm{Fe}$ 含有率ではスパッタリング速度が 落ちてFe のスパッタリング総量がかえって減るため，Fe 強 度では検量線が得られない。よって $\mathrm{n}$ 強度によって $\mathrm{n}$ 含有 率から逆算して求めることとした。Fe 含有率の深さ方向分析 パターンを図1に示す。この系での $\mathrm{Fe}$ 含有率測定精度は上層 でC V 值 $2 \%$ 程度，下層で C V 值 $5 \%$ 程度であり，単層系で作 成した検量線をそのまま適用できる。

(3)めっき付着量測定 : 付着量測定法としては, 哚さ方向分析 パターンの各層の強度の中間值までのスパッタリング時間と各 層の $\mathrm{Fe}$ 含有率のスパッタリング速度より求める。測定精度は 上下層とも C V 值 $5 \%$ 程度であるが，下層は単層で求めたスパ ッタリング速度をそのまま適用できるのに対し，上層は低值傾 向となり，別途スパッタリング速度を求める必要がある。

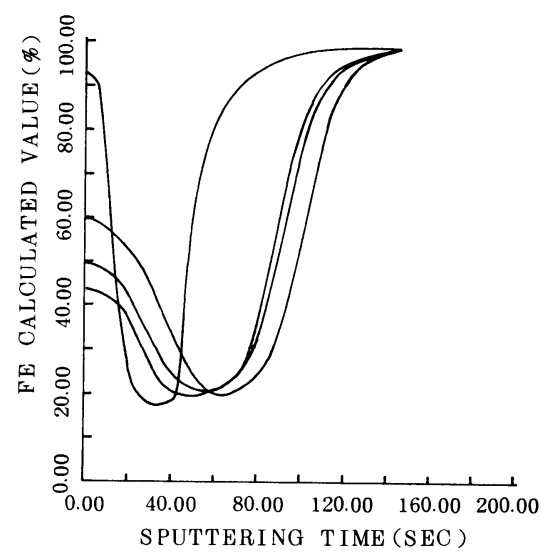

Fig.l Depth profiles of Fe content in electroplated sheet type B by glow discharge source 


\section{1. 緒言}

マトリックス効果が小さく、広い濃度範囲にわたって直線性の良い検量線が得られるといらグロ一放電発光分 析法の特徵を利用して高合金鋼の定量について検討した。高合金鋼の場合はマトリックス濃度が大をく変動する ので、その補正定量法として鉄規準の濃度比法及び前報 ${ }^{1)}$ で報告した全光量 ( Fi ) 規準の強度比法の比較検討を 行なった。またアノードパィプ内径の分析精度への影響、さらにNの定量についても検討を行なった。

\section{2. 実 験}

発光分析装置は前報 ${ }^{1 ）}$ と同様、西独 R S V 社 ANALYMAT2504 を使用した。試料は、J S 、 NBS、JAERI、及 び自社製標準試料在使用した。

\section{3. 実験結果}

(1)アノードパィプ内径：アノードパイプ内径を 8 m øから $4 m$ m さくし、予備放電時間の大幅な短樎が可能となり、Table 1 に示すよ5に分析精度にも任とんど違いが見られないととが わかった。通常、電流密度を高くするとスパッタリング面が 凸になっていく問題を生じるが、このようにアノードパイプ 内径を小さくして高電流密度とした場合には、比較的均一な スパッタリング面が得られた。

（2）規準化法：ステンレス鎕、鉄基耐熱合金、さらにニッケ ル基耐熱合金についても適用を試みたが、検量線に関しては 鉄、全光量いずれの規準化法においても広範囲 にわたって良い直線関係が得られた。全光量規 準の强度比法はマトリックス濃度の変動の影響 を受けず、目的元素だけの検量線で定量でさる という利点があるが、 Table 2 のニッケル基 耐熱合金の分析例から、分析精度、正確さでは 鉄規準の濃度比法が良好な結果を与えることが わかる。

(3) $\mathrm{N}$ 分析：Table 3 はステンレス鉱中の $\mathrm{N}$ の分析結果を示したものである。アノードパイ プ内径を $4 \mathrm{~mm} \varnothing$ と小くし、放電管内の A r 压 を高くしたことにより、大気の影譥をかなり抑 制するととがでをた。

参考文献

1) 岡野, 松村, 針間矢：鉄と鋼 69（1983） S1053
Table 1. Repeatability for stainless steel (X) $n=10$

\begin{tabular}{|c|c|c|c|}
\hline & $\begin{array}{c}\text { Std. } \\
\text { value }\end{array}$ & $\begin{array}{c}4 \mathrm{~mm} \phi \mathrm{a}) \\
\sigma\end{array}$ & $\begin{array}{c}8 \mathrm{~mm} \phi b) \\
\sigma\end{array}$ \\
\hline $\mathrm{C}$ & 0.046 & 0.0010 & 0.0016 \\
\hline $\mathrm{P}$ & 0.028 & 0.0003 & 0.0005 \\
\hline $\mathrm{S}$ & 0.007 & 0.0002 & 0.0002 \\
\hline $\mathrm{Ni}$ & 9.20 & 0.065 & 0.056 \\
\hline $\mathrm{Cr}$ & 18.58 & 0.120 & 0.130 \\
\hline $\mathrm{Al}$ & 0.003 & 0.0001 & 0.0002 \\
\hline
\end{tabular}

a) $100 \mathrm{~mA}$ b) $150 \mathrm{~mA}$
Table 2. Analytical results for high-temperature alloy ( $) \quad n=5$

\begin{tabular}{|c|c|c|c|c|c|}
\hline & Std. & \multicolumn{2}{|c|}{$F_{i}$-method } & \multicolumn{2}{c|}{$F_{e-\text {-method }}$} \\
\cline { 3 - 6 } & value & $\bar{x}$ & $\sigma$ & $\bar{x}$ & $\sigma$ \\
\hline $\mathrm{Ni}$ & 73.8 & 70.48 & 0.634 & 73.85 & 0.052 \\
\hline $\mathrm{Cr}$ & 16.9 & 17.08 & 0.083 & 16.70 & 0.035 \\
\hline $\mathrm{Al}$ & 0.50 & 0.506 & 0.008 & 0.498 & 0.002 \\
\hline $\mathrm{B}$ & 0.0115 & 0.0112 & 0.0005 & 0.0116 & 0.0008 \\
\hline $\mathrm{Nb}$ & 1.22 & 1.16 & 0.015 & 1.21 & 0.005 \\
\hline $\mathrm{Fe}_{\mathrm{nnnyy}}$ & 4.32 & 3.65 & 0.051 & 4.27 & 0.018 \\
\hline
\end{tabular}

Table 3. Analytical results of nitrogen in stainless steels (x) $n=7$

\begin{tabular}{|c|c|c|c|}
\hline Sample & Std.value & $\bar{x}$ & $\sigma$ \\
\hline JSS-652 & 0.016 & 0.0168 & 0.0008 \\
\hline " -654 & 0.026 & 0.0255 & 0.0004 \\
\hline
\end{tabular}




\section{（299）高周波誘導結合プラズマ発光分光分析法における 内標準元素Yに対する共存元素の影響}

\section{大同特殊錀(侏) 中央研究所藤根道彦鈴木敬彦 成田正尚○茂木文吉}

1. 緒言 I C P 分析では、各種の干涉が現われる。目的元素が共存する元素により分光干涉を受ける 場合には、その影響量の補正が、あるいは試料吸上げ時の試料液の粘性などに基づく物理干涉に対して は、Yなどを内標準にした強度比を用いて干涉の影響を除くととが一般に行われている。Yを内標準元 素として用いる場合には、Yは他の共存元素による分光干涉や化学干涉を受けないてとが望ましい。し かし、Yが他の共存元素の影響を受けないという仮定の下に I C P 分析作業を進めると、不都合な場合 に出合うととがある。特に合成溶液を用いて検量線を作成する場合にてのようなケースが多く、共存元 素が $\mathrm{Y}$ 強度にどのような影響をおよはししいるかを知るととは、合成溶液の調整方法などに対して重要

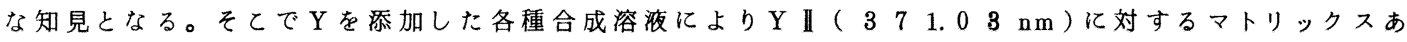
るいは共存元素の影響を調べた。

2. 装置島津製 I C P V - 10000 を用いた。

3. 試料溶夜の調製 $\mathrm{Y}$ 強度変化の影響は、特に有効数字のけ た数の多い高含有成分において顕著であるため、ステンレス銅 などの試料を分解し得る酸分解法を前提にした。マトリックス あるいは共存元素を金属として必要量秤り取り、 $\mathrm{HC} \ell(1+1)$ $20 \mathrm{ml}$ 又は $\mathrm{HNO}_{3} 5 \mathrm{ml}$ で分解し, 混酸 $\left(\mathrm{H}_{2} \mathrm{SO}_{4} 5 \mathrm{ml}, \mathrm{H}_{3} \mathrm{PO}_{4}\right.$ $\left.5 \mathrm{ml}, \mathrm{H}_{2} \mathrm{O} 5 \mathrm{ml}\right)$ で白煙処理後, $\mathrm{Y}$ 溶液 $(1 \mathrm{mg} / \mathrm{ml}) 10 \mathrm{ml}$ 加 えて正確に $100 \mathrm{ml}$ 亿希釈した。

4. 結果ट考察 鉄鋼, 超合金においてマトリックスになり得 る元素である $\mathrm{Fe}, \mathrm{Ni}, \mathrm{Co}, \mathrm{Cr}, \mathrm{Cu}$ の影響を調べた結果の 例をFig. 1 に示す。いずれの元素も $\mathrm{Y}$ 強度を抑制する効果を示 している。ての抑制効果はプラズマの中におけるイオン間の化 学干涉と考えられ、観測高さ，キャリヤガス流量などの条件に より影響の大きさが異る。合成溶液を検量線に用いる場合は、 合成溶液と実際試料のマトリックスをできるだけ正確に合わせ なければならないととがとの例からも判る。

鉄鋼陚料を考えて、 $\mathrm{Fe}-\mathrm{X} 2$ 元系 $(\mathrm{Fe}+\mathrm{X}=0.5 \mathrm{~g})$ 合成溶 夜で共存元素としてのX元素の影響を調べた結果をFig. 2 に示 す。X元素は鋼中に高い含有率で含まれる成分を選択した。共 存元素は $Y$ 強度に影響するが低含有成分に対しては無視できる 程度と思われる。しかし高含有成分においては何らかの配虑を する必要がある。例えば $\mathrm{Fe}-\mathrm{Cr}$ において C r $20 \%$ は $\mathrm{Cr}=$ $0 \% に$ 対して、Y強度が相対的に0.5\%異り、無視してょい大 きさではない。合成溶液を調整する場合、あるいは標準試料を 検量線に用いる場合でも共存元素の量を分析する試料にできる だけ合わせる注意が必要である。

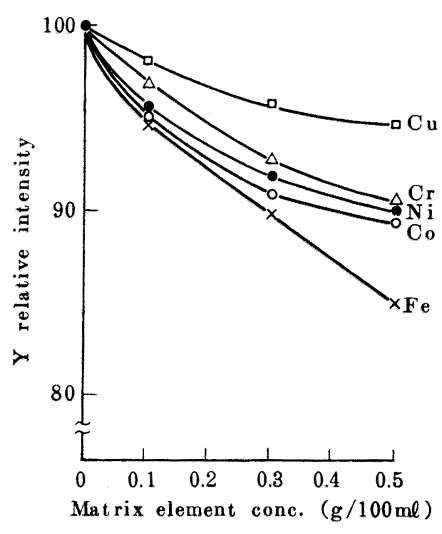

Fig. 1 Effect of matrix element on $\mathrm{Y}$ intensity

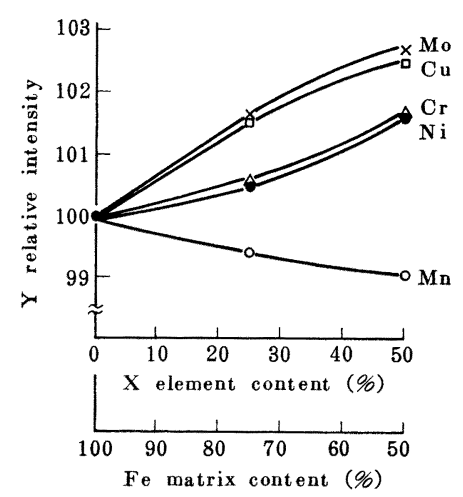

Fig. 2 Effect of co-existing element $(X)$ on $Y$ intensity 
$' 84-\mathrm{S} 300$

\section{（300）高周波誘導結合プラズマ発光分光分析における検量線の一元化と定量下限の向上}

\section{1. 緒 言}

I C P 分析法はその優位性により広い分野で活用されているが、(1)試料溶液の液性、マトリックスなどによって 発光挙動が異古るため、溶液化の方法、分析対象に対応した検量線が必要、(2)塩濃度の高い溶液の連続分析が困 難で試料、融剤の大巾な増量が不可能、などの制約があり応用範囲の拡大や定量下限の向上には限界があった。 そてで最近微少量試料の分析によく用いられているインシェクション法をI C P 分析に適用して高濃度溶液によ る定量下限の向上および検量線の一元化について検討した。

\section{2. 装置および方法}

装置は島津製作所製のI CPS-100V を使用した。をた試料溶液は数十〜 数百 $\mu \ell$ をテフロンカップに滴下しプラズマ中へ吸引噴霧した。

\section{3. 結果およひ考察}

(1)溶液噴霧量と強度測定：微少量の溶液をプラズマ中に噴籍するとシャ ープなピークが現れるが、液量の増加によりブロードになる。また Fig. 1 に示すよらにマトリックス（Fe）濃度が増加すると低くブロードなピーク となる。そてで強度測定は波高あるいはピーク強度ではなく、発光ピーク 全体を積分するとととした。をた容液噴霧量沬再現性が良く、連続噴雱とほ

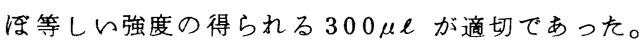

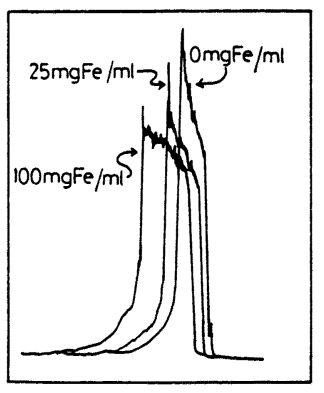

Fig.1 Effect of Fe on signal of $\mathrm{Ni}$

(Sample volume $300 \mu l$ )

(2)酸および $\mathrm{Fe}$ 量の影響：酸はその種類に関保なくモル濃度に従って発 光強度を変化させ、 $\mathrm{Fe}$ 量の増加は $\mathrm{BG}$ の変動や噴霧効率の低下など発光 状態に大さく影䇾を及ほす。いずれの場合もBG 補正で軽隇でをるが、一 定量の噴霧とその全積分測定により影響を解消でさた。Fe 量を変化させ た時の検量線例をFig. 2 に示すが Fe 量に関倸なく一元化が可能であっ た。

(3)微量分析への適用: 試料溶液濃度を従来 $(0.5 \mathrm{~g} / 100 \mathrm{ml})$ の 10 倍と し鉄鋼中微量 $\mathrm{P}$ 分析に適用した結果を Table 1 亿示す。検量線は Fe を共 存させず $\mathrm{KH}_{2} \mathrm{PO}_{4}$ 水溶液のみで作成したが、標準值とよく一致し精度も 良好であった。

これらの結果は微少かつ一定量の噴霧と発光ピークの全積分により液性、

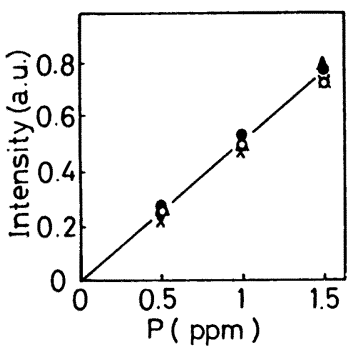

Fig.2 Effect of Fe on calibration curve for PI $178.29 \mathrm{~nm}$

(B.G. Corrected)

- $0 \mathrm{mgFe} / \mathrm{ml} \bullet 20 \mathrm{mgFe} / \mathrm{ml}$

A $50 \mathrm{mgFe} / \mathrm{ml} \times 100 \mathrm{mgFe} / \mathrm{ml}$

マトリックスによる吸上量変動などの物理的影繁が解消でをたとと、また

試料量の増加により定量下限が向上したためで ある。

\section{4. 結 言}

本法は高濃度溶液の分析、検量線の一元化が 可能で、瀜剤を多量に使用する粉体分析など適 用範囲の払大に有効であるととを示唆した。 参考文献：1) J. G. Shabushnig, G. M. Mief tje :

Table 1 Analytical result of $P$ in steel (ppm)

\begin{tabular}{|c|c|c|c|c|c|c|c|}
\hline \multirow{2}{*}{ Sample } & \multirow{2}{*}{$\begin{array}{c}\text { Chem } \\
\text { Value }\end{array}$} & \multicolumn{3}{|c|}{ Injection method } & \multicolumn{3}{|c|}{ Routine method } \\
\cline { 3 - 8 } & $\overline{\mathrm{X}}$ & $\sigma$ & $\mathrm{CV}(\%)$ & $\overline{\mathrm{X}}$ & $\sigma$ & $\mathrm{CV}(\%)$ \\
\hline $\mathrm{A}$ & 5 & 4.8 & 0.26 & 5.44 & 5 & 1.5 & 30.9 \\
\hline $\mathrm{B}$ & 10 & 9.4 & 0.21 & 2.19 & 15 & 2.8 & 18.3 \\
\hline $\mathrm{C}$ & 11 & 10.8 & 1.33 & 12.28 & 18 & 3.4 & 20.7 \\
\hline $\mathrm{D}$ & 20 & 20.3 & 0.70 & 3.43 & 23 & 2.3 & 10.0 \\
\hline
\end{tabular}
Anal. Ch im. Acta, 148, 181(1981) 2) P. W. Alexdnder, R. J. Finlayson, L. E. Smythe, A. Thalib, :Analyst, 107, 1335(1982) 
（301）溶媒抽出による高周波プラズマ発光分光分析

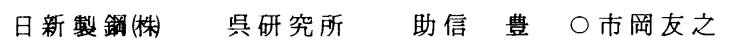

田中清之

I. 緒 言

近年鉄鋼材料の研究は、微量不純物をできるだけ取り除き、高品質化を図る傾向にあるが、必ずしも 極㽔量の分析は、精度面において満足するものではない。

前回、鉄鋼の分析として、酸溶解法による銅中P（20 500 p p m) の分析を報告 ${ }^{1}$ したが、今回、有機

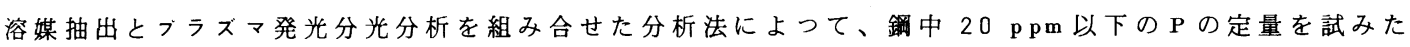
ので、その結果を報告する。

I. 実験装置

島津 I CPV-1000（真空型分光器）

1. 実験結果

1）発光条件の検討有機溶媒のブラズ、発光は、水 溶液の場合と比較して、トーチの点火条件が重要である。 したがって、高周波出力、キャリ十カス流量、光源の位置 などの条件について検討した。主な条件である、キャリヤ ガス流量と発光強度の関係を求めた結果を図1に示した。

2）抽出条件の検討 M I BK 中へのP の抽出度と硝酸 濃度との関係を求めた結果を眓 2 に示した。低硝酸濃度で は、未反応のPも抽出することを示し、安定するためには $2.9 \mathrm{~N}$ 以上の濃度が必要であることを示している。

微量のPをモリブデン酸アンモニゥムの錯体にするため のモリプデン酸の添加量や、MIBKに完全に抽出させる諸 条件を決定した。

検量線は、リン酸ーカリゥムを標準物質として作成した。 その一例を図了に示した。

共存元素として、 $\mathrm{Ni}, \mathrm{Cr}, \mathrm{Mn}$ は抽出液中 $20 \mathrm{mg}$ (鋼中 2

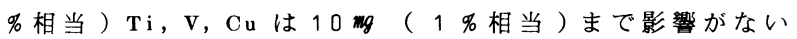
ことを確認した。

本法で鉄鋼標準試料と社内標準試料を分析し、その結果 を表1に示した。 能であつた。

\begin{tabular}{|c|c|c|c|c|}
\hline \multirow{2}{*}{$\begin{array}{l}\text { Standerd } \\
\text { Bemple }\end{array}$} & BCS $088-1$ & JSS $001-1$ & Nxss 145 & NKSS 146 \\
\hline & $42 \mathrm{ppm}$ & $12 \mathrm{ppm}$ & (2 $\mathrm{ppm})$ & (2 $\mathrm{ppm})$ \\
\hline$\overline{\mathbf{x}}$ & 39.7 & 12.4 & 2.09 & 1.67 \\
\hline - & 1.87 & 1.37 & 0.14 & 0.22 \\
\hline $\operatorname{cr}(x)$ & 4.71 & 11.06 & 6.91 & 13.67 \\
\hline
\end{tabular}

1）森田, 田中, 市岡, 鉄と鋼67（1981）s 1092

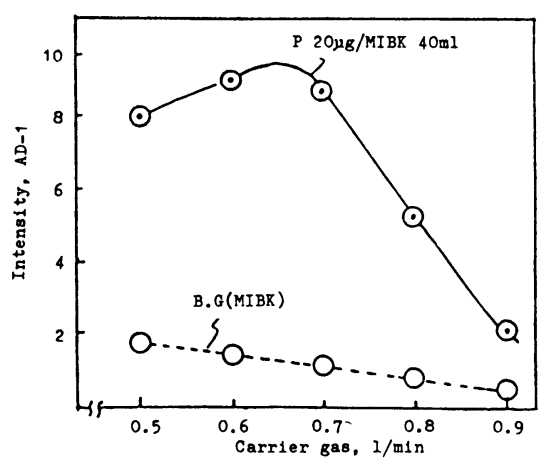

P1g. I Effect of carrier gas on emision intensity

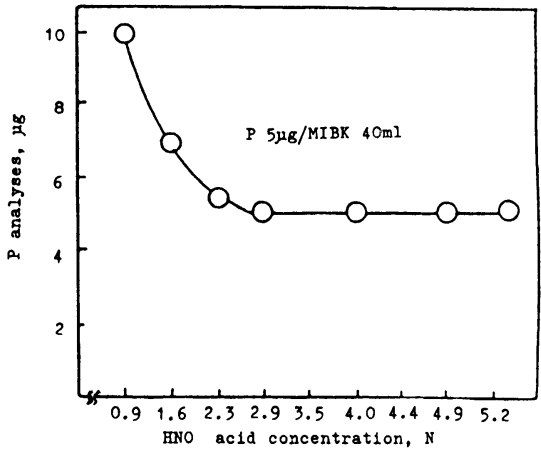

Pig. 2 Effect of HNO acid conchtration on $P$ analyses

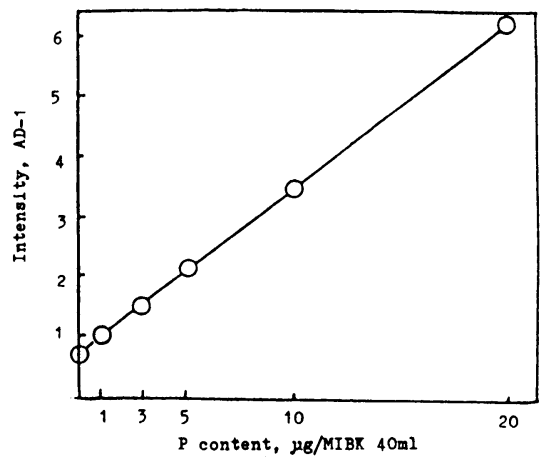

P1g. 3 Calibration curve. for $P$ in steel 
' $84-\mathrm{S} 302$

スパーク放電条件および定量精度の検討

（超微粒子生成ープラズマ発光分光法による鉄鋼分析一1）

新日本製鐵(株) 第一技術研究所。小野昭紘 佐伯正夫

\section{1. 緒 言}

溶液試料を対象とする通常のI C P 発光分光分析法は, 定量感度・精度, 定量範囲の広さなどに特長 をるつために鉄鋼分析に活用されている。しかし，固体試料を直接 I C P 分析する技術の開発は，分析 操作の簡易・迅速化および高感度化に寄与し, あるいは素材, 製品の鋼種判定など製造現場での非破壊 迅速分析手法として役立つ。そてで, 低圧スパーク放電を蒸発源として生成した鋼試料の超微粒子をI C Pのブラズマ中へ導入する超微粒子生成ープラズマ発光分光分析法（UFP-ICP) につレて検討した。 本報告では，U F P 生成のスパーク放電条件小よび各元素の定量精度を中心に調べた。

\section{2. 実験方法}

分析装置および分析条件をTable.1亿示した。固体試料（J S S $162 \sim 167$ などの低合金鋼 8 種) 亿放電定数を変えた低圧スパーク 放電（スパークおよびアーク）を行ってU F P を生成し，小型サイ クロンを経て I C P フプラズマ中に導入し, 各スペクトル線強度を 測定し，各元素の定量精度を求めた。

\section{3. 実験結果}

（1）超微粒子生成スパーク放電条件 スパークおよびアーク放 電 (Table. 1) を用いて測定した各元素の定量精度 (Fe内標準法) をTable.2 亿示した。いずれの元素とす精度はスパークがすぐれ， 安定したU F P の生成にはアークよりるスパークの方が適している。

(2) 検 量 線 Fig.2 亿一例を示した。 P, S, Si, Mn, $\mathrm{Cu}, \mathrm{Ni}, \mathrm{Cr}, \mathrm{Al}, \mathrm{Ti}, \mathrm{B}$ なと $\mathrm{C}$ 以外の元素につんては, 直線性の 良好な検量線が得られた。Cについてはバックグランドの低下など 改善の余地がある。

（3）定量精度・感度 定量精度につんては, U F P 生成のため の適切な放電定数の選択および $\mathrm{Fe}$ 内標準法の採用により，いずれ の元素とも C.V. 5 \% 以内の良好な精度が得られた。定量感度につん ても同様で, C以外の各元素は通常の固体発光分光分析法に比べて ほほ同程度の感度が得られた。

\section{Table.2 Roproducibility}

\begin{tabular}{|c|c|c|c|c|c|c|c|c|c|c|c|}
\hline $\begin{array}{l}\text { Analytical } \\
\text { line (nm) }\end{array}$ & $\begin{array}{l}\text { Discharge } \\
\text { condition }\end{array}$ & c. v. & $\begin{array}{c}\text { B.E.C.: } \\
\text { (\%) }\end{array}$ & $\begin{array}{l}\text { Analytical } \\
\text { line }(\mathrm{nm})\end{array}$ & $\begin{array}{l}\text { Discharge } \\
\text { condi tion }\end{array}$ & $\begin{array}{l}\text { c. v. } \\
\text { (\%) }\end{array}$ & $\begin{array}{c}\text { B.E.c. } \\
\text { (\%) }\end{array}$ & $\begin{array}{l}\text { Ansalytical } \\
\text { line ( }(n m)\end{array}$ & $\begin{array}{l}\text { Discharge } \\
\text { condition }\end{array}$ & $\begin{array}{l}\text { c. v. } \\
\text { (क) }\end{array}$ & $\begin{array}{c}\text { B. E.C. } \\
\text { (क) }\end{array}$ \\
\hline \multirow{2}{*}{$\begin{array}{c}c \\
1165.8 \\
(0.19 \%)\end{array}$} & Spark & 4.7 & - & \multirow{2}{*}{$\begin{array}{c}S i \\
1251.6 \\
(0.21 \%)\end{array}$} & Sperk & 1.4 & 0.04 & \multirow{2}{*}{$\begin{array}{c}\mathrm{Cu} \\
1327.4 \\
(0.10 \%)\end{array}$} & Spark & 2.1 & 0.005 \\
\hline & Arc & 18.2 & - & & Are & 4.7 & 0.03 & & Are & 3.6 & 0.010 \\
\hline \multirow{2}{*}{$\begin{array}{c}P \\
1,178.3 \\
(0.018 \%)\end{array}$} & Spark & 2.7 & 0.03 & \multirow{2}{*}{$\begin{array}{c}\mathrm{Mn} \\
1257.6 \\
(0.57 \%)\end{array}$} & Spperk & 0.93 & 0.03 & \multirow{2}{*}{$\begin{array}{c}\hat{A l} \\
1 \quad 396.2 \\
(0.0264)\end{array}$} & Sperk & 3.2 & 0.03 \\
\hline & Arc & 9.0 & 0.03 & & Arc & 3.1 & 0.09 & & Arc & 2.9 & 0.04 \\
\hline \multirow{2}{*}{$\begin{array}{c}s \\
1 \quad 180.7 \\
(0.018 \%) \\
\end{array}$} & Spark & 5.8 & 0.01 & \multirow{2}{*}{$\begin{array}{c}C r \\
1267.7 \\
(0.30 \%)\end{array}$} & Spark & 3.7 & 0.18 & \multirow{2}{*}{$\begin{array}{c}\text { B } \\
1 \quad 182.6 \\
(0.0061 \%)\end{array}$} & Sperk & 1.7 & 0.0084 \\
\hline & Arc & 10.2 & 0.01 & & Are & 3.8 & 0.18 & & Arc & 6.3 & 0.0096 \\
\hline
\end{tabular}

- Coefficient of Variation $(n=5)$

.. Background Equivalent Content
Tablo.1 Instrumonts and operating conditions

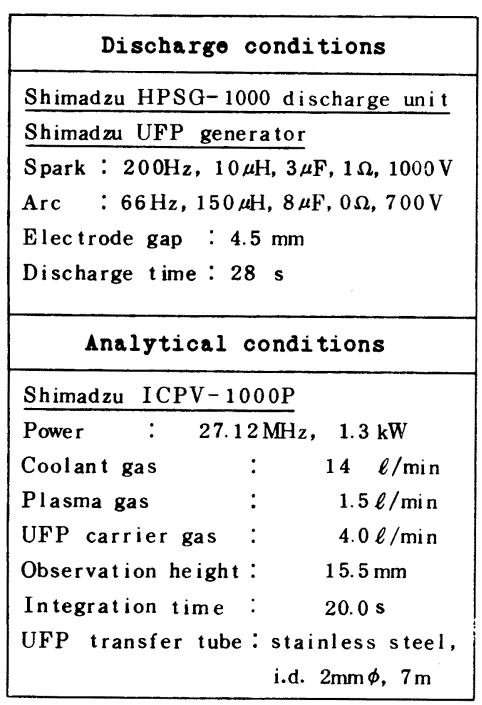

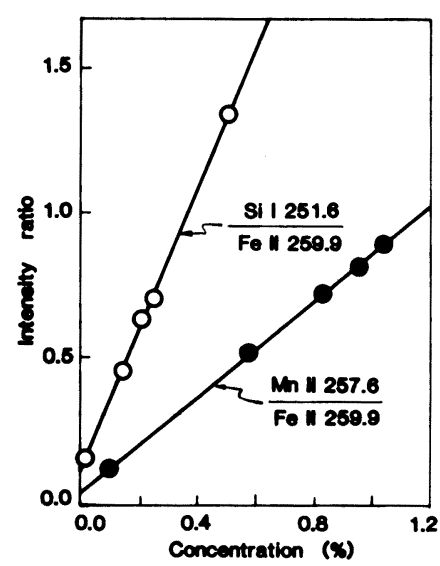

Fig. 1 Calibration curvos 
佐伯正夫

\section{1. 緒 言}

現在, I C P 発光分光法は高感度, 高精度, 広い検量範囲を有するととから, 鉄鋼分析の分野でも溶 液試料の分析法として㕕く用いられている。しかし, 鉄鋼中の炭素の分析に対して溶液 I C P 発光分光 法を商用するととは, 試料の溶液化および感度の面から問題があり, 実際に適用された例は渒とんどな ら。そとで,スパーク放電を固体試料の蒸発源として生成した試料の超微粒子をI C P R導入する 超微粒子生成 -プラズマ発光分光法 (UFP - I C P ) を用いて, 鉄鋼中炭素の直接分析について検討した。

\section{2. 実験方法}

I C P 発光分光装置およびスパーク放電用電源には島津製作所製 I C P V-1000P およびHPS G-1000 を用い，I C P とスパーク放電装置とは内径 $2 \mathrm{~mm} \phi$, 長さ $7 \mathrm{~m}$ のステンレス管で接続した。各装置の実 験条件は Table 1 亿示した。分析用試料には炭素鋼標準試料 ( J S S 162 164), 銑鉄標準試料 (White Cast BS 1〜7)などを用いた。

\section{3. 実験結果}

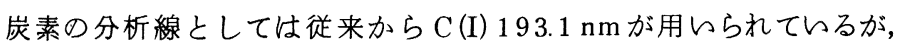
最近の固体発光分析ではC (I) $165.8 \mathrm{~nm}$ が使用されはじめている。そ てで，ICPを光源とした場合のC (I) $193.1 \mathrm{~nm}$ おびC(I) $165.8 \mathrm{~nm}$ の 発光スペクトルについて検討した。まず，溶液 I C P を用いて各分析 波長の近傍につらて炭素, 鉄およびバッククラウンドの発光スペクトルを 観測した。C(I) $193.1 \mathrm{~nm}$ の近傍では炭素に基づく発光線だけしか観測 されず，また，実際の分析上で特に問題となるような妨害元素る見いだ せない。てれに対し，Fig.1で示したょらに，C(I)165.8nmの近傍では

Table.1 Operating Conditions I C P : Coolant Gas $\quad 14 \quad \ell / \mathrm{min}$ Plasma Gas $\quad 1.5 \mathrm{\ell} / \mathrm{min}$ Observation Height $15 \mathrm{~mm}$ RF Power $1.4 \mathrm{~kW}$ Discharge : Electrode Gap $\quad 4.5 \mathrm{~mm}$ Carrier Gas $\quad 3.0 \mathrm{\ell} / \mathrm{min}$ Preflush and Cyclon Gas $\quad 6.0 \mathrm{~B} / \mathrm{min}$ Preburn Time Integration Time $20 \mathrm{~s}$ Discharge Paramator $200 \mathrm{~Hz}$ $1000 \mathrm{~V}$ $\begin{array}{rr}10 & \mu \mathrm{H} \\ 3 & \mu \mathrm{F}\end{array}$ $1 \Omega$ C(I) $165.8 \mathrm{~nm}$ と汪とんど重なる位置に Fe の発光線が観測された。このため, この波長を用いるI C P で の鉄鋼中炭素の分析は非常に困難である。しかしながら, Fig.1のスペクトルにはC (I) $165.7 \mathrm{~nm}$ の強 い発光線も観測されており，乙の発光線を用いれば真空紫外領域での炭素の分析が可能である。

次に，炭素鋼標準試料などを用いて，C(I) 193.1 $\mathrm{nm}$ 拈よび C(I) $165.7 \mathrm{~nm}$ を分析線として, UF P 一 I C P よる炭素の検量線を作成した。どち らの分析線でも， $0.03 \%$ から $0.5 \%$ の範囲で 直線性のよい検量線が得られた。感度の面では C(I) $165.7 \mathrm{~nm}$ の方が若干優れていると思われるが, UFP-ICP では炭素のブランク発光が高いため に，BECなどによる戦密な比較はできない。また， C(I) $165.8 \mathrm{~nm}$ の発光線では, 上述のょらK, Feの 強ら分光干涉を受けるために，得られるシグナルは $\mathrm{Fe}$ の蒸発量に依存し, 検量線の作成は困難であった。 このように, UFP-ICP では鉄鋼中炭素を $0.03 \%$ 以下をで直接分析するてとがでをる。

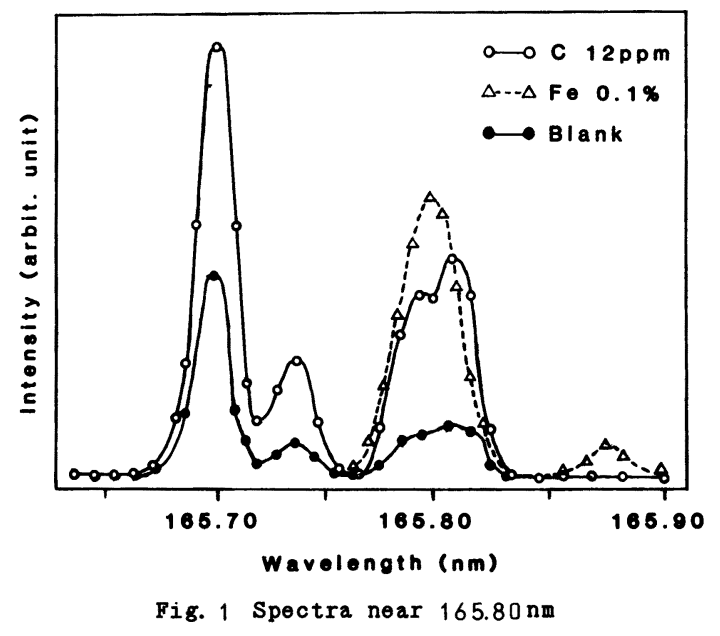

